\title{
مسؤولية البناك الناشئة عن عقد تحصيل الأوراق التجارية
}

\author{
دكتورة \\ رحاب محمود داخلي علي دكي \\ أستاذ مساعد القانون التجاري \\ كليه الحقوق - جامعة طيبة ـ المملكة العربية السعودية
}





\section{المقدهة}

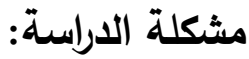

تكمن مشكلة الدراسة في محاولة التعرف على الإطار القانوني

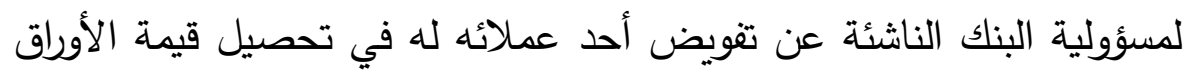

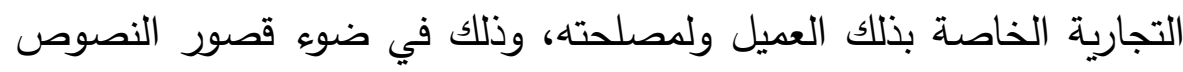
القانونية المنظمة لعمليه تحصيل الأوراق التجارية.

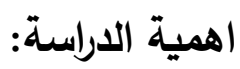

تحاول هذا الدراسة بإيجاز القاء الضوء علي اهميه عمليه تحصيل

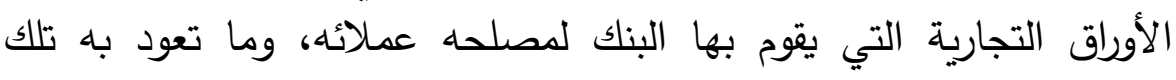

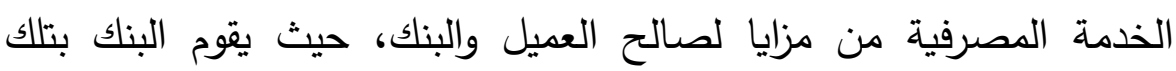

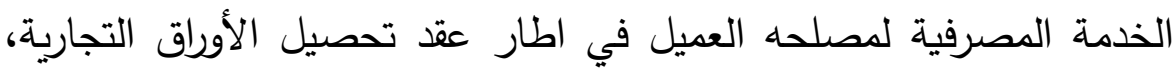

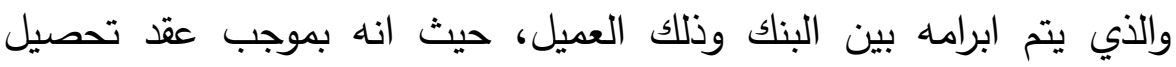

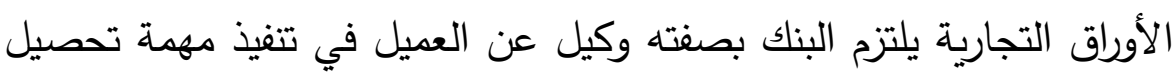

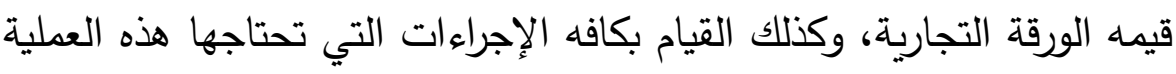

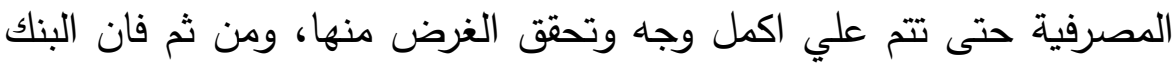

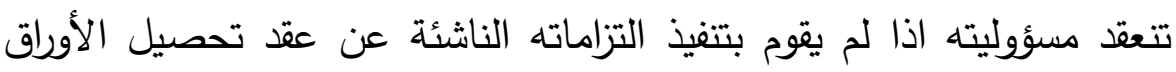

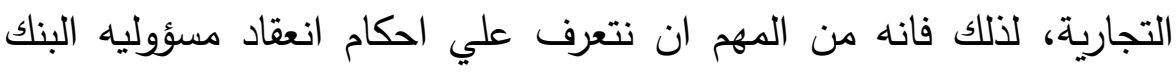

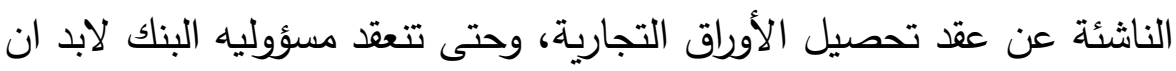

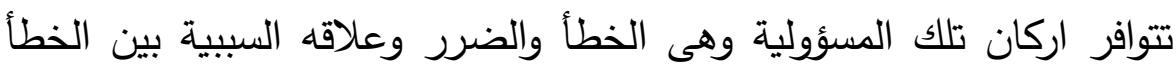

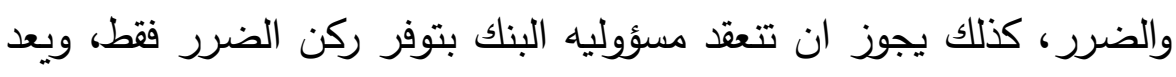

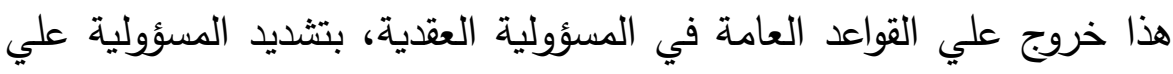

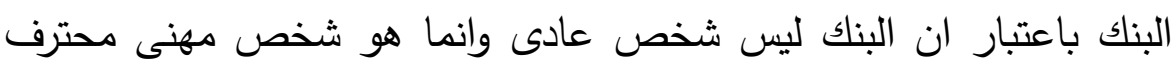

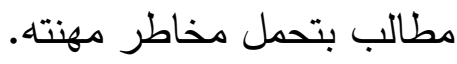

كذلك سوف نحاول من خلال دراستنا التعرف علي احكام اعفاء البناك

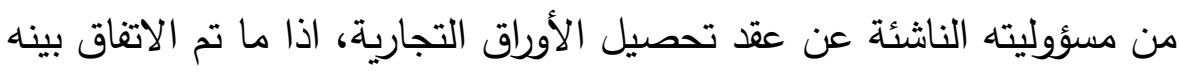

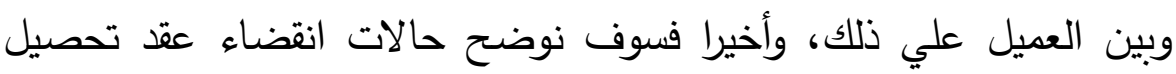

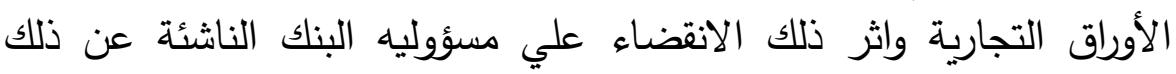
العقد. 


\section{اهداف الاراسة:}

- محاولة الوقوف بإيجاز على طبيعة ونطاق مسؤولية البنك الناشئة عن عقد تحصيل الأوراق التجارية لمصلحه عملائه.

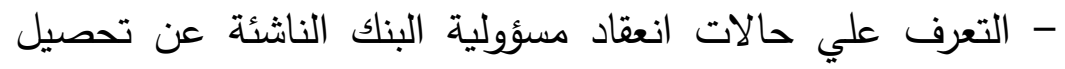

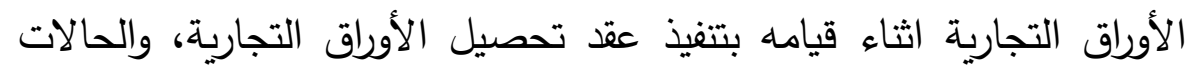
التي يجوز فيها اعفاء البنك من تلك المسؤولية. منهج الاراسة:

اتبعت الدراسة المنهج الوصفي، وذلك من خلال رصد ابعاد المشكلة

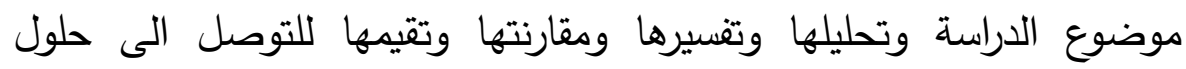
محددة ودقيقة لتحقيق الهدف المنشود من الدراسة. خطة الدراسة:

ولتحقيق أهداف البحث تم تقسيم خطة الدراسة في هذا الموضوع على النحو التالي:

المبحث الاول: المقصود بعمليه تحصيل الأوراق التجارية وطبيعتها. المبحث الثاني: طبيعة مسؤولية البنك في عقد تحصيل الأوليه الأوراق التجارية واركانها.

المبحث الثالث: حالات انعقاد مسؤولية البنك الناتجة عن عقد تحصيل الأوراق التجارية والاعفاء منها. المبحث الرابع: انقضاء عقد تحصيل الأوراق التجارية واثرة علي مسؤولية البنك.

\section{الابحش الأون \\ الاقمود بممليه تمصيل الأوداق التجارية وطبيـتها \\ تمهيد وتقسين.}

نتناول في ذلك المبحث التعرف على ماهية عملية تحصيل الأوراق التجارية، والتي لا تخرج في اطارها العام عن كونها وسيله من وسائل تحصيل 
الحقوق المالية التجارية التي يقدمها البنك كخدمة مصرفية لعملائه، وبالطبع فأنها تعود بالنفع والفائدة علي البنك والعميل مالك الورقة التئة التجارية معًا (المطلب الأول)، كذلك يتطرق بنا الحديث عن توضيح الطبيعة القانونية

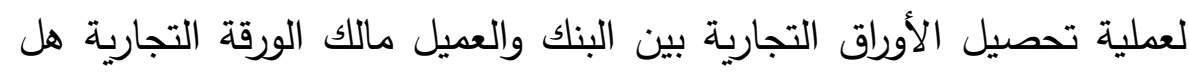

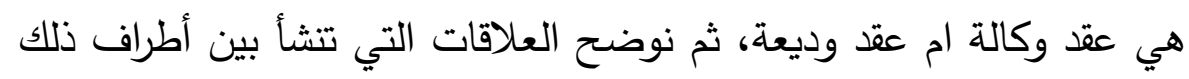
العقد (المطلب الثاني).

\section{الإطاب الأول \\ هاهية عملية تصهيل الأوراق التجارية وهزاياها}

سوف نتعرف اولاً على المفهوم الذي تتم في اطارة عملية تحصيل الأوراق التجارية (اولاً)، ثم نوضح مزايا تلك العملية بالنسبة للبنك والعميل مالك الورقة التجارية (ثانيًا).

\section{اولاً: ماهية عملية تحصيل الأولق التجارية.}

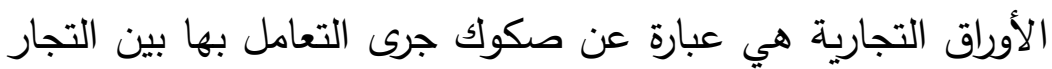

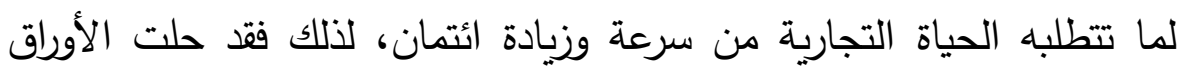

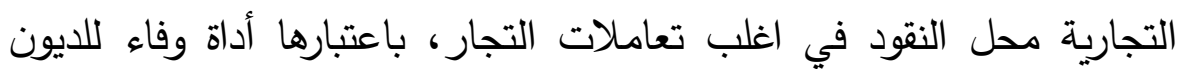

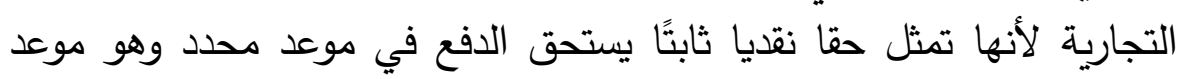

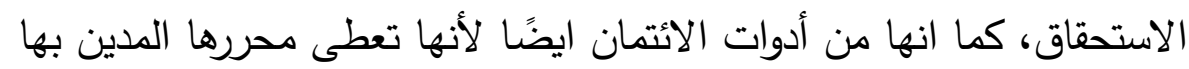

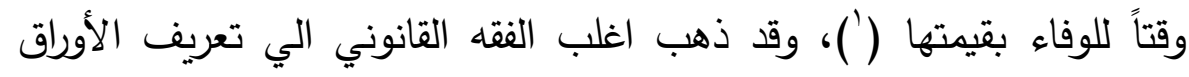

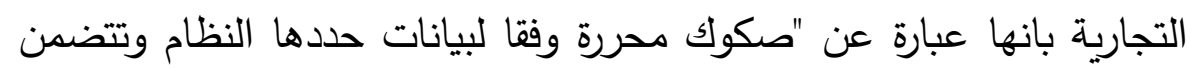

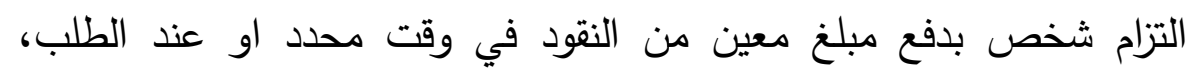
ويمكن نقل الحق الثابت فيها عن طريق التظهير أو المناولة".

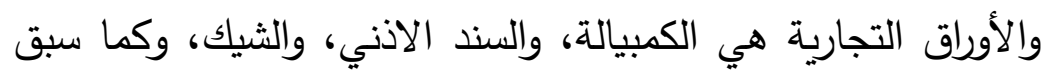

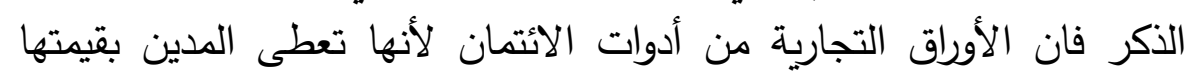

Hamel, Joseph, Banques et opérations de banque. Tome second. Les dépôts et les virements. Les crédits de banque et leurs suretés. Les opérations sur effets de commerce, l'escompte. Aperçu sur le nouveau statut des banques françaisesm. Paris. 1962. p.174. 
اجلاً للوفاء بها، لذلك فان الدائن عليه تحصيل قيمه الورقة التجارية في موعد استحقاقها عند حلول ذلك الاجل، وله في سبيل ذلك ان يُحصل قيمتها بنفسه

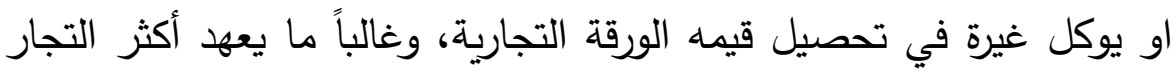
في توكيل أحد البنوك لتحصيل قيمه الورقة التجارية، سواء كانت الورقة

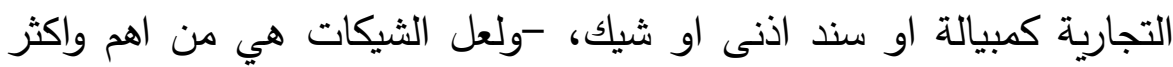

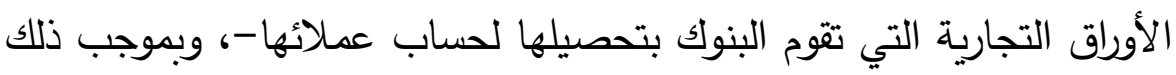
التقويض او التوكيل من العميل، يكون البنك هو المسؤول عن تحصيل قيمه

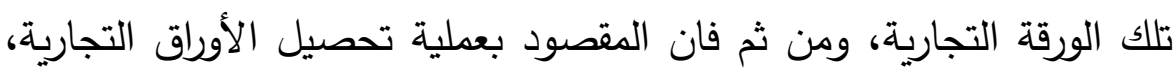

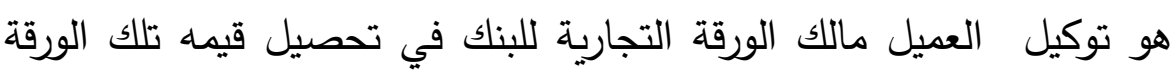

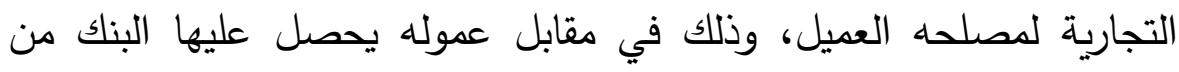

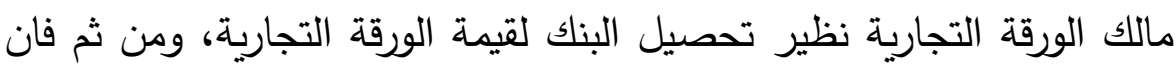

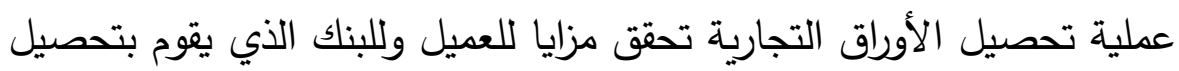
قيمة تلك الورقة.

\section{ثانيًا: مزايا عملية تحصيل الأورلق التجارية.}

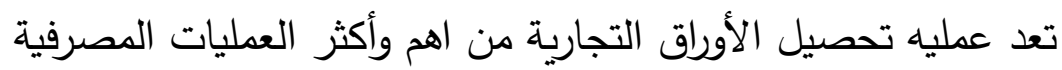
التي تؤديها البنوك لعملائها وذلك لما توفره تلك الخدمة المصرفية من مزايا لأطرافها سواء كان البنك او العميل. (أ) مزايا عملية تحصيل قيمه الأولق التجارية بالنسبة للبن البنك.

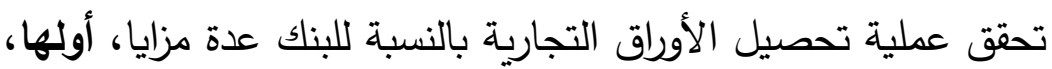

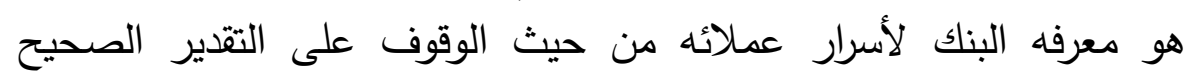
والحقيقي لمركزهم المالي، ومن ثم النظر في مدى منح البنك لهؤلاء العملاء

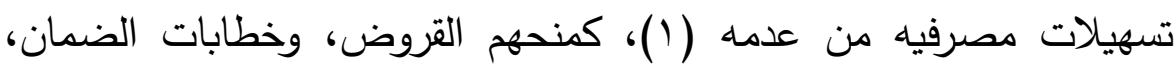

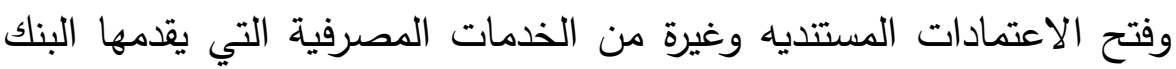

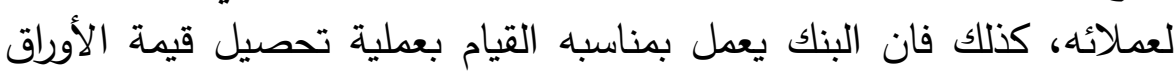

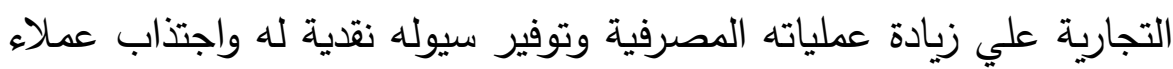

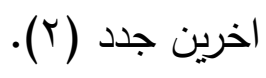

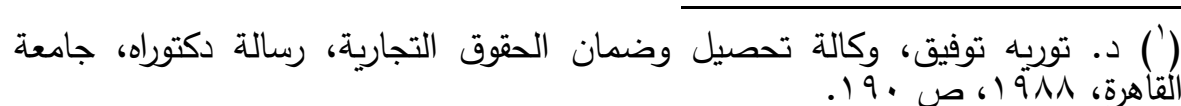

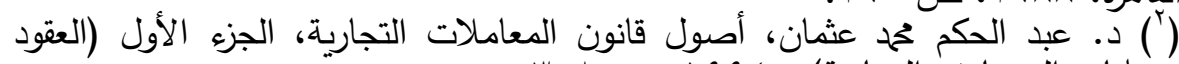

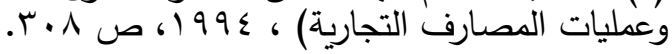


ثانيًا، ايضًا تعود عملية تحصيل الأوراق التجارية بمزايا معنويه ومادية

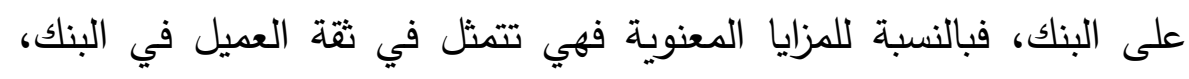

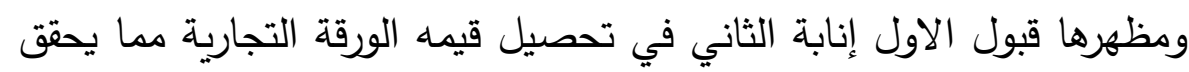
السمعة الطيبة للبنك والتي يسعى كذلك اليها البنك دومًا، اما المزايا المادية

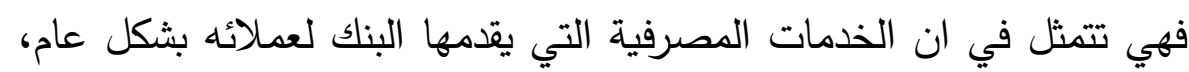

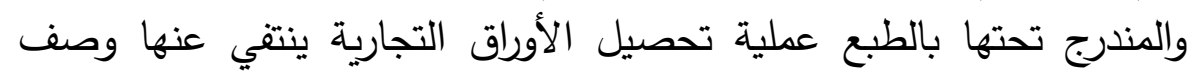
التبرع، لذلك فان البنك يتقاضى عموله من العميل نظير الخدمة المصرفية

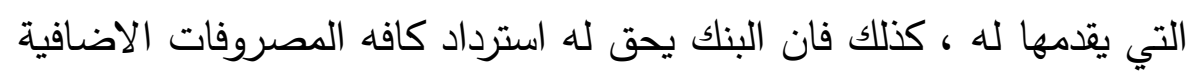
التي قد يتكبدها عند قيامه بتحصيل قيمه الورقة التجارية من العميل (1) (1)،

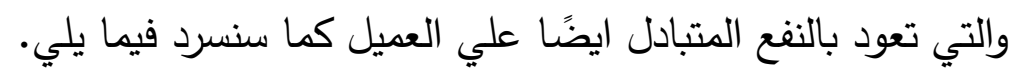

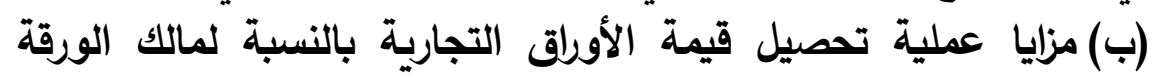
التجاريـة.

كذلك يترتب علي تفويض مالك الورقة التجارية للبنك في تحصيل قيمتها عدة فوائد ومزايا بالنسبة لذلك المالك، حيث يوتي دوفر البنك علي العميل

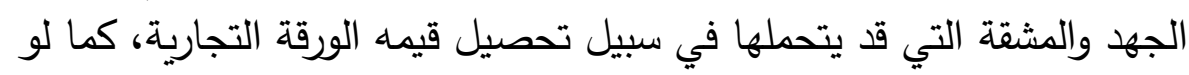
كان موطن المسحوب عليه القابل بعيد عن موطن الحامل الثرعي للورقة التجارية او مالكها، كذلك الامر في حالة تعدد الأوراق التجارية التي يملكها

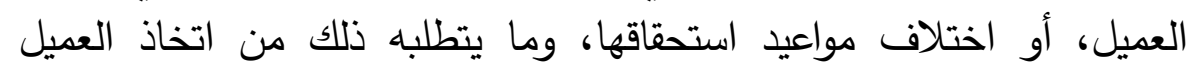

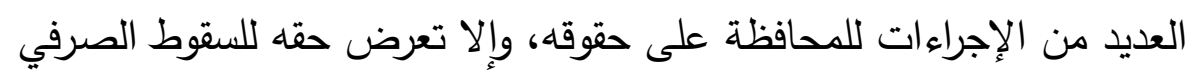

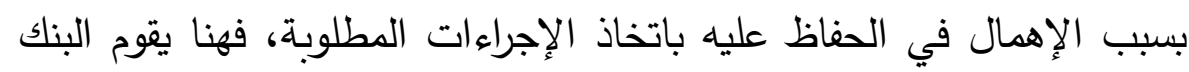
بما يملكه من إمكانيات كبيرة ووسائل متعددة تساعده في تحصيل قيمه الورقة

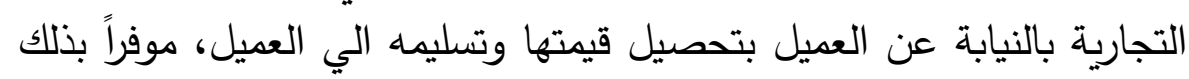

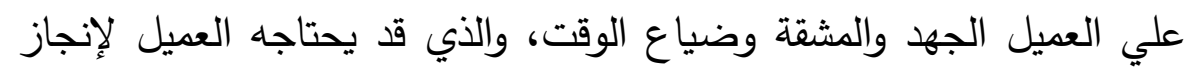

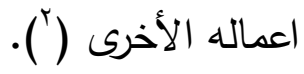

(') د. محمود الكيلاني، الموسوعة التجارية والمصرفية (الأوراق التجارية) دراسة مقارنه، $\left.{ }^{2}\right)$ Hamel, Joseph, Op.cit . p.179. 
كذلك فان البنك يعد شخصي مهنى محترف، يقوم يوميًا بالعديد من

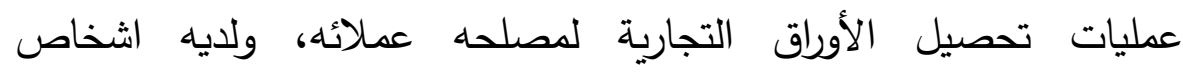
متخصصون في القيام بذلك، وعلى معرفه كافيه بكافة الجوانب القانونية

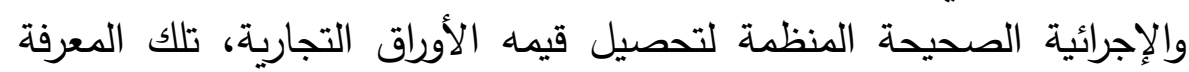
التي قد لا تتوفر لدى العميل مما يترتب عليه في بعض الأحيان ضياع حقوقه الأنها

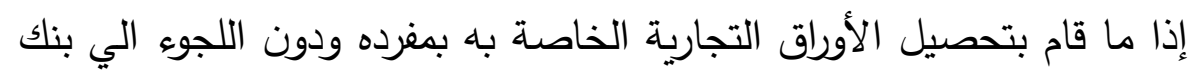
مهنى متخصص في عمليه تحصيل الأوراق التجارية.

\section{الاطلب الثاني الني}

\section{الطبيعة القانونية لعملية تمصيل الأوراق التجارية}

سوف نوضح في ذلك المطلب طبيعة عمليه تحصيل الأوراق التجارية وتكييفها من حيث كونها عقد وكالة تجارية ام عقد وديعة (اولاً)، وبالتالي نستطيع توضيح أطراف ذلك العقد وما ينشأ بينهم من علاقات التات (ثانيًا). اولاً: تكيف العلاقة بين البنك وإلعميل في عمليه تحصيل الأوراق

التجاربـة.

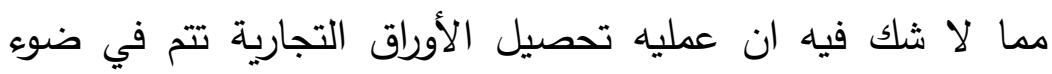
الإطار النمطي العقدي المصرفي كسائر عمليات البنوك الأخرى، فقيام البنك التك

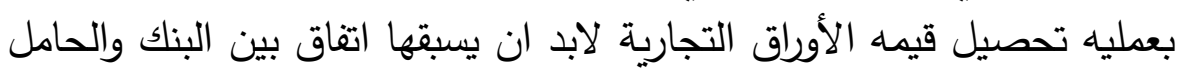

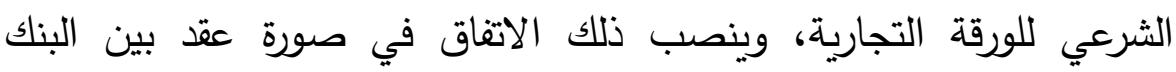

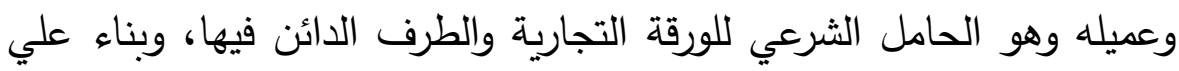

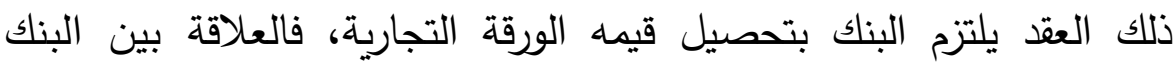

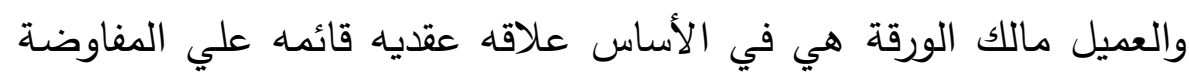

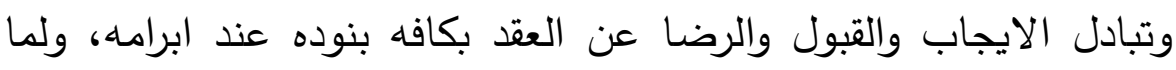

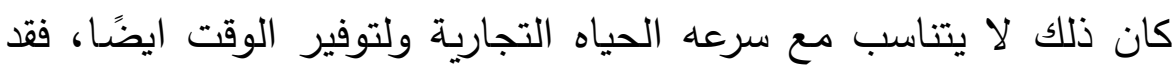
اتجهت كافه البنوك الي اعداد نماذج نمطيه لجميع اشكال العقود والخدمات المصرفية التي تقدمها للعميل بحيث يتم التفاوض من قبل العبل

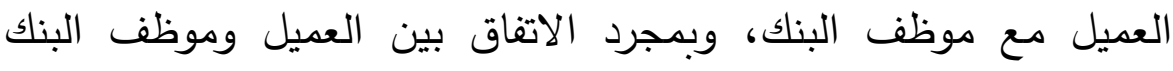
المختص يكون نموذج العقد جاهز لتوقيع العميل بعد تمكين العميل من لين لين لينيل 
الاطلاع عليه بالطبع(')، وبذات الكيفية يتم ابرام عقد تحصيل الأوراق

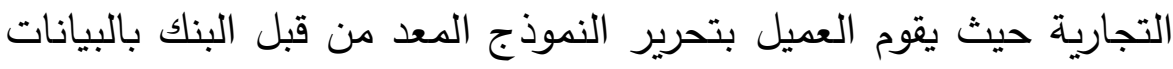

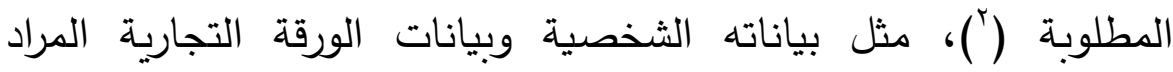

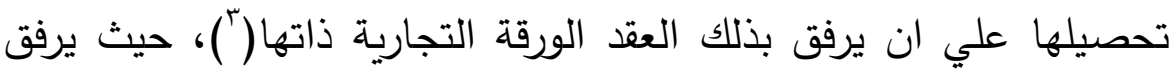

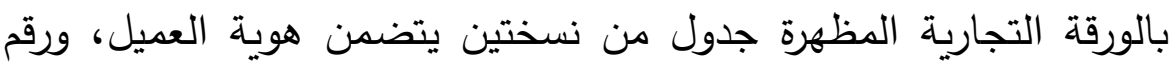

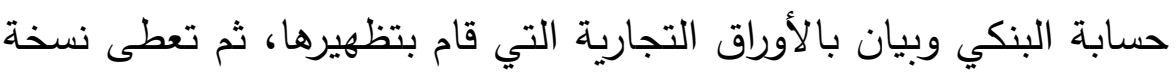

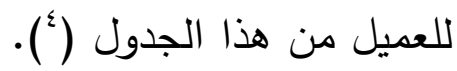
وإذا ما انتهينا الي ان العلاقة بين البنك وعميله مالك الورقة

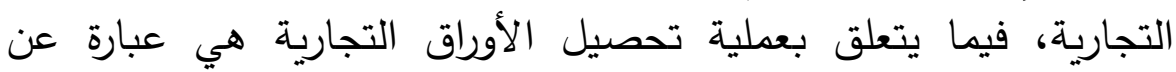
علاقة عقدية، فان علينا معرفه نوع ذلك العقد واحكامه حتى يتثنى لنا لتافيه معرفه وتحديد نوع المسؤولية التي ستقع على البنك، والصفة التي سيقوم علي أساسها البنك بتحصيل قيمة الورقة التجارية. لم يثور جدل فقهى حول تكيف العلاقة بين البنك ومالك الورقة لتهاه

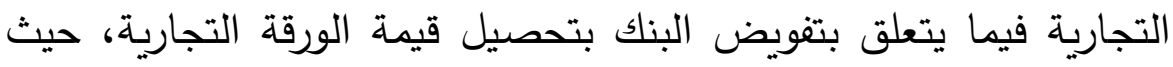
ذهب اغلب الفقه الي تكييف العقد بين البنك والعميل على انه عقد وكالة

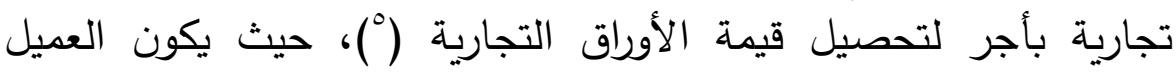

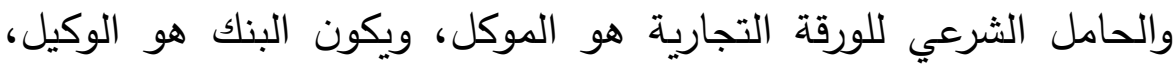
ومحل عقد الوكالة هنا هو تحصيل قيمه الورقة التجارية، ومن ثم يلجأ

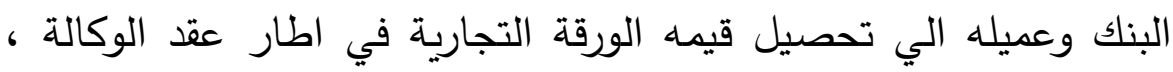
(') د. محمد السيد الفقي، القانون التجاري (الإفلاس وعمليات البنوك) منشورات الحلبي

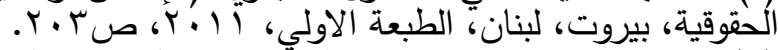

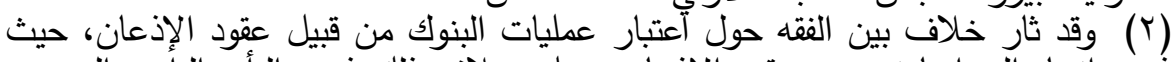

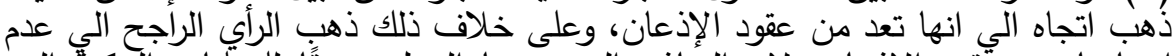

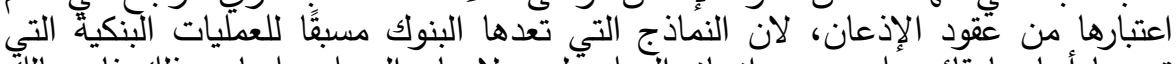

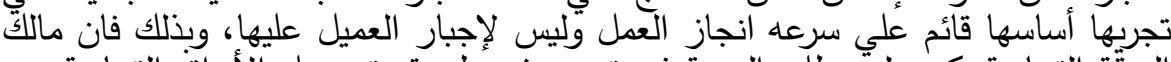

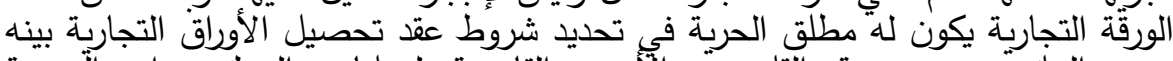

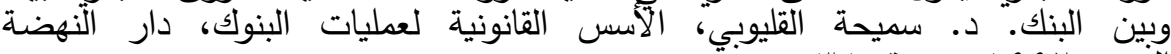

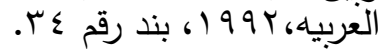

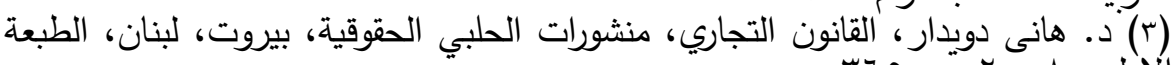

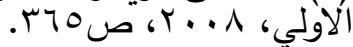
(§) ذا. عبد المجيد بحمح عبودة، النظام البنكى في المملكة العربية السعودية، معهد الإدارة العامة بالمملكة العربية السعودية،

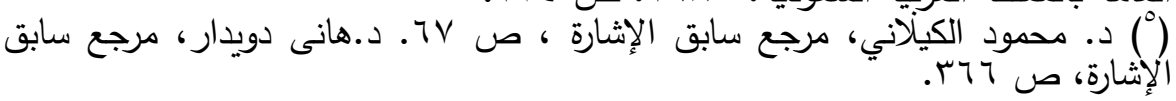


والذي يقوم بموجبه البنك بعمليه تحصيل الأوراق التجارية بالنيابة عن

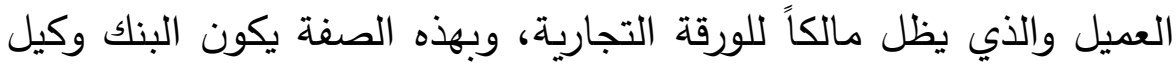

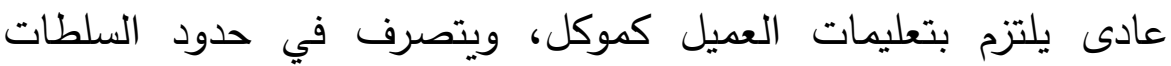

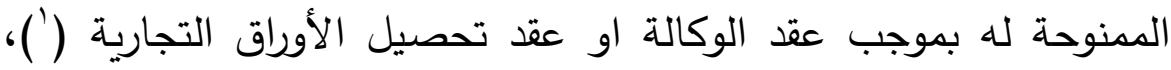

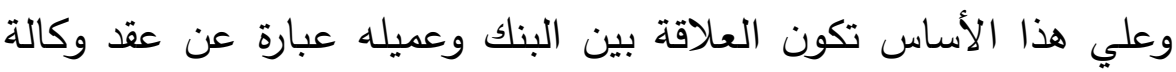

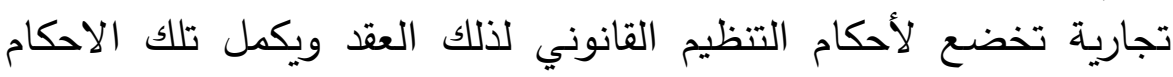
العرف المصرفي (Y)،وقد ذهبت محكمة النقض المصرية الي ذات التهات

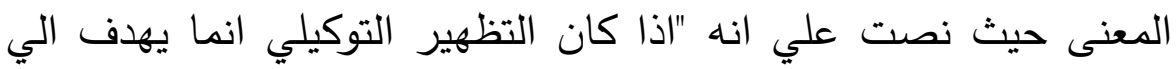

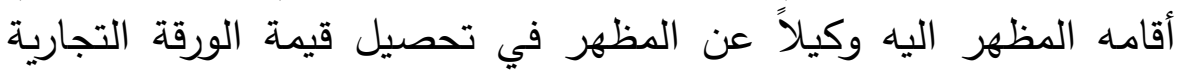
فان العلاقة بينهم تخضع لأحكام الوكالة ..." ( (").

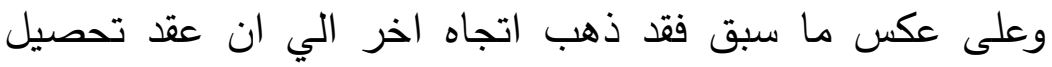

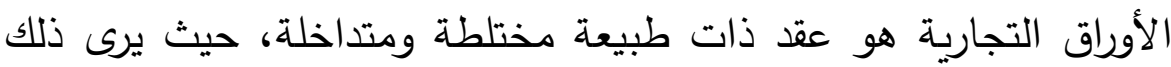

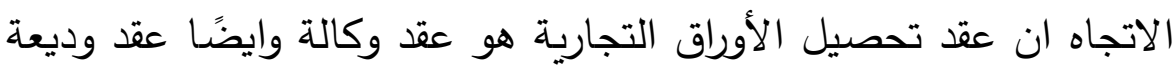

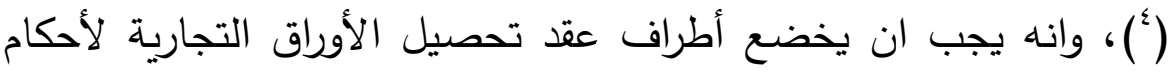
كلا العقدين، ومن ثم فان البنك عند قيامه بتنفيذ عقد تحصيل الأوراق

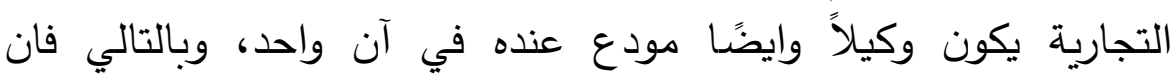

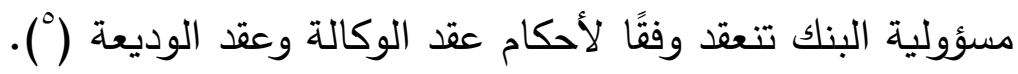

(') ويلاحظ ان عقد تحصيل الأوراق التجارية باعتباره اقرب في تكيفه الى عقد الوكالة

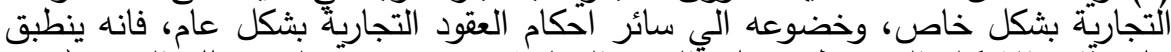

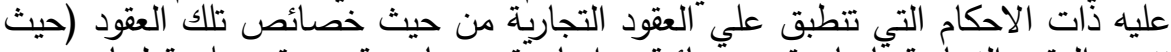

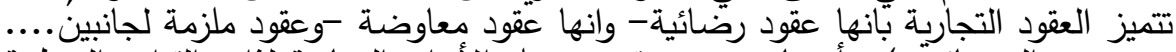

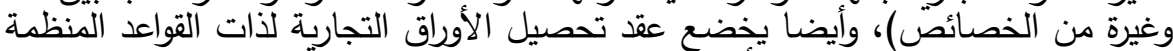

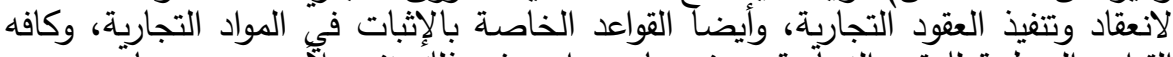

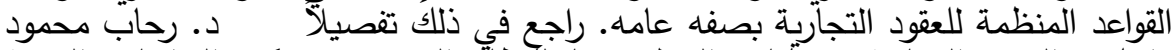

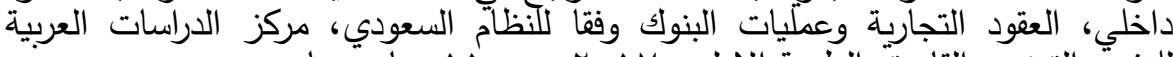

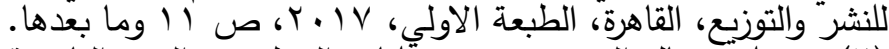

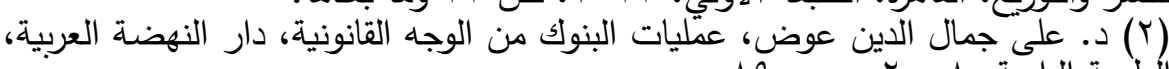

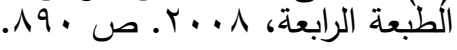

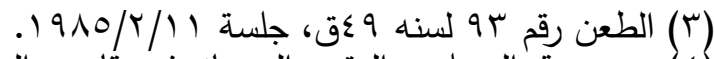

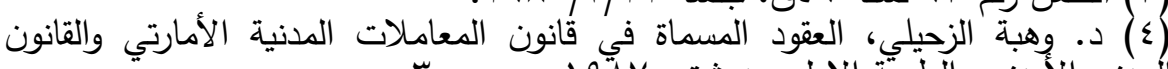

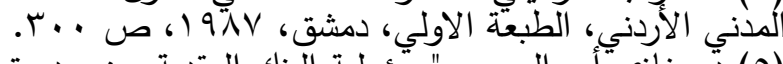

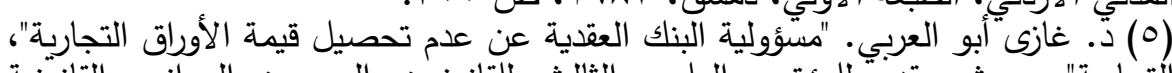

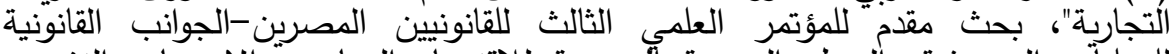

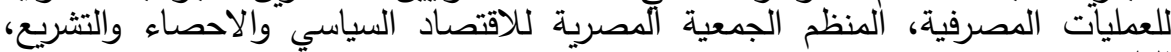

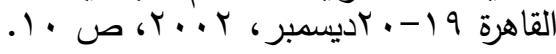


وقد استند ذلك الاتجاه في رأيه الي ان هناك تثابه كبير بين دور البنك كوكيل وبين دور المودع، كذلك فان ذلك الرأي قد وجد في اعتبار عقد تحصيل الأوراق التجارية عقد وكالة ووديعه معًا، هو تحقيق لوديق

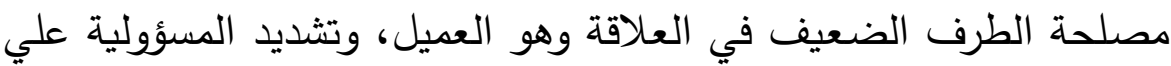

$$
\text { البنك باعتباره الطرف الأقوى في العلاقة ('). }
$$

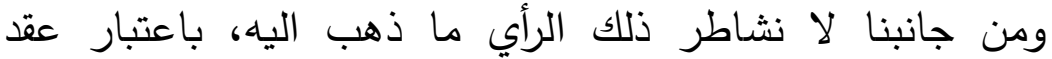
تحصيل الأوراق التجارية عقد وكالة تجارية وليس عقد وديعة، وذلك لأنه

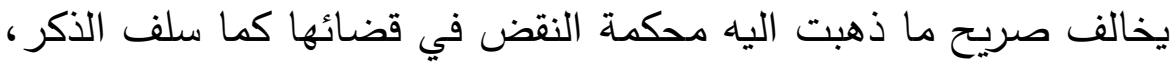
كذلك فبالرغم من ان هناك تثابه كبير بين احكام كلا العقدين، الا انه يوجد اختلاف بينهم ينعكس علي طبيعة مسؤولية البنك وصفته كوكيل في

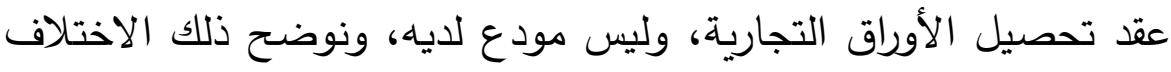
فما يلي: معن: تحن

- من حيث الهُف من كلا العقدين، حيث ان هدف عقد تحصيل

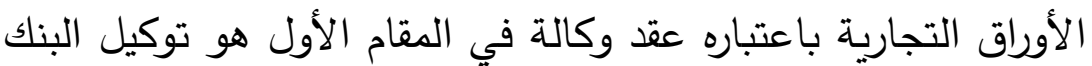

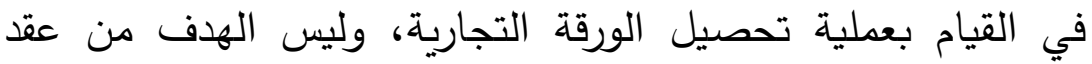

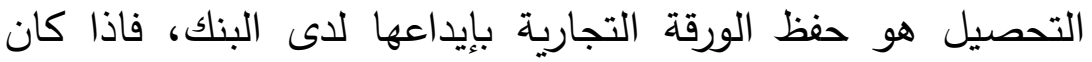

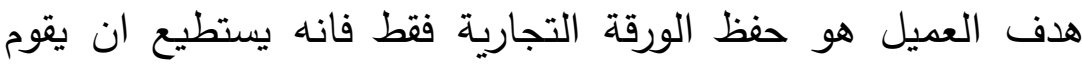

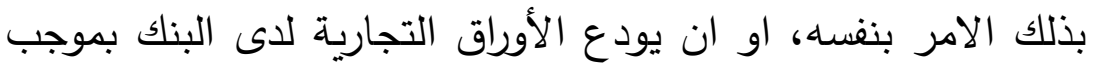

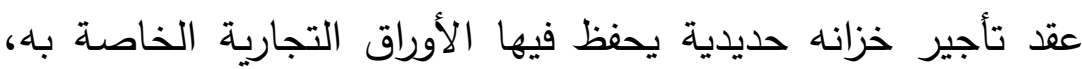

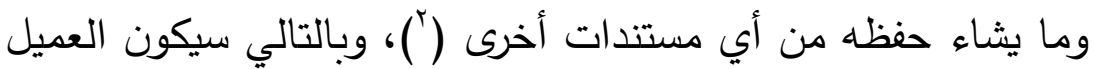

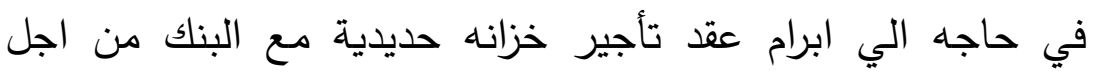

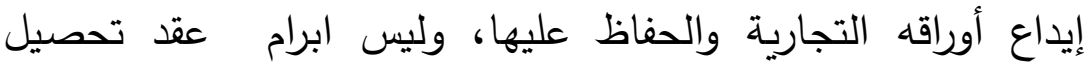

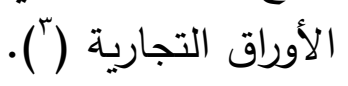

- من حيث محل كلا العقدين، حيث ان محل عقد الوديعة هو حفظ

$\left.{ }^{1}\right)$ (Hamel, Joseph, Op .cit. p.190.

$\left.{ }^{2}\right)$ Hamel, Joseph, Op.cit . p.201.

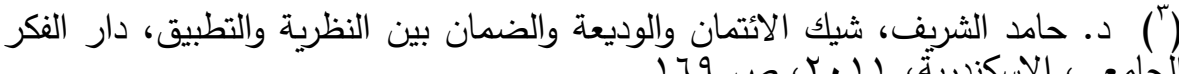

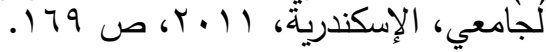


شيء لمصلحة المودع (')، وبالتالي يعتبر محل عقد الوديعة في

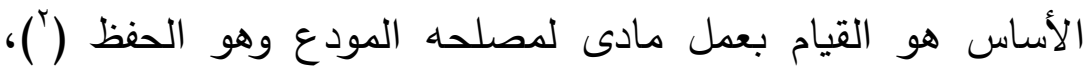
بعكس عقد تحصيل الأوراق التجارية باعتباره عقد وكالة تجارية،

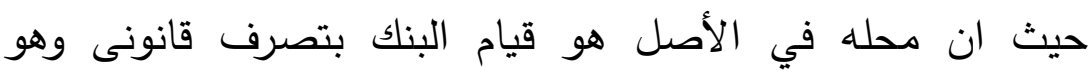
تحصيل قيمة الورقة التجارية لمصلحه عميله، وذلك لا ليمنع من قيام البنك ببعض الاعمال المادية التي تستلزمها عملية تحصيل الورقة

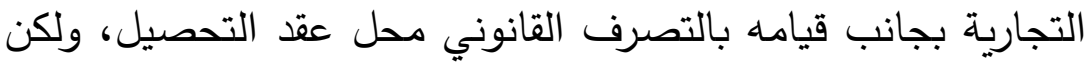

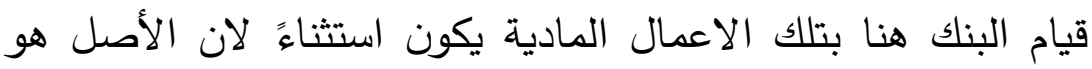

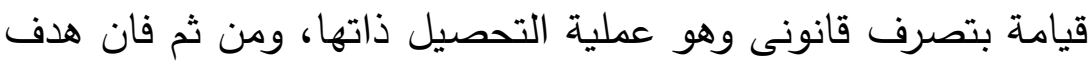
ومحل عقد تحصيل الأوراق التجارية هو تحصية التهيل قيمة الورقة التجارية، علي عكس هدف ومحل عقد الوديعة وهو الحفظ.

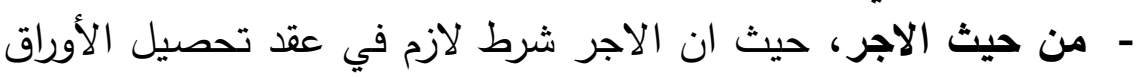

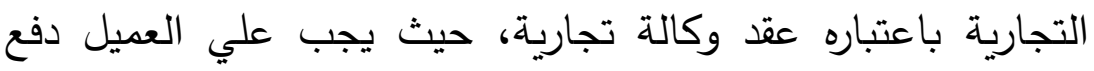
اجر الي البنك عن تحصيل قيمة الورقة التجارية، وذلك بعكس عقد باعداه

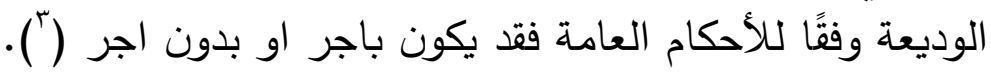

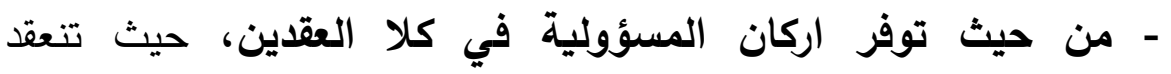

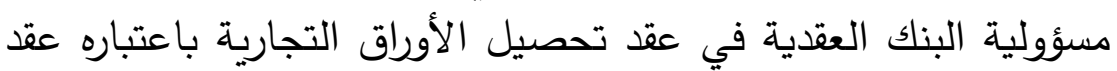

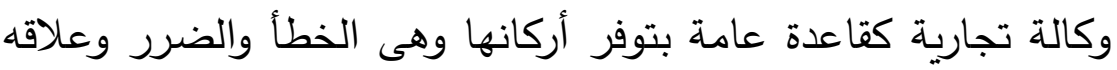

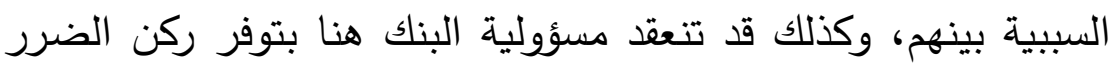
فقط حتى اذا لم يخطأ البنك، اذ يكفي وقوع الضرر علي الني العديل لقيام

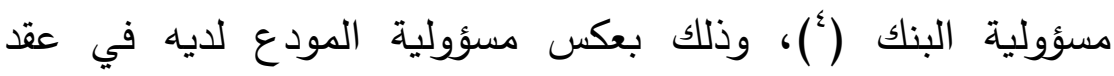

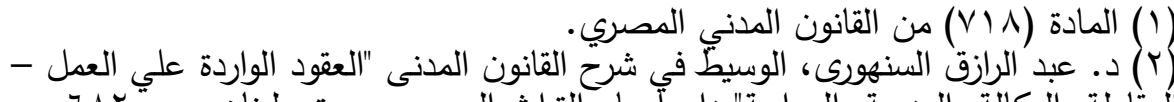

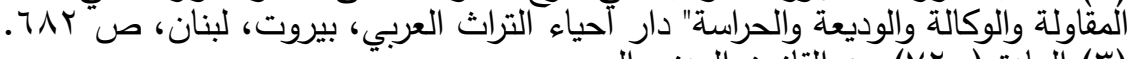

4) (Fredericq, Louis, Dauge, Eugène, Principes de droit commercial belge [Texte imprimé]. tome premier. Actes de commerce, commerçants vente,opérations de bourse gage et warrant, agents commerciaux : commissionnaires, courtiers, agents de change, représentants de commercepréposés, effets de commerce opérations de banque, chèques et comptes-courants,Paris,1991. P.222. 
الوديعة والتي تتطلب لانعقادها توافر اركان المسؤولية العقدية كامله

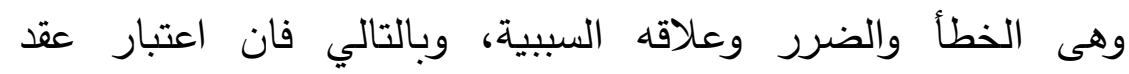

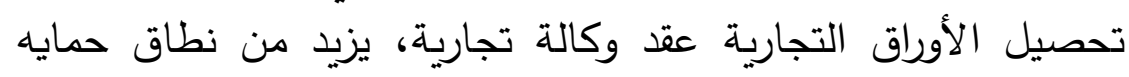
العميل ويسهل عليه رفع دعوى المسؤولية علي البنك. - كذلك من حيث طبيعة الالتزام، حيث ان اعتبار عقد تحصيل الأوراق العيل

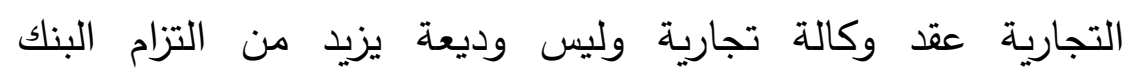

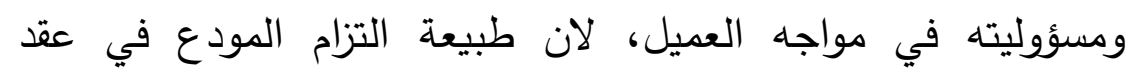

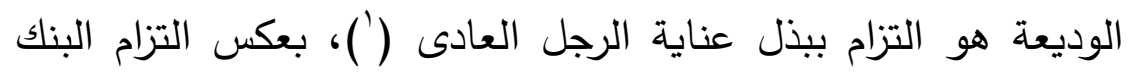

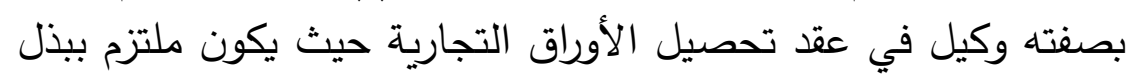

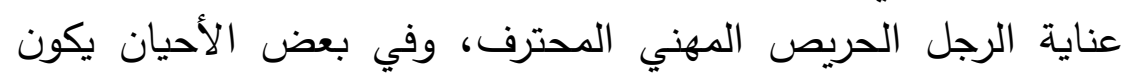
ملتزم بتحقيق نتيجة كما سنرى لاحقًا.

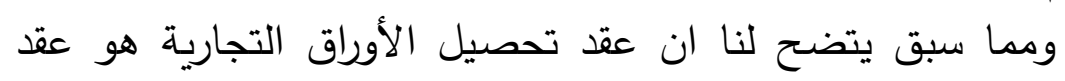

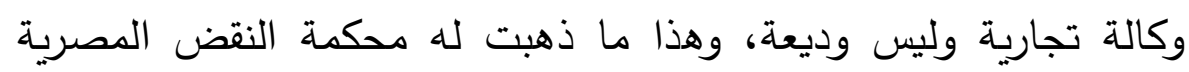

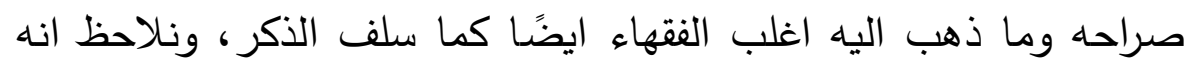
قد يقترن ويختلط عقد تحصيل الأوراق التجارية بعقد الوديعة وذلك في التياء

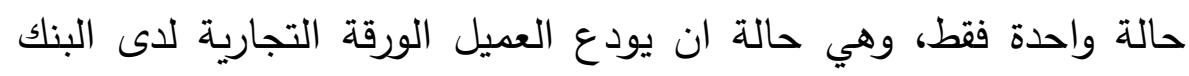
لحفظها في الأساس، ثم يوكل البنك بعد ذلك في القيام بتحصيل قيمتها، فهنا تنعقد مسؤوليه البنك إذا خالف احكام عقد الوكالة التجارية واحكام

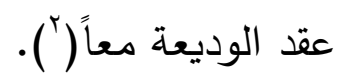

ثانيًا: العلاقات التي تنثأ عن عقد تحصيل الأوراق التجارية.

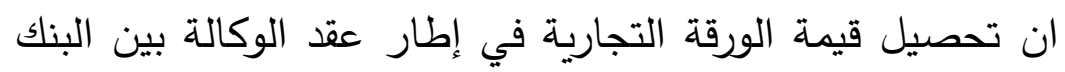

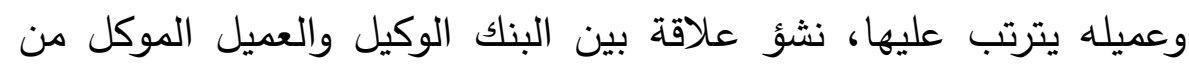
ناحية، ومن ناحية اخري ايضًا تنشأ علاقة بين البنك الوكيل ومدين الوكين الوكيل

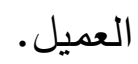

فبالنسبة للعلاقة الاولي بين البنك الوكيل والعميل الموكل (")،

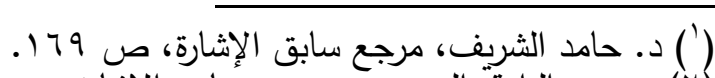

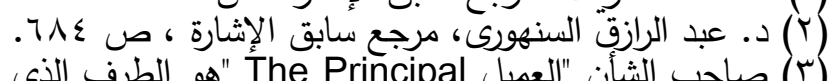

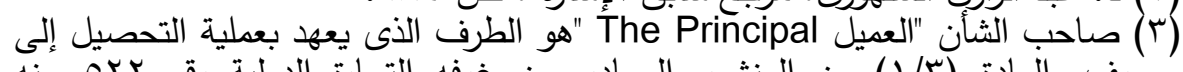

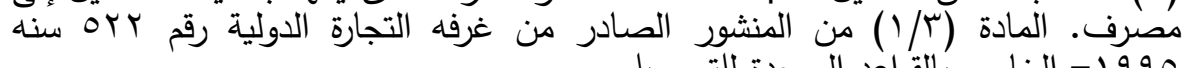


فكما سبق القول فهي علاقة يحكمها وينظمها احكام عقد الوكالة، وتنشأ العلاقة بين البنك والعميل بمجرد ابرام عقد تحصيل الأوراق التجارية، وتنتهى بمجرد قيام البنك بعمليه التحصيل وايداع المبلغ في حساب البراب العميل، وبالطبع فان البنك ملتزم بتنفيذ التزاماته الناشئة عن عقد تحصيل

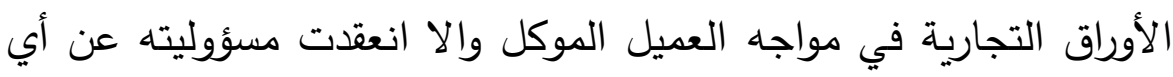

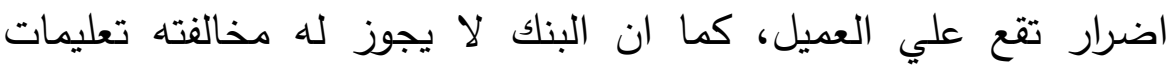
العميل او الخروج عنها اثناء تنفيذ عقد تحصيل الأوراق التجارية.

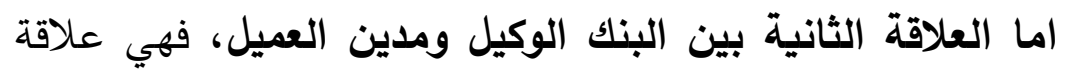
بين وكيل ومدين موكله، يحكم حدودها عقد الوكالة - او عقد تحصيل

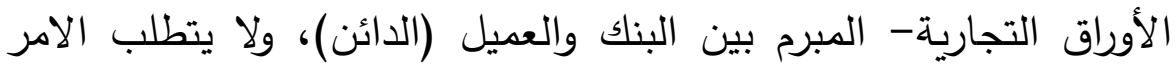

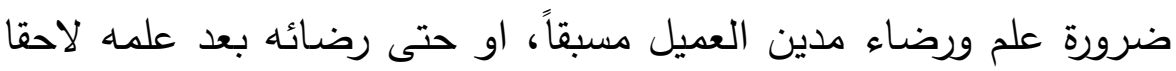

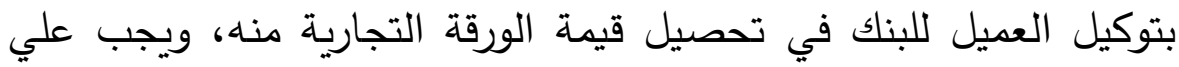

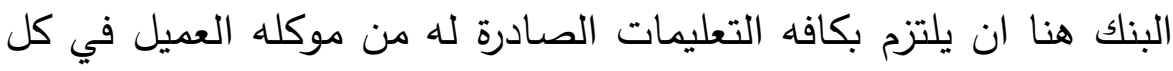

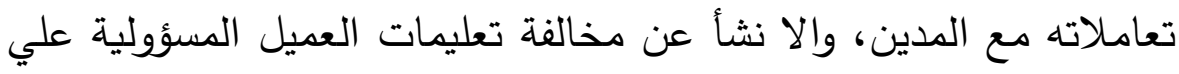
عاتق البنك (')، حيث يلتزم البنك بتعليمات موكله فيما يتعلق بطريقه واتله

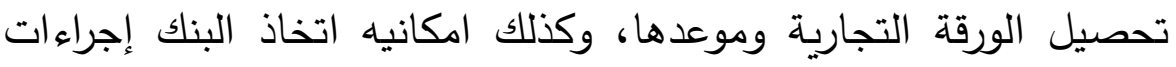

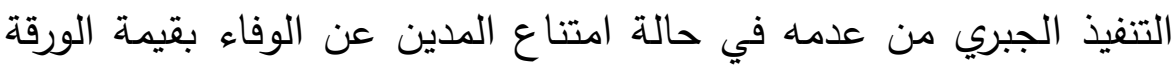

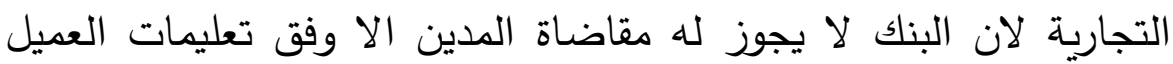

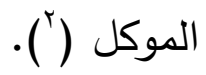

ومن ثم فان العلاقة بين البنك ومدين العميل ليست علاقة عقديه،

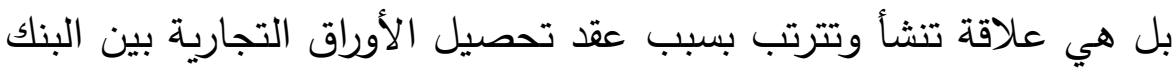
والعميل، وتنحصر هذه العلاقة في كون البنك وكيل في تحصيل قيمة الورقة التجارية من مدين العميل، فاذا قام البنك بتحصيل قيمه التها الورقية

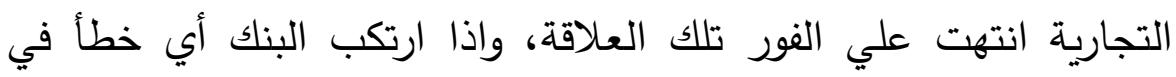
حق مدين العميل عند تحصيل الورقة التجاريـة، فان البنك يسأل مسؤوليه

(1) Mallarmé, Victor, Des Opérations de banque relatives aux effets de commerce, Université de Paris. Faculté de droit et des sciences économiques, 1987. P. 214.

$$
\text { د. دممود الكيلاني، مرجع سابق الإشارة ، ص } 79 \text {. } 79 .
$$


تقصيريـه في مواجه ذلك المدين ('). وترتيبًا علي ما سبق فان تكييف العلاقة وتحديد طبيعتها بين

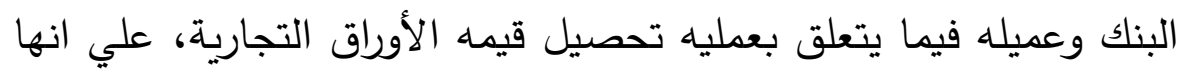

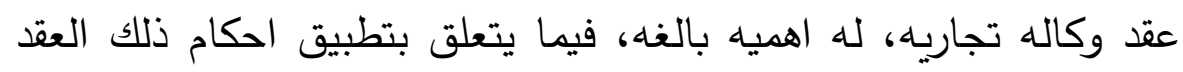

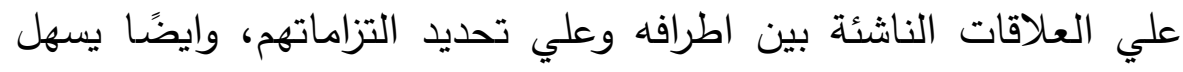
تحديد طبيعة ونوع المسؤولية الناشئة عن الاخلال بتنفيذ العقد فيما بين

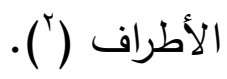

\section{نوع التظهير في عقد تحصيل الأوراق التجارية.}

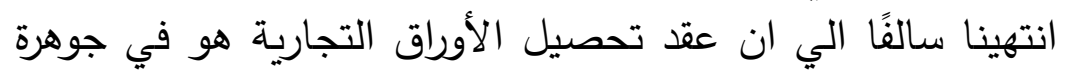
عقد وكالة، وان العميل عليه توكيل البنك في تحصيل قيمه الورة الورقة التجارية، ومن ثم يجب علي العميل ان يظهر الورقة التجارية تظهير

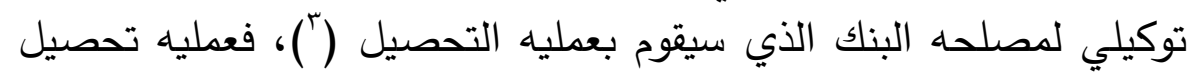

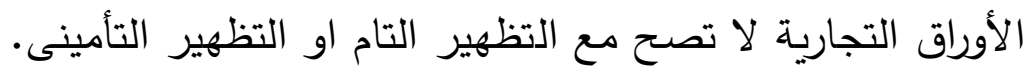

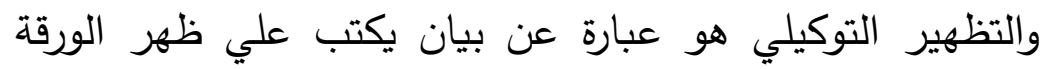
التجارية من المظهر بقصد توكيل من ظهرت إليه الورقة التجارية ليكون

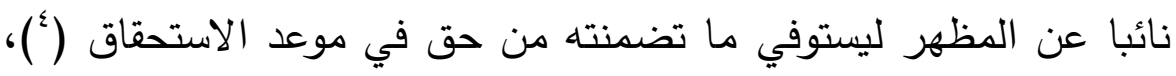

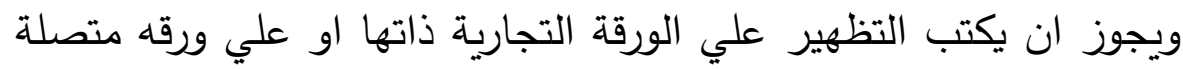

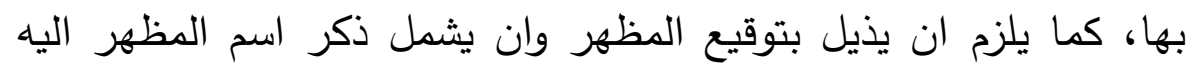

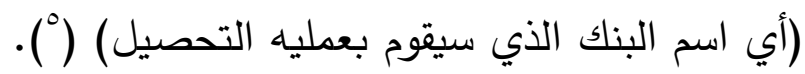

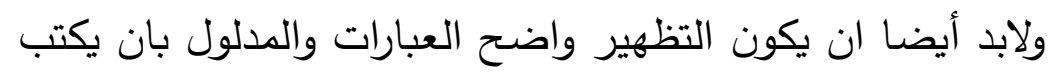
العميل القيمة للتحصيل او القيمة للقبض او أي عبارة اخري تفيد بشكل

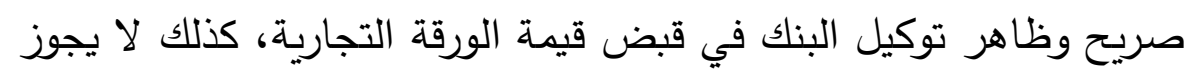

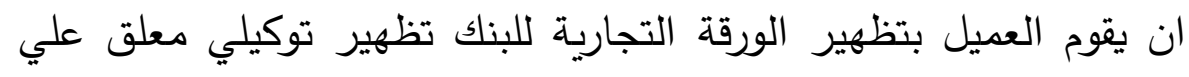

(r) د. كامل الوادي، الاعمال المصرفية والقوانين المنظمة لها (الجزء الأول) ، الأمارات

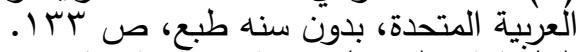

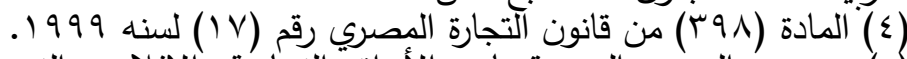

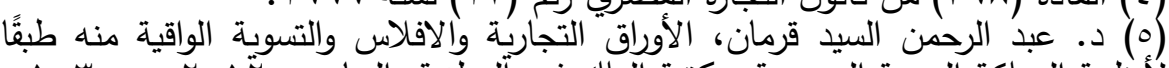

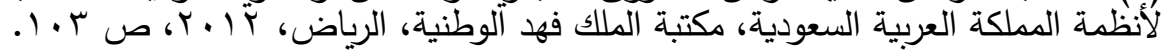


شرط حيث يبطل الشرط ويكون التظهير صحيح (')، كذلك لا يجوز ان

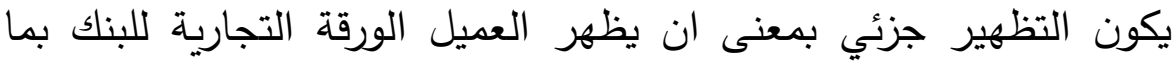

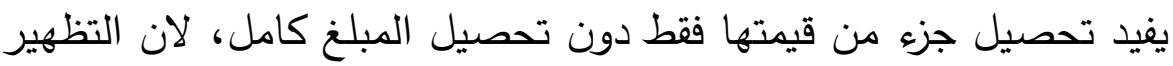

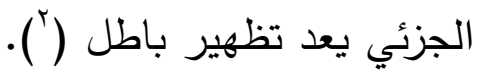

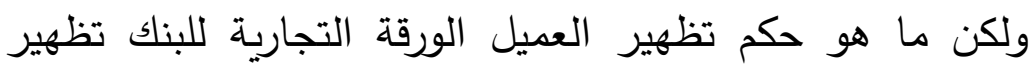

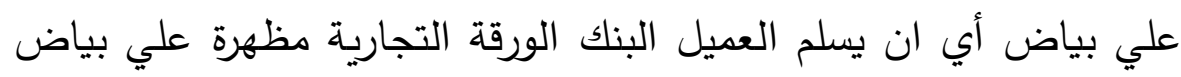

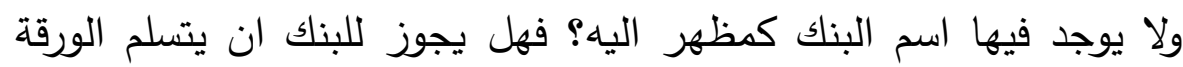

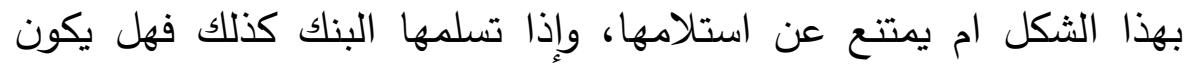

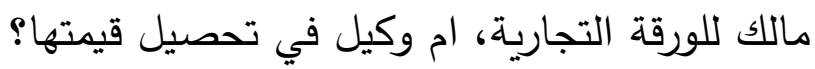
بالطبع يحق للبنك في الأساس ان يرفض تسلم التصلي الورقة التجارية التي لا يتضح فيها قصد العميل القطعي علي تفويض البنك في تحصيل قيمتها وذلك من خلال العبارات التي تدل علي التظهير التوكيلي بشكل

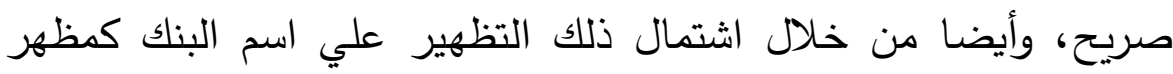

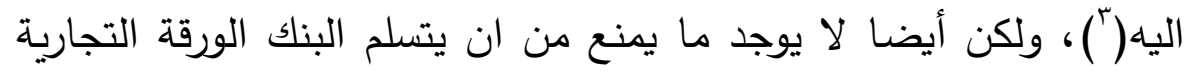

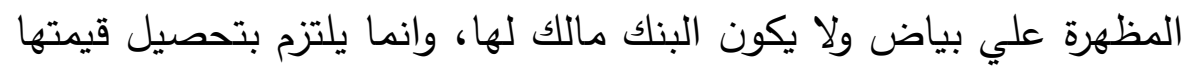

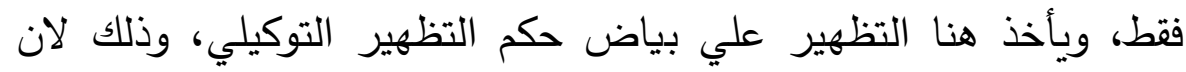

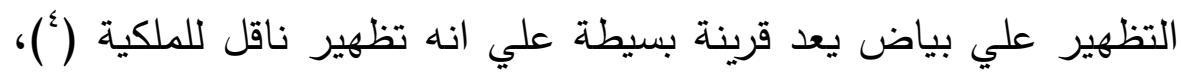

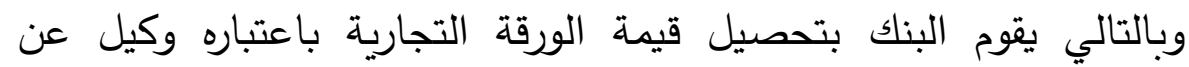

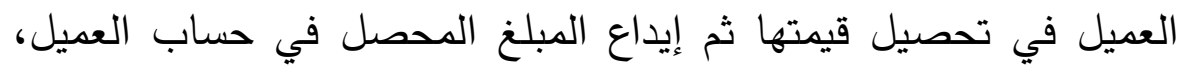
ولا يقوم البنك بالتحصيل بصفته مالك الورقة التجارية، وهذا ما ذهبت اليه محكمة النقض المصريسة في قضائها (1). وايضًا قد يأتي التظهير بشكل معيب، بان تكون عباراته مثلا غير

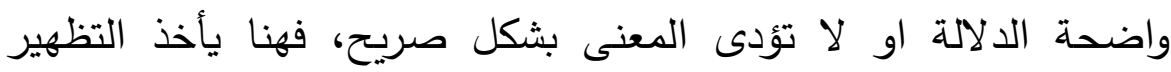
المعيب ذات الحكم الخاص بالتظهير علي بياض بالنسبة لاعتبار البنك

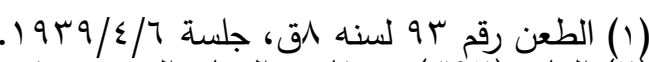

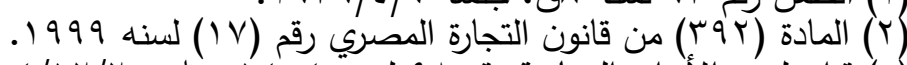

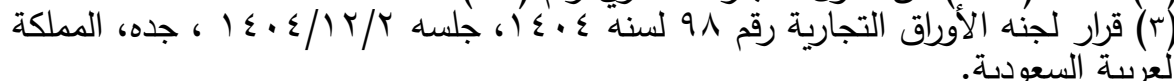

Mallarmé, Victor. Op Cit .P. 210.

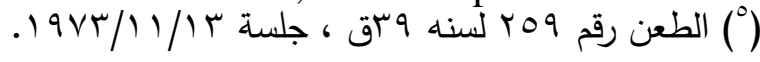


وكيل في تحصيل قيمة الورقة التجارية المظهرة تظهير معيب (').

\section{المبحث الثاني \\ طبيعة مسوفلية البناك في عقد تصميل الأوراق التجارية واركانها}

\section{تمهيل وتقسيم.}

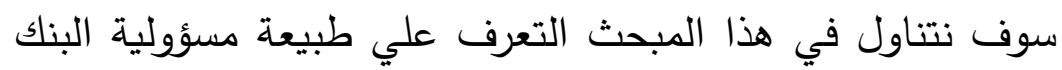

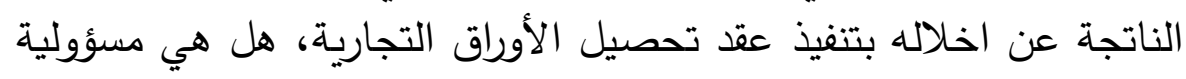
عقديه فقط ام يجوز ان تكون مسؤولية تقصيرية في بعض الأحئ لأحيان،

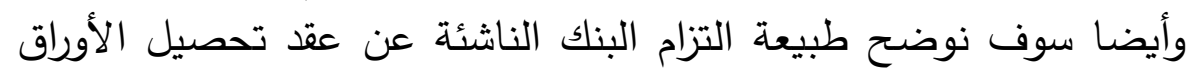
التجارية (المطلب الاول)، ثم نستكمل الحديث عن اركان مسؤولية البنك الكي

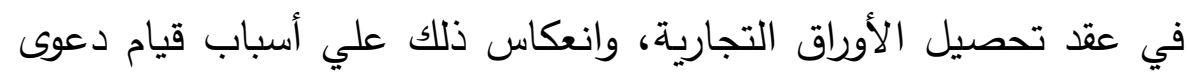
المسؤولية علي البنك (المطلب الثاني).

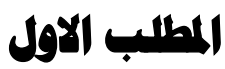

\section{طبيعة مسؤولية البنك في عقد تهميل الأوداق التجارية وطبيعة التتزامهن}

نحاول في ذلك المطلب التعرف علي طبيعة مسؤولية البنك في

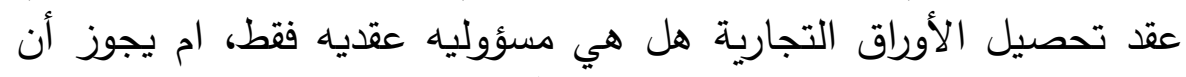

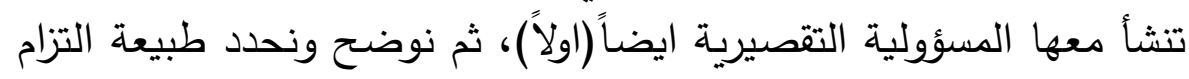

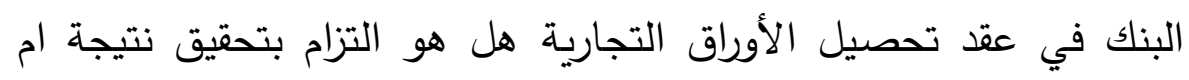
التزام ببذل عنايه (ثانيًا).

اولاً: طبيعة مسؤولية البنك في عقد تحصيل الأوراق التجارية:

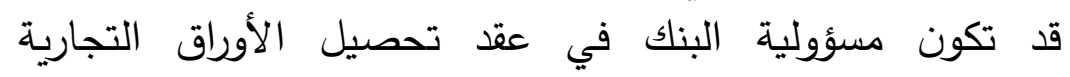

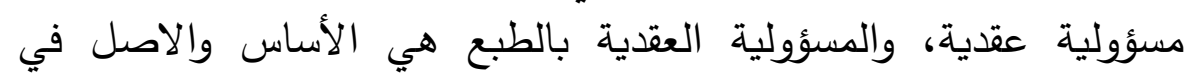

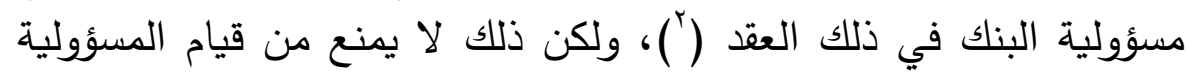

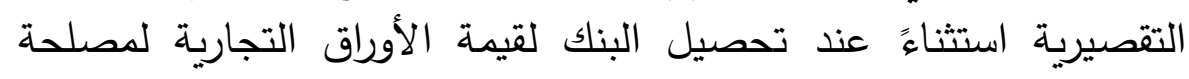
عميله، وسوف نتحدث فيما يلي عن ذلك تفصيلاً. • المسؤولية العقدية للبنك.

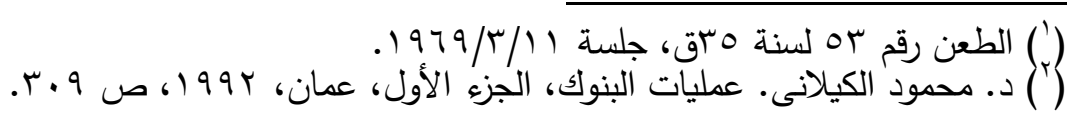
مسؤولية البنك الناثئة عن عقد تحصيل الأوراق التجارية 
كما سلف الذكر فقد انتهينا الي ان العلاقة بين البنك والعميل فيما

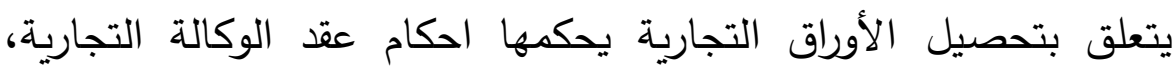
وبالتالي فان أي اخلال بتنفيذ الالتزامات التي تنشأ عن عقد تحصيل الأليل

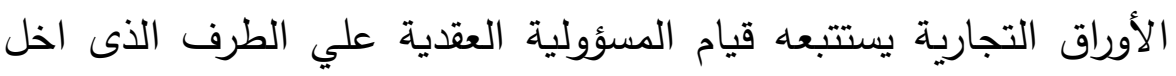
بتنفيذ التزامه، ومن ثم فان اخلال البنك بتنفيذ التزامه في مواجه العميل

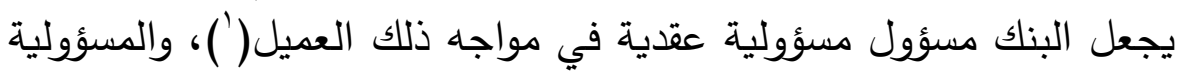

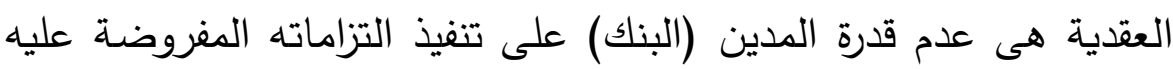

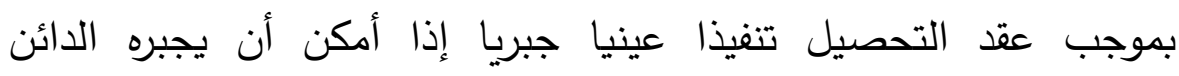

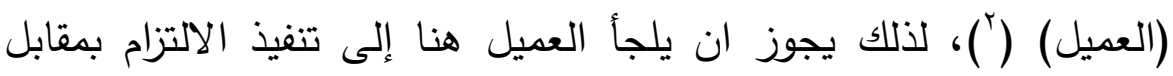

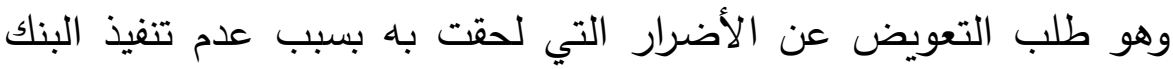

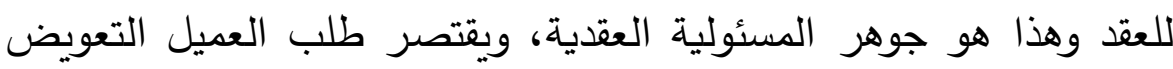

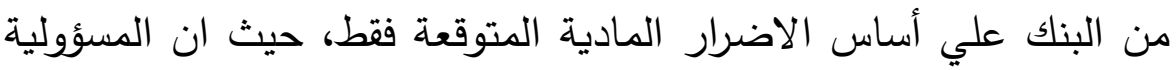

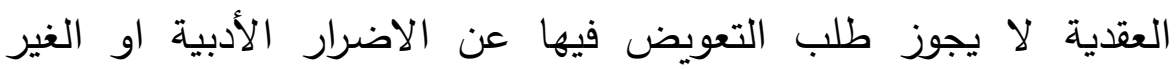
متوقعه (r). ولكي تقوم المسؤولية العقدية في حق البنك، فلابد ان يكون هناك

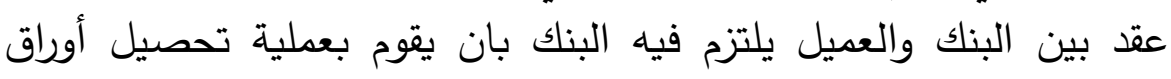
تجاريـة لمصلحة العميل، ولذلك فلابد ان يكون ذلك العقد قد نشأ صحيحًا من الناحية الشكلية والموضوعية، وان يكون عقد مكتمل الأركان حيث يجب ان يتوفر في عقد تحصيل الأوراق التجارية ركن الرضا والأهلية

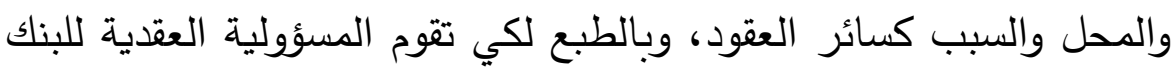

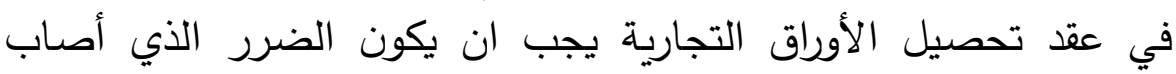
العديل قد وقع ونتج عن تنفيذ البنك لذلك العقد (أ).

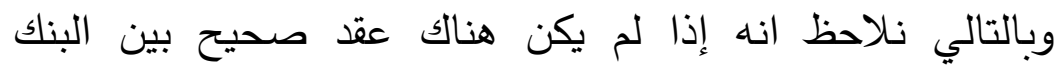
والعميل، وإذا لم يرتكب البنك خطأ عقدي يترتب عليه ضرر للعميل عند

1) p.268.

(Hamel, Joseph, Op.cit.

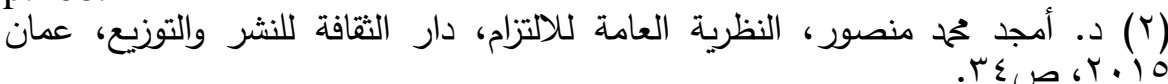

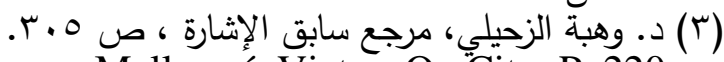
Mallarmé, Victor. Op Cit . P. 220. 
قيامه بتحصيل الورقة التجارية، فلا مجال هنا للحديث عن المسؤولية

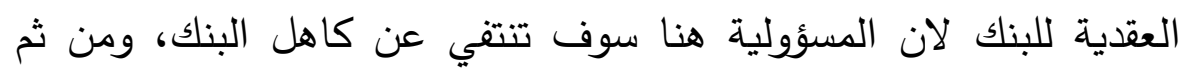
فان الاخلال بالالتزام العقدى للبنك في عقد تحصيل الأوراق التجارية يقوده الي قيام المسؤولية العقدية عليه.

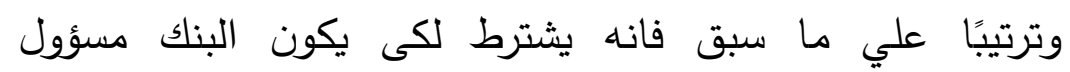
مسؤولية عقدية في مواجه العميل عند تحصيل الأوراق التجارية: - أن يكون عقد تحصيل الأوراق التجاريـة المبرم بين البنك والعميل عقدًا

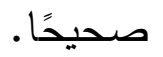
- أن يكون هنالك عقد بين البنك والعميل يلتزم فيه الأول بان يقوم

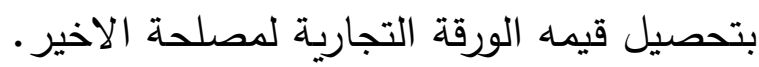

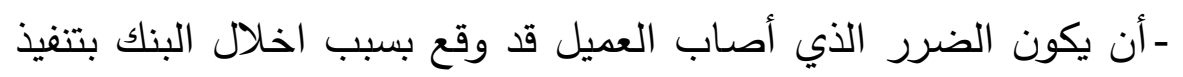
عقد تحصيل الأوراق التجارية. المسؤولية التقصيريـة للبنك.

اذا كان الاخلال بالالتزامات العقدية الناشئة عن عقد تحصيل الأوراق التجارية يؤدى الي قيام المسؤولية العقدية علي البنك وفقًا للأحكام

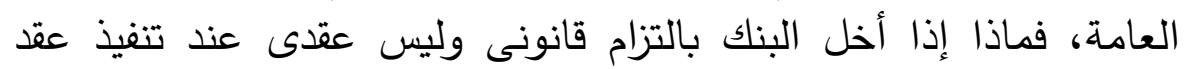
تحصيل الأوراق التجارية، بالطبع فان البنك سيكون مسؤول مسؤولية

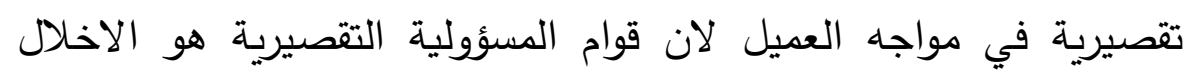

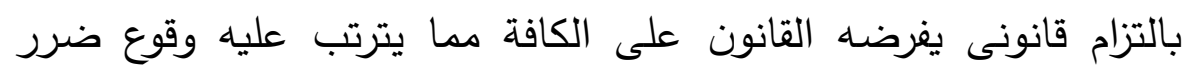
علي العميل (1)، ويلتزم هنا البنك بتعويض العميل عن الاضرار الأدبية

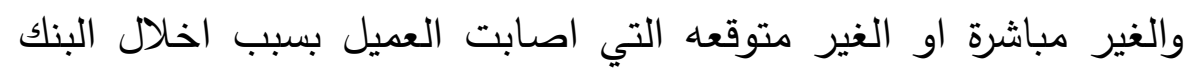

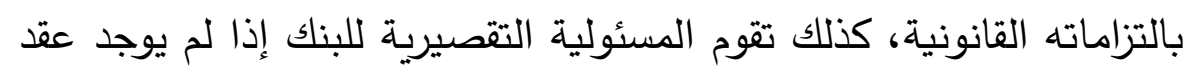

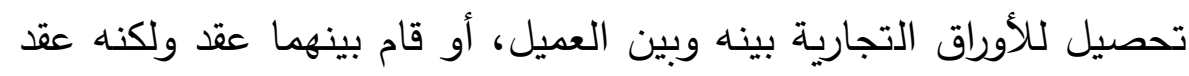
باطل أو تقرر بطلانه، وهنا تنعقد مسؤولية البنك التقصيريـة.

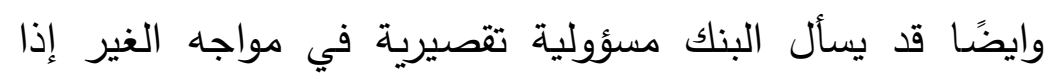
أحدث له البنك ضرر بسبب تنفيذه عقد تحصيل الأوراق التجارية، اذ ليس فيس لئه

(1) د. دأ محمود جمال الدين زكى، مشكلات المسؤولية المدنية الجزء الأول، مطبعه جامعة

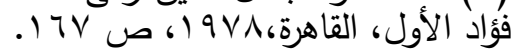


بين الغير والبنك علاقة عقدية لذلك تتعقد مسؤولية البنك التقصيرية في

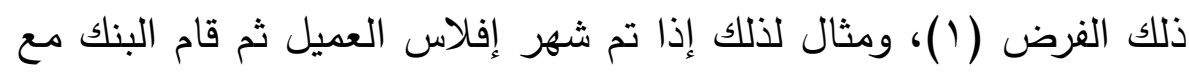

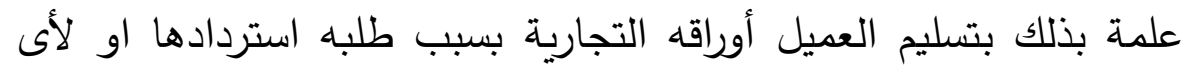

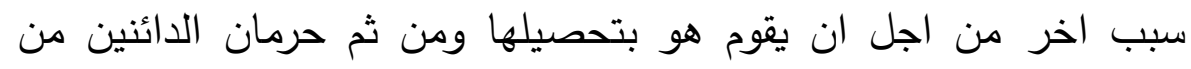

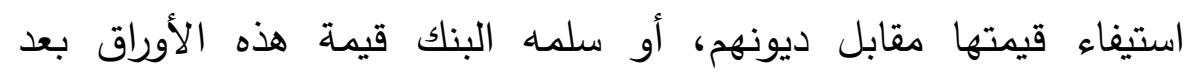

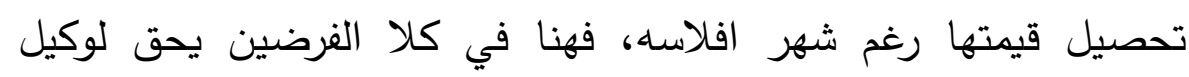

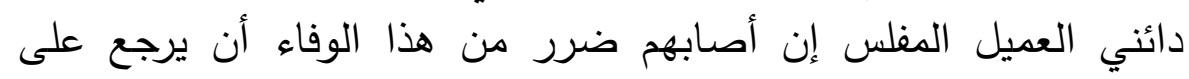
البنك بالتعويض تأسيسا على احكام المسؤولية التقصيرية.

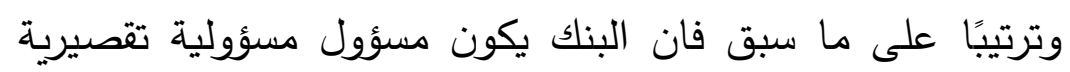

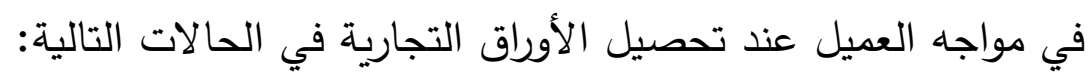
- - حالة عدم وجود عقد لتحصيل الأوراق التجارية بين البنك والعميل.

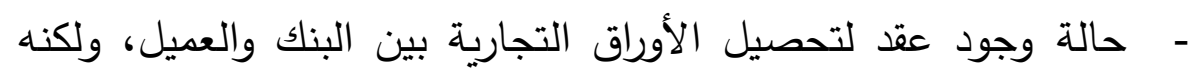
عقد باطل او حكم ببطلانه.

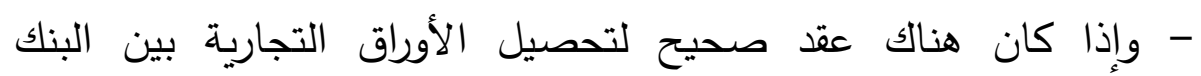

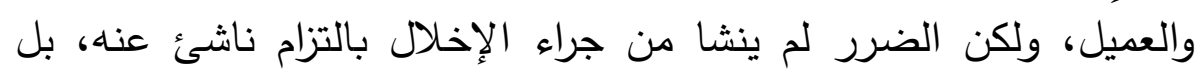
نشأ بسبب اخلال البنك بالتزام قانوني (r).

ثانيًا: طبيعة التزام البنك في عقد تحصيل الأوراق التجارية:

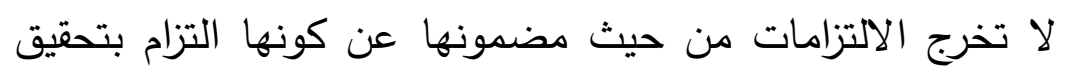

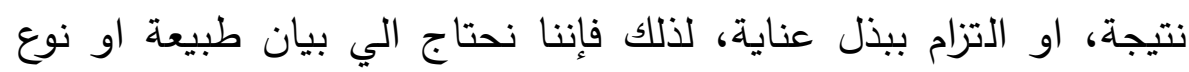

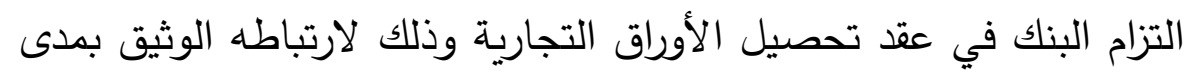
قيام مسؤولية البنك او جواز اعفائه منها.

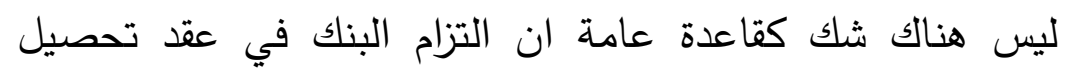

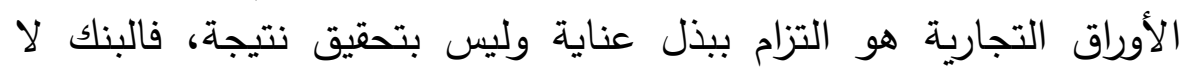
يلتزم بتحقيق نتيجة وهي ضرورة تحصيل الورقة التجارية، ولا يجوز انعقاد

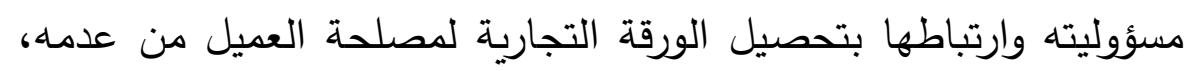
اذ ان مناط التزام البنك هو بذل العناية المطلوبة من جانبه في سبيل لوديل

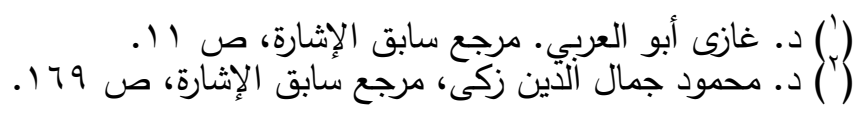
مسؤولية البنك الناثئة عن عقد تحصيل الأوراق التجارية 
تحصيل قيمة الورقة التجارية فقط، فاذا أخل البنك بذلك الالتزام وهو بذل منان العناية المطلوبة فهنا يجوز مسألته من قبل العميل (').

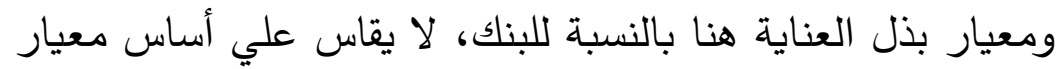

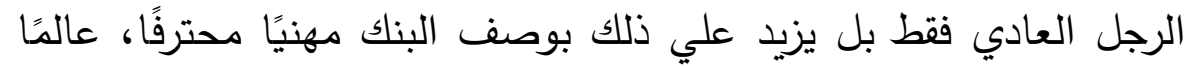

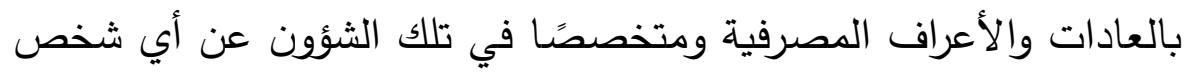

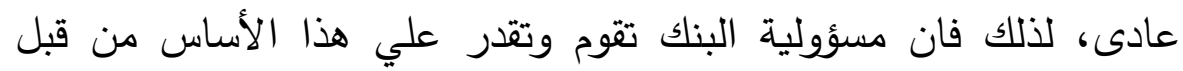

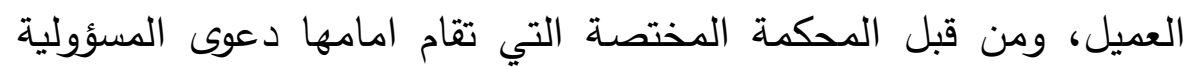

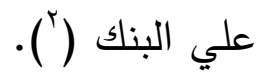
كذلك يجب على البنك ان يتصرف بأمانه وان تكون مصلحة

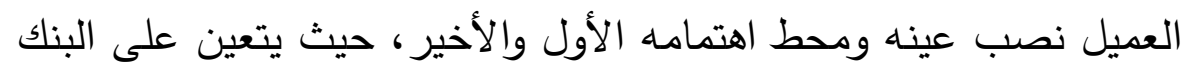
في هذا النوع من الالتزامات ان يبذل قدر من العناية والحرص الثديد

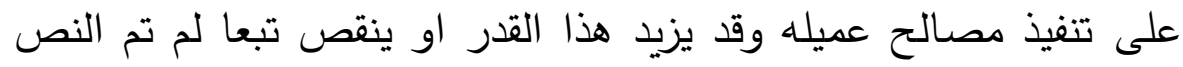

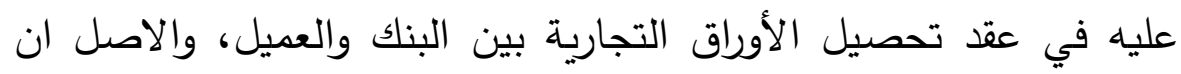

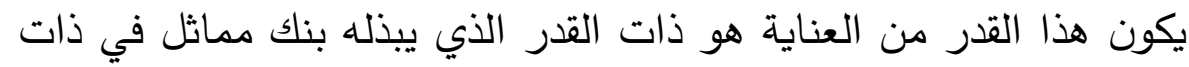
ظروف تنفيذ الالتزام من قبل بنك العميل (").

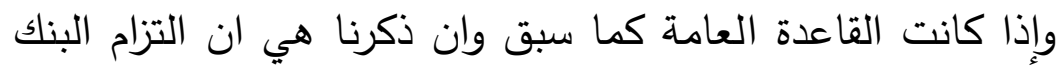
هو التزام ببذل عناية في عقد تحصيل الأوراق التجارية، فان الاستثناء دوناء

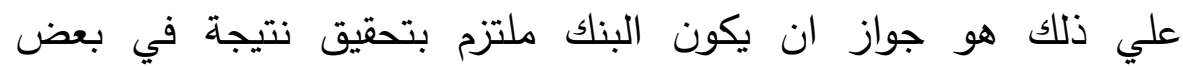
الأحيان، وبالتالي تختلف طبيعة مسؤولية البنك وتختلف أسباب انعقادها، حيث يكون البنك مكلف بتحقيق غاية وهدف محدد لا تنفك مسؤوليته الا

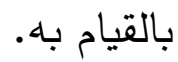

ومن الأمثلة التي يكون فيها التزام البنك التزام بتحقيق نتيجة هو كل ما يجب علي البنك من اتخاذه فيما يتعلق بإجراءات المحافظة علي

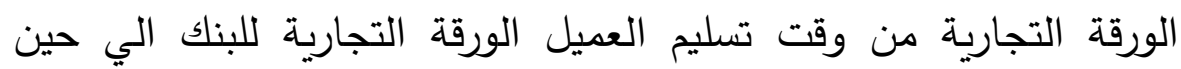
تحصيلها، حيث يجب ان يحافظ البنك علي الورقة محافظه مادية فلا

Mallarmé, Victor. Op Cit. p.266.

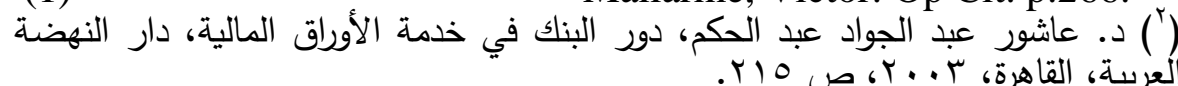

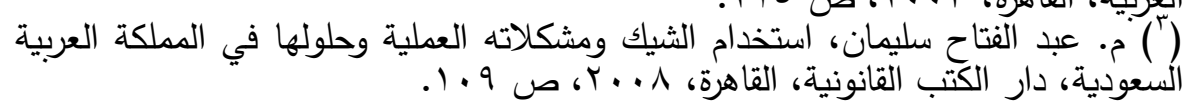


يجوز ان يعرضها للتلف او الحرق او الغرق او الضياع وما الي ذلك

كذلك يجب علي البنك ان يحافظ علي الورقة التجارية من

الناحية القانونية حيث يلتزم البنك ويكون مسؤول امام العميل عن القيام

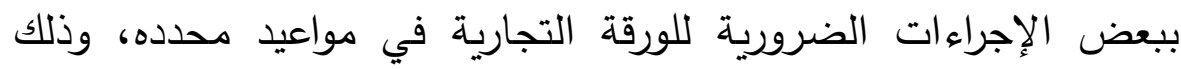
علي سبيل المثال من حيث تقديم الورقة التجارية للمسحوب عليه عليه للحصول علي القبول، وأيضا تحرير برتستو عدم القبول، وتقديم الورقة

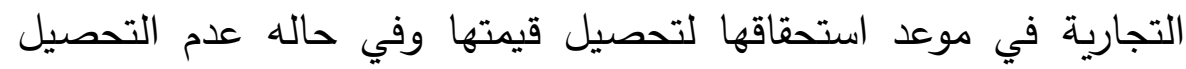
يجب علي البنك تحرير برتستو عدم الدفع، وغيره الكثير من الإجراءات

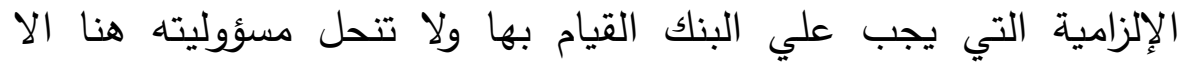

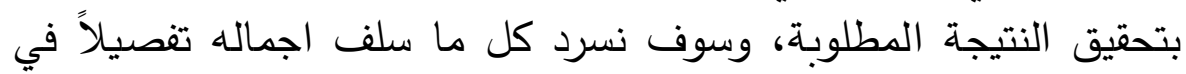
معرض اخر لاحق في سياق هذا البحث. كذلك قد يكون التزام البنك التزام بتحقيق نتيجة استثناء إذا الزاء الزم البنك نفسه في عقد تحصيل الأوراق التجارية بالتزامات محدده تجاه العميل، كما إذا الزام البنك نفسه بانه مسؤول عن تحصيل قيمة الورقة

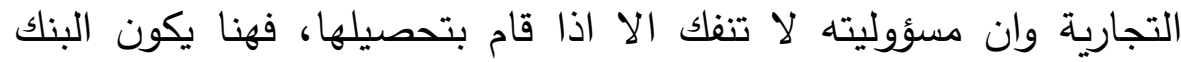

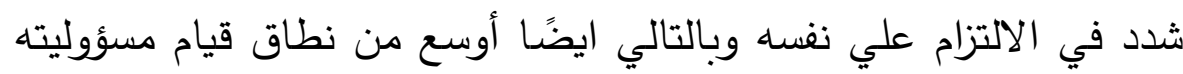
تجاه العميل، ولا يكون مثل ذلك الشرط غير صحيح لان لان العلاقة بين

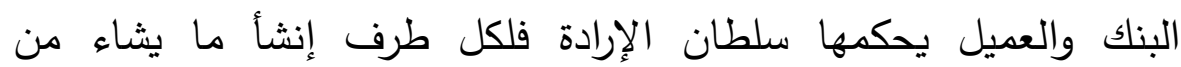

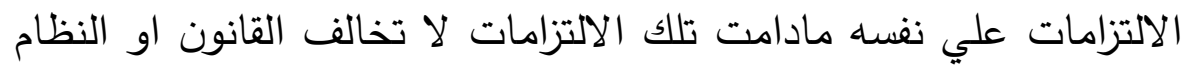

\section{الإطلب الثاني}

\section{اركان هسؤولية البنـك في عقد تصصيل الأوراق التجارية}

انتهينا الي ان مسؤوليه البنك تجاه العميل فيما يتعلق بتنفيذ عقد تحصيل الأوراق التجارية هي مسؤولية عقديه واحيانًا قد تكون مسؤولية

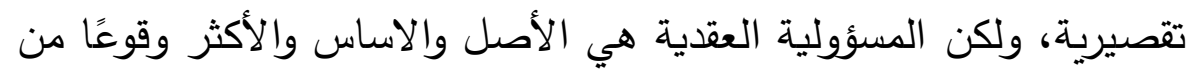

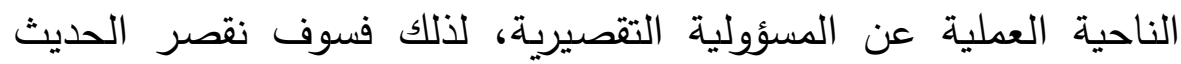

Mallarmé, Victor. Op Cit .p. 269.

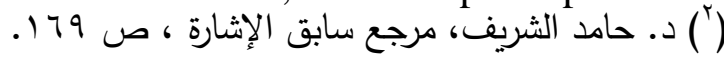


علي ضرورة توفر اركان المسؤولية العقدية حتى يتم رفع دعوى المسؤولية على البنك علي أسس سليمه، وبالطبع فلكي تقوم مسؤولية البنك العقدية

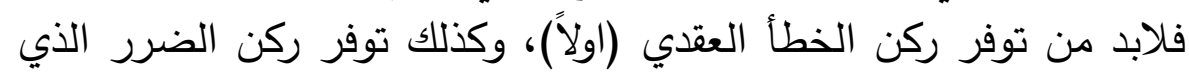

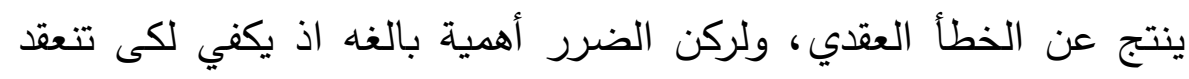

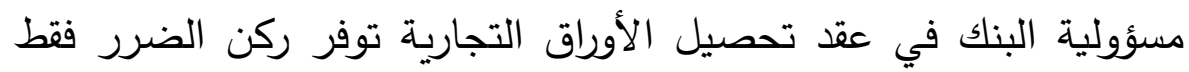

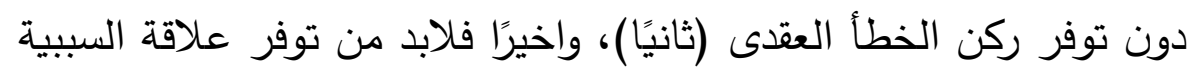
بين خطأ البنك والضرر الواقع علي العميل (ثالثًا). اولاً: ركن الخطأ العقدي للبنك.

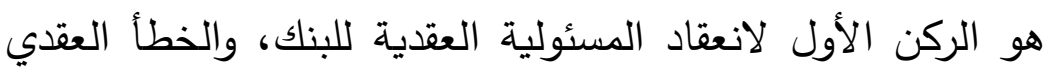

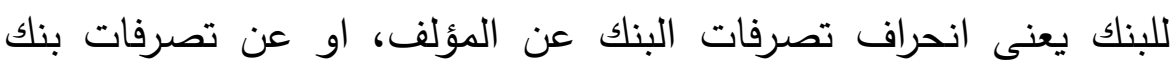
اخر مماثل له في ذات الواقعة.

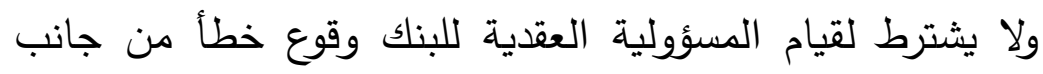
البنك، بل يكفي اخلاله بالتزاماته العقدية النشأة عن عقد تحصيل الأوراق

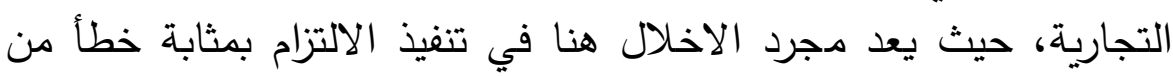

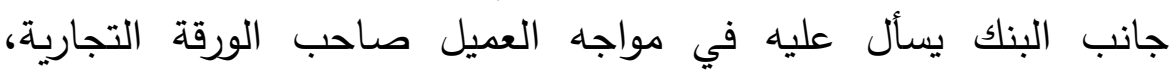
ويتحقق خطأ البنك في عقد تحصيل الأوراق التجارية في الحالات التالية:

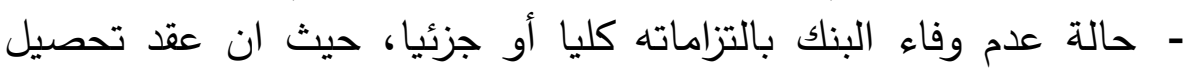

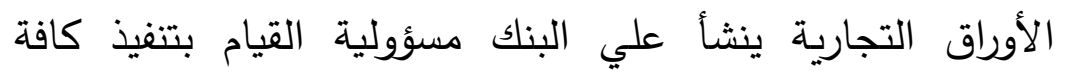

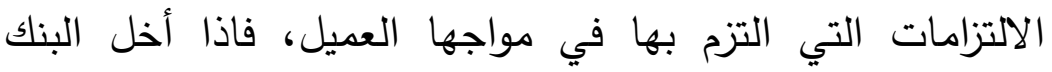

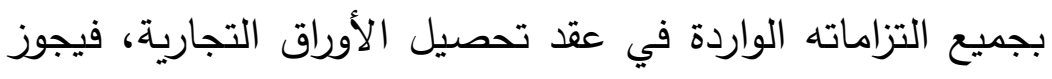

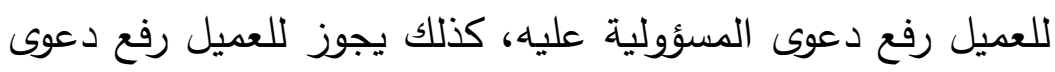

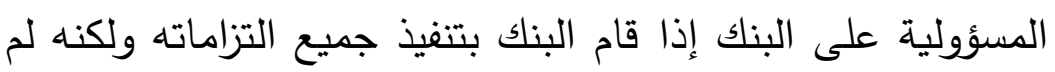

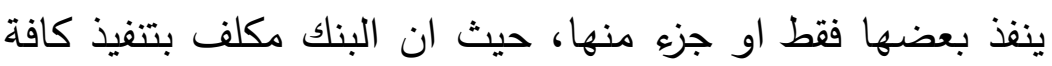

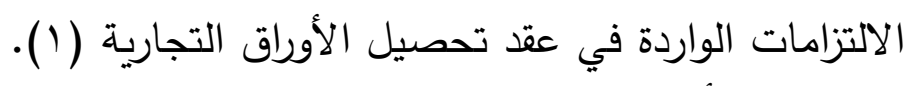

- كذلك يتوفر الخطأ العقدى في جانب البنك إذا قام بتنفيذ كافة التزاماته الواردة بعقد تحصيل الأوراق التجارية ولكنه قام بالتنفيذ على وجها

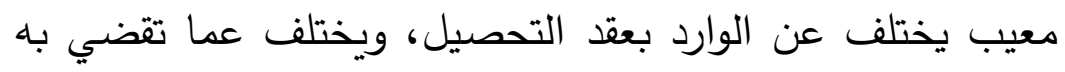

(') د. محمود جمال الدين زكى، مرجع سابق الإشارة، ص IV^. مسؤولية البنك الناثئة عن عقد تحصيل الأوراق التجارية 


$$
\text { الأعراف المصرفية للبنوك بشكل عام ('). }
$$

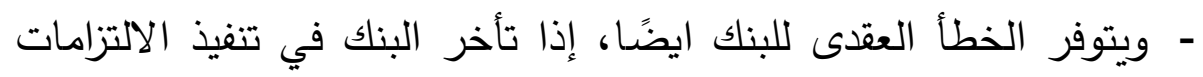

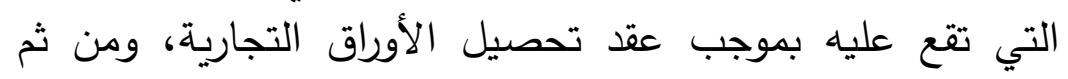

يجوز للعميل رفع دعوى المسؤولية عليه.

ويستوي أن يكون خطأ البنك العقدى قد وقع عن عمد المد اولة الهمال

وتقصير (')، ويتحقق خطأ البنك العقدى إذا وقع من ممثل البنك القانوني

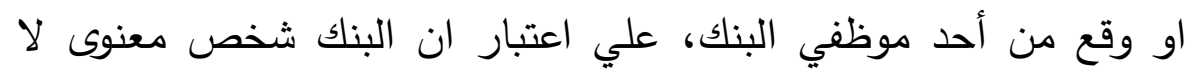
يمكنه القيام بذاته بارتكاب الخطأ،كذلك يسأل البنك عن أي خطأ يرتكبه أبها أي شخص عهد اليه البنك من الباطن في تنفيذ عقد تحصيل الأوراق

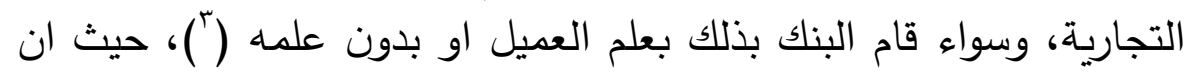

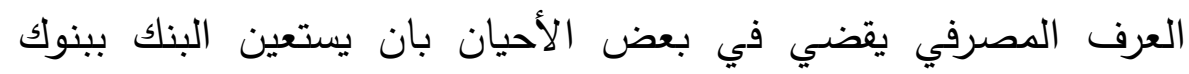

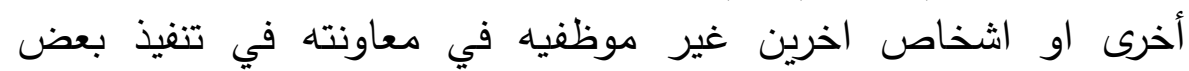

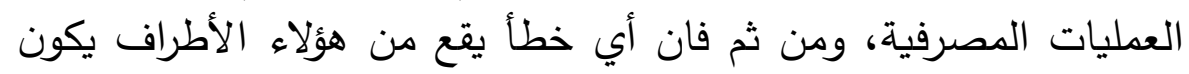

البنك مسؤوليه عنه (").

نوع ومعيار الخطأ العقدى للبنك في عقد تحصيل الأوراق التجارية.

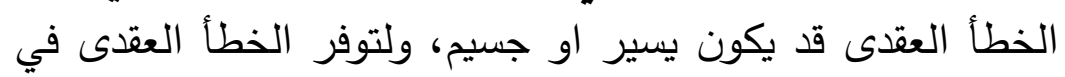

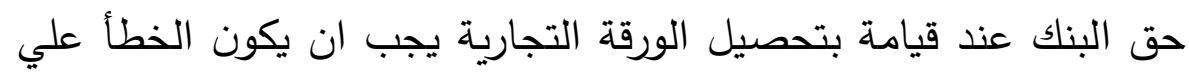

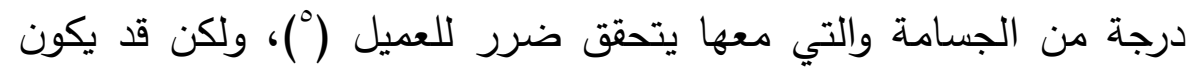

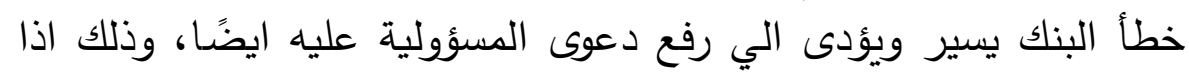

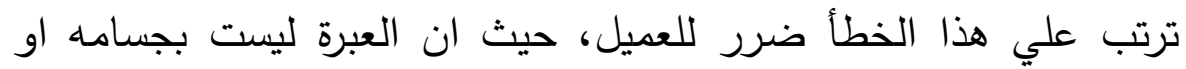
بساطة الخطأ الذي يرتكبه البنك، بقدر ما تكون العبرة بمدى تحقق ضرر

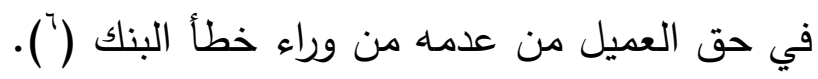
اما عن معيار الخطأ العقدى للبنك في عقد تحصيل فيل الأوراق

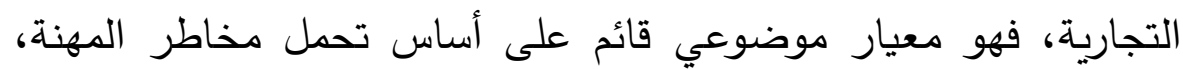

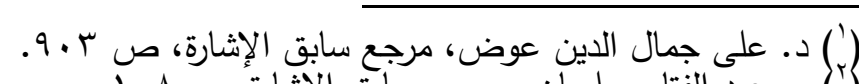

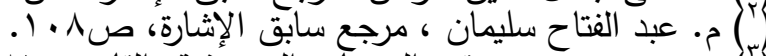

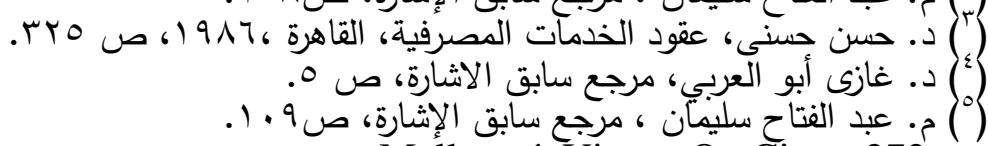

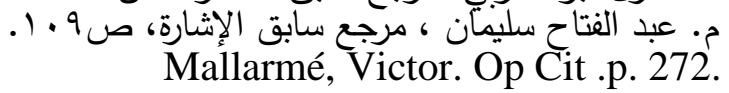


حيث يقارن فيه مسلك البنك بالمسلك المعتاد لبنك اخر مماثل له، ويمثل أي انحراف عن ذلك المسلك خطأ يستوجب معه قيام دعوى المسؤولية علي البنك من قبل العميل ('). اثبات الخطأ العقدى للبنك.

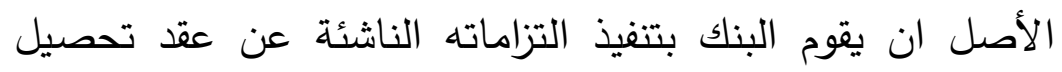

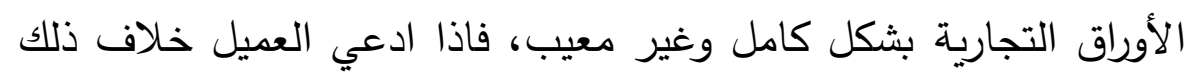

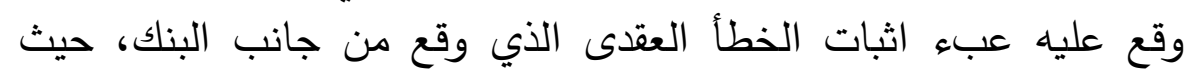

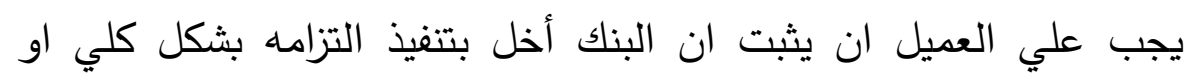

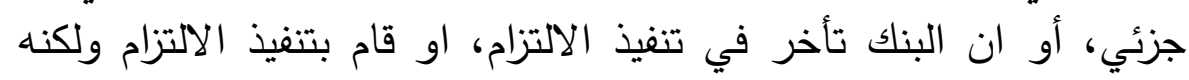
تنفيذ معيب، او لم يبذل العناية المطلوبة في تنفيذ عقد تحصيل الأوراق

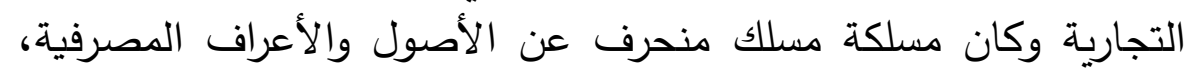
وللعميل ان يثبت ذلك بكافة طرق الاثبات القانونية.

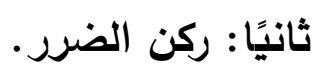

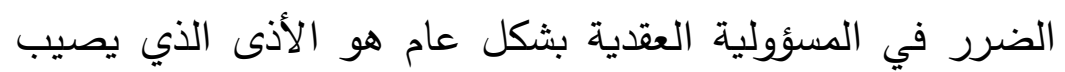

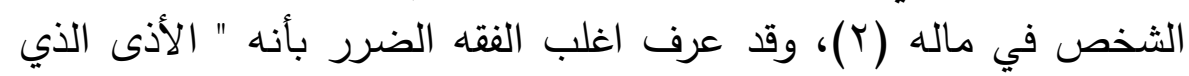
يصيب الثخص في حق من حقوقه او مصلحه مشروعه لله، سواء كانت

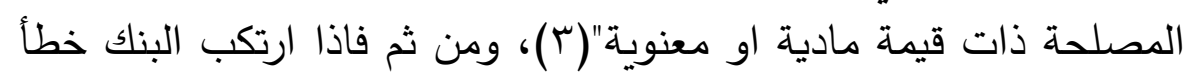

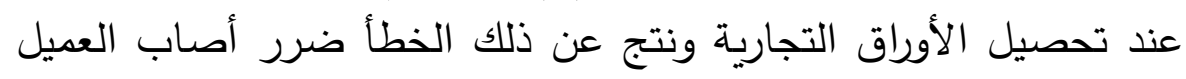

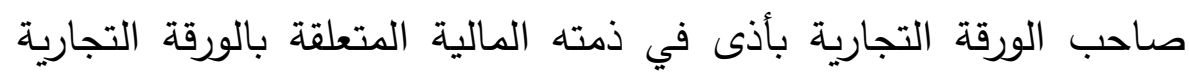

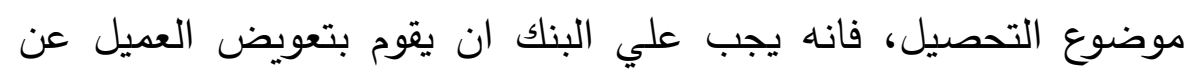
ذلك الضرر • موضوع

وبالطبع فانه يجب ان يثبت العميل ان الضرر الذي وقع عليه

كان بسبب خطأ البنك وبالتالي يجب انه يث يثبت العميل خطأ البنك اولاً، ولكن الواقع العملي في ذلك الأمر اثبت صعوبة اثبات العميل خطأ البنك الك الكال

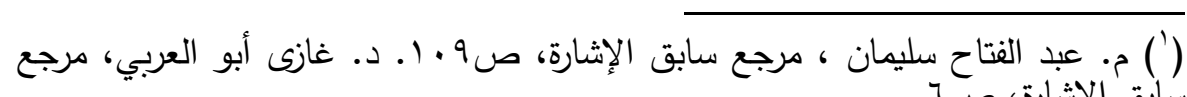

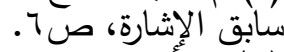

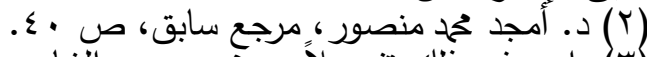

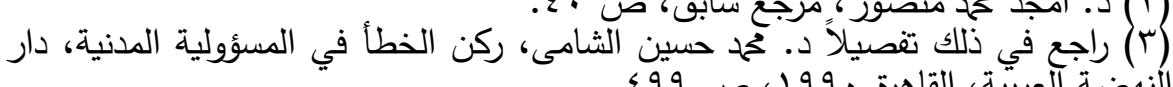

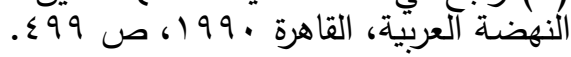


في اغلب الأحيان(')، وبالتالي عدم قدرة العميل اثبات الضرر وعدم

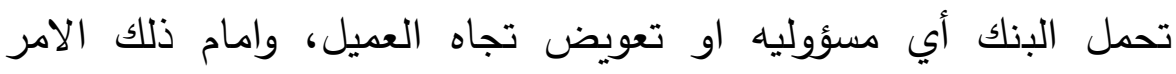
وحماية للعميل الذي يعد هو الطرف الأضعف في عقد تحصيل الأوراق

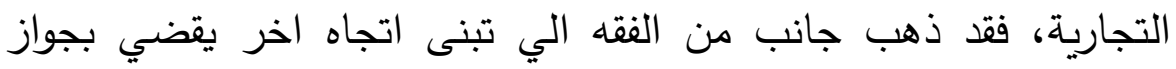

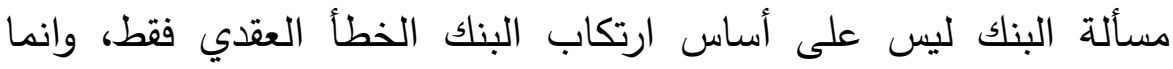
يكفي فقط وقوع ضرر علي العميل.

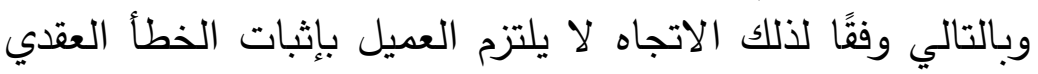

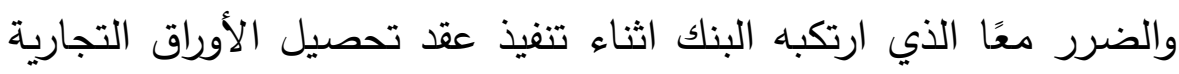

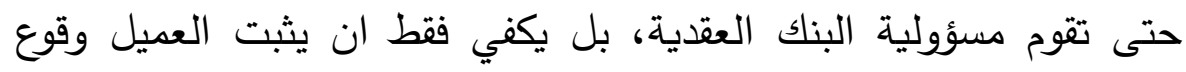

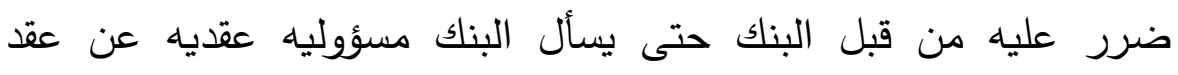

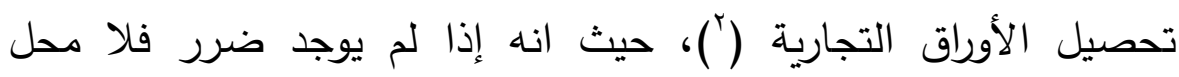

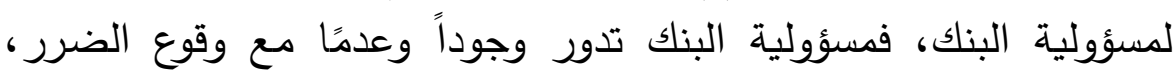

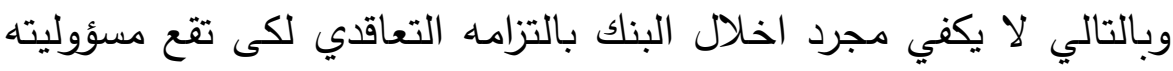

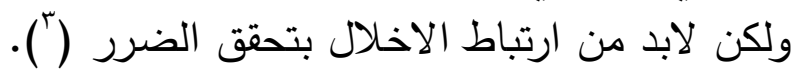

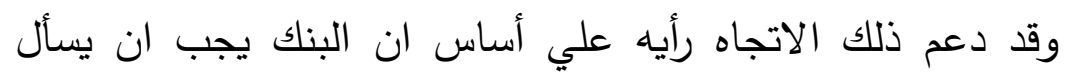

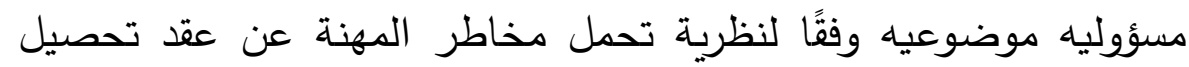

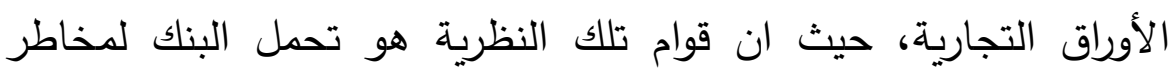
مهنته باعتباره ليس شخص عادى، وانما هو شخص محترف في في القيام

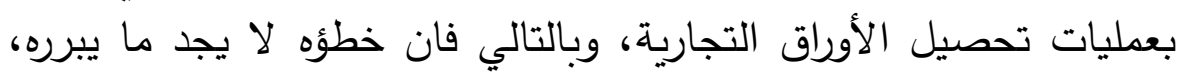

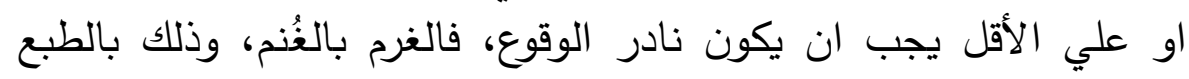
يحقق حمايه فاعله واكبر للعميل (ع).

(1) وترجع صعوبة اثبات العميل خطأ البنك العقدي الناتج عن عقد تحصيل الأوراق

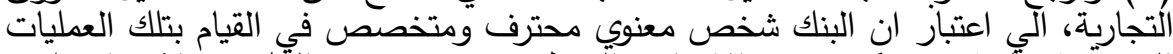

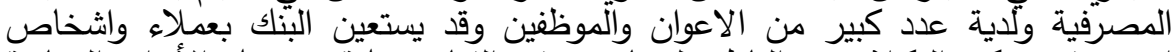

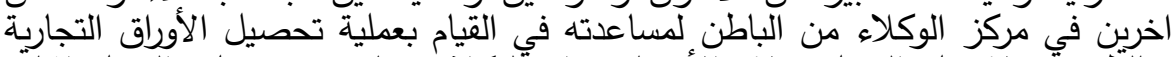

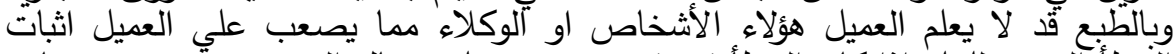

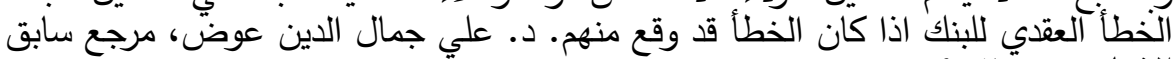

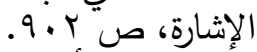

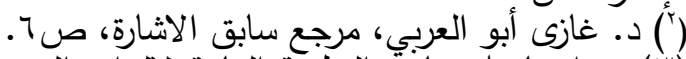

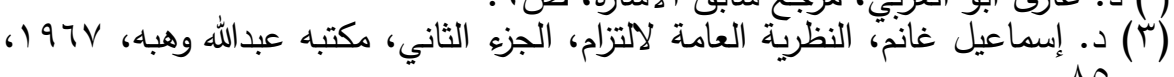

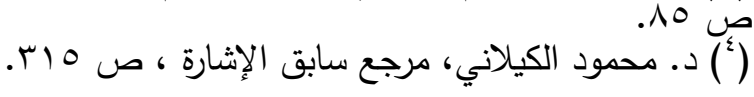




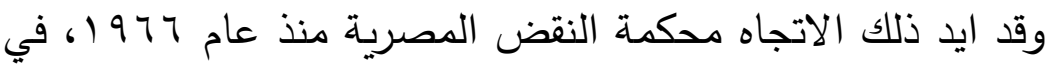

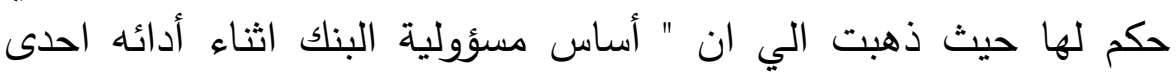

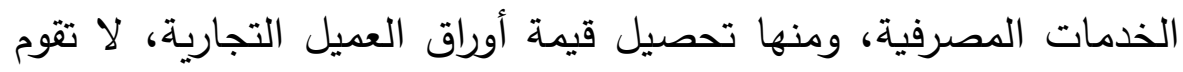

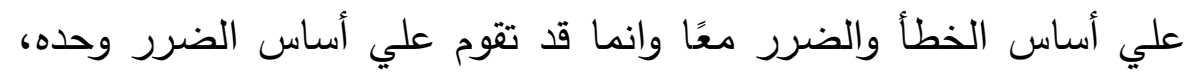

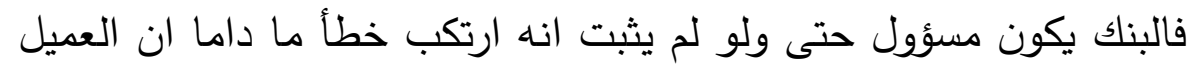
قد أصابه ضرر، وان هذا الضرر ليس ناتج بسبب خطأ العميل، وقضت

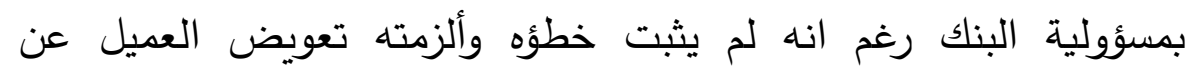

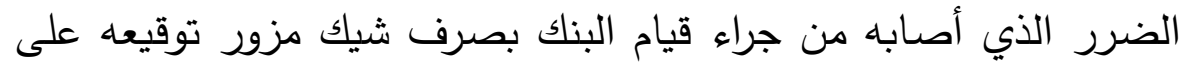
العميل" (1). وبهذا تكون محكمة النقض المصرية قد أخذت بالمسئولية

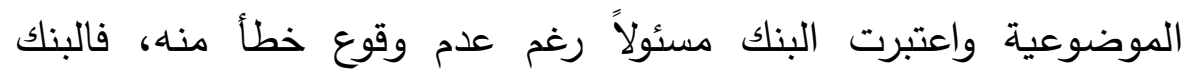
مسؤول عن الضرر الذي يصيب العميل من جراء نشاطه ولو لم يكن فئن

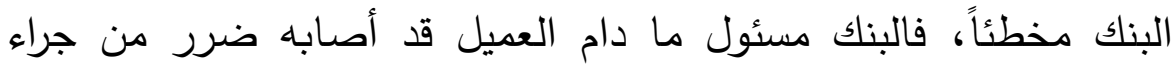

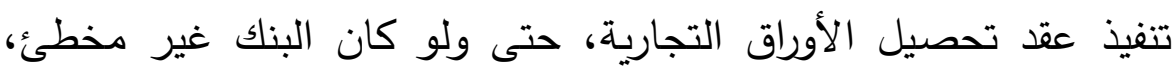

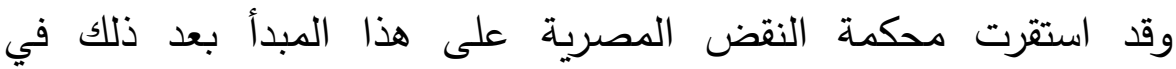

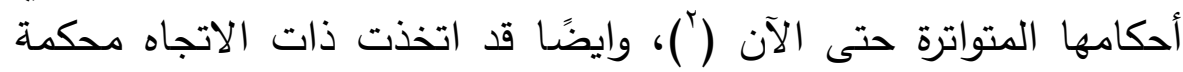
النقض الفرنسية وسبقت محكمة النقض المصرية في احكامها منذ عام . ( () ) 1949

وعلى ذلك فالضرر قد يكون هو الركن الوحيد لمسئولية البنك في

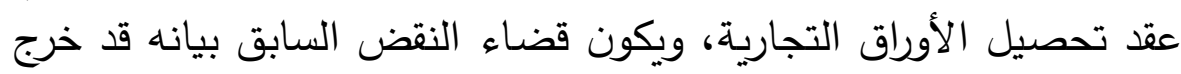
عن القواعد العامة في المسئولية المدنية في القانون المدني واخذ ونذاء بمسئولية المخاطر، وعلة ذلك أن محكمة النقض المصرية في غيبة التشريع الخاص بالبنوك - وقت صدور هذا الحكم اجتهدت وسايرت الاتجاه

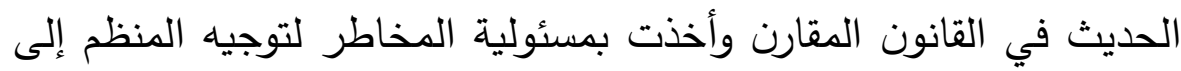
ضرورة التذخل لإصدار تشريع خاص بالبنوك ينص فيه على مسئولية

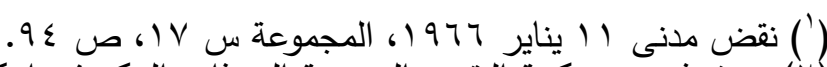

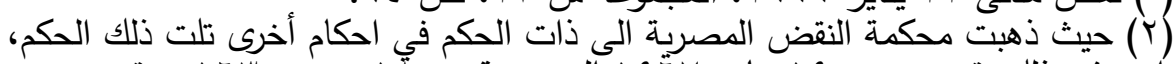

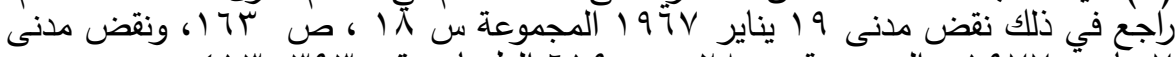

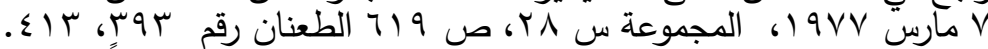

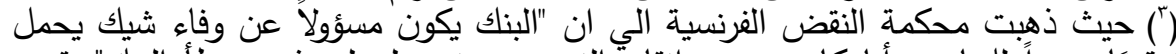

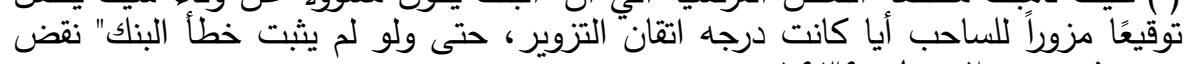

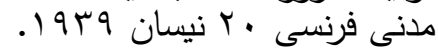


البنك في نشاطه مسئولية موضوعية مبناها فكرة المخاطر وتحمل التبعة.

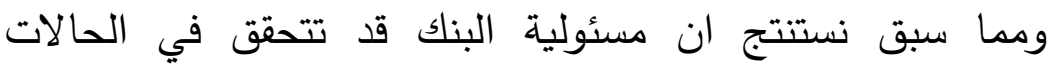

- إذا وقع ضرر للعميل من جراء خطأ البنك طبقاً للقواعد العامة. - إذا أصيب العميل بضرر من جراء تنفيذ البنك لعقد تحصيل الأوراق التجارية ولو لم يكن هذا الضرر ناتجاً عن خطأ العميل (').

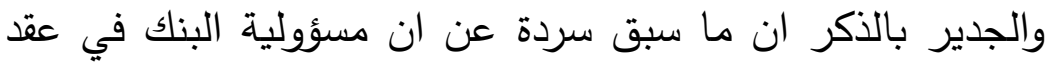

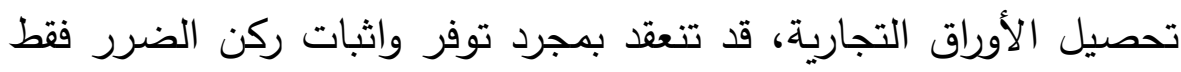

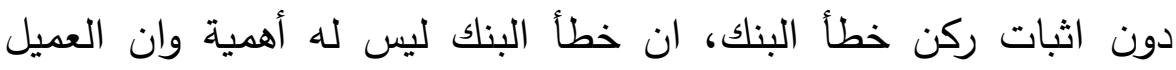

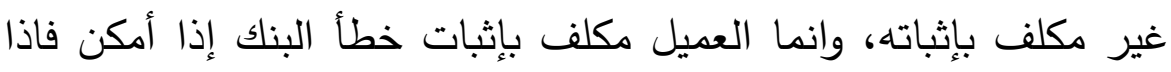
تعذر عليه ذلك، يجوز له اثبات ركن الضرر فقط دون ركن الخطأ خروجًا

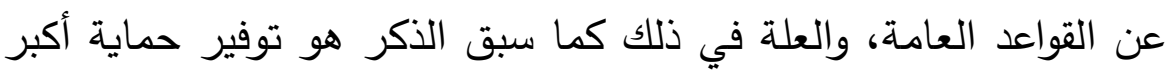
للعميل في مواجه البنك. • تعويض البنك للعميل عن الضرر الناشئ عن عقد تحصيل الأوراق

$$
\text { التجاريـة. }
$$

إذا اثبت العميل انه أصيب بضرر بسبب خطأ البنك الناتج عن

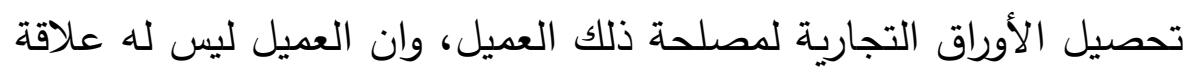

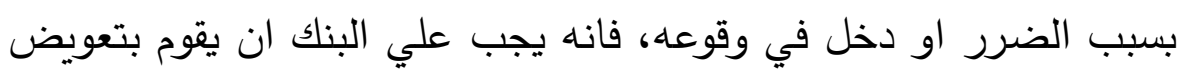

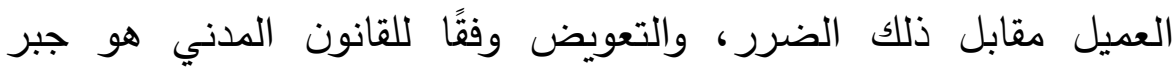
الضرر الذي يلحق بالمضرور ، ولكى يقوم البنك بجبر الضرى ولفر ويتحمل

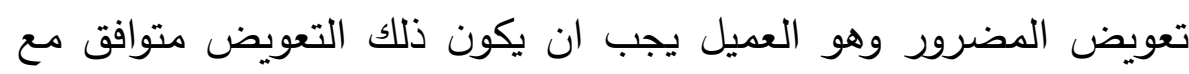

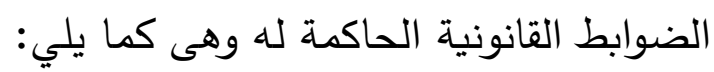

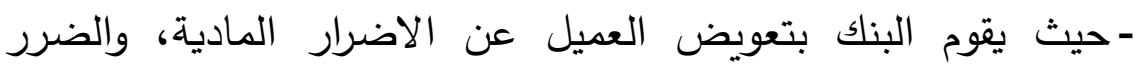
المادي هو كل مساس يصيب العميل بخسارة ماليه، ويعد هذا الضرر الضرار

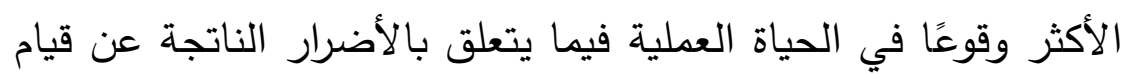

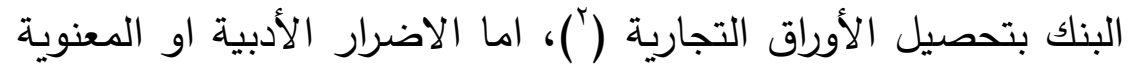


وهى ما يصيب الثخص في سمعته وشرفه من اذي (')، ففي الغالب

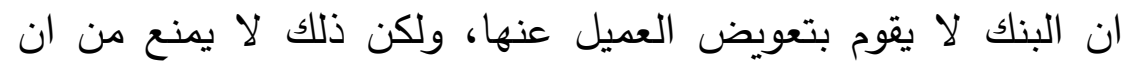

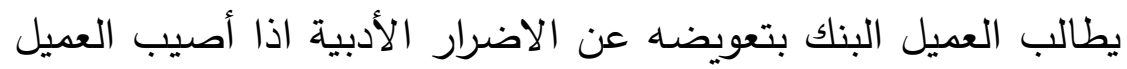

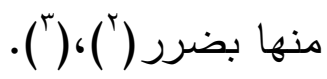

- كذلك فان البنك يقوم بتعويض العميل في عقد تحصيل الأوراق

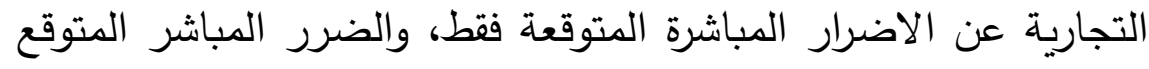

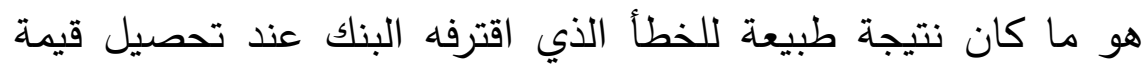

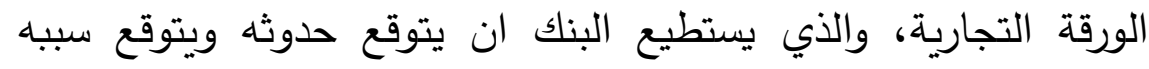

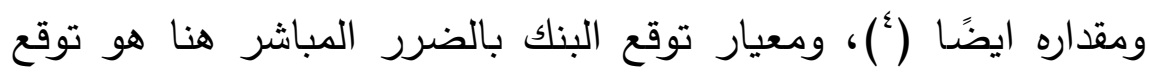
بنك اخر محصل مماثل لله في ذات الواقعة (")، فمعيار توقع قياس

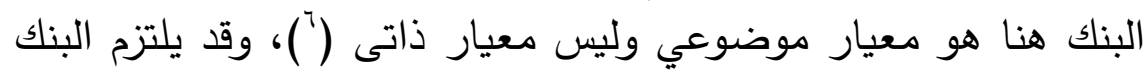

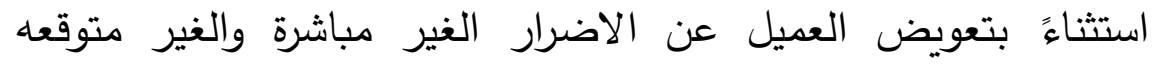

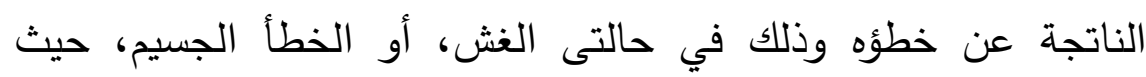

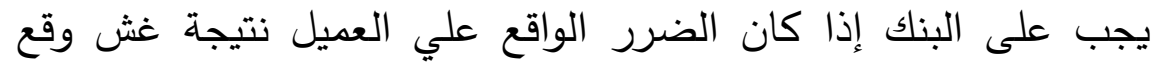

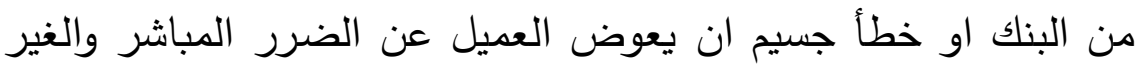

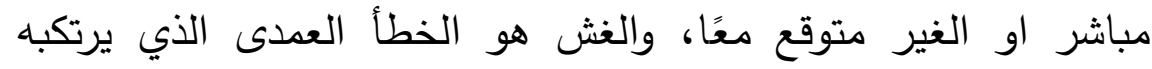
البنك بانصراف ارادته عن عمد بالقيام بفعل محدد عند تحصيل قيمة ولفيلة

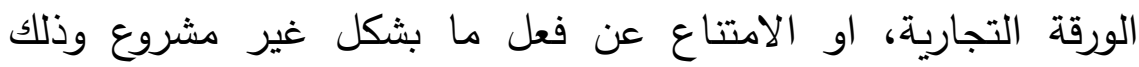

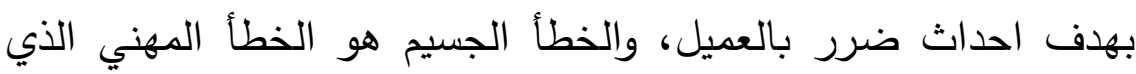
يقع من البنك بقصد او دون قصد دون مبرر مقبول، ويبلغ ذلك الخطأ

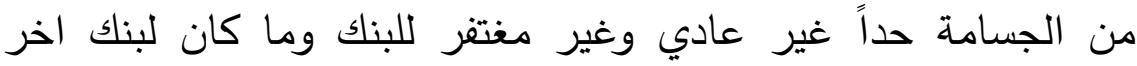

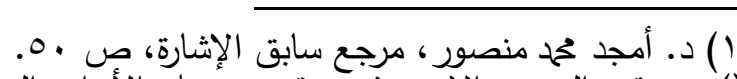

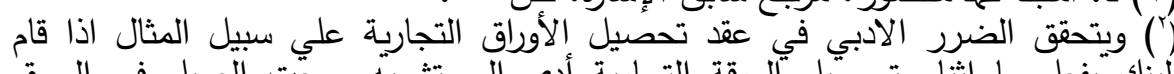

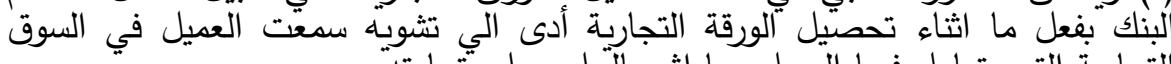

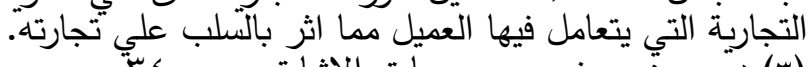

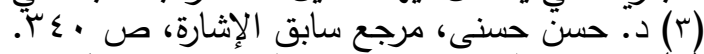

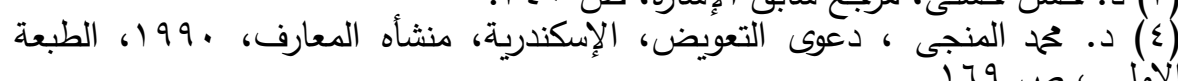

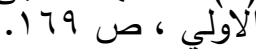

5) (Y.Buffelan.Lanore, Doroit, Civil, 3e edition. Masson.19986. paris. p. 251.

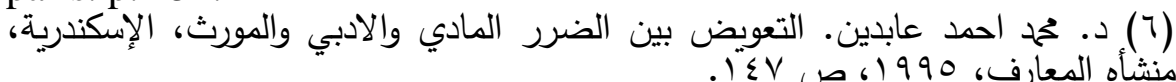


مماثل له الوقع في ذلك الخطأ، ومثال ذلك جهل البنك الفاضح بالمبادئ الأساسية للعمل المصرفي المتعلقة بتحصيل الأوراق التجارية

- كما يجب حتى يقوم البنك بتعويض العميل عن الضرر الناتج عن

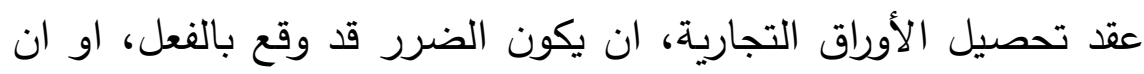

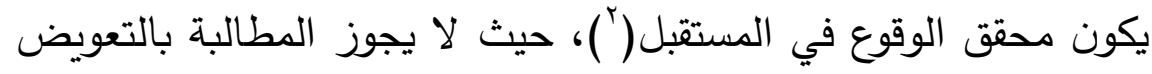

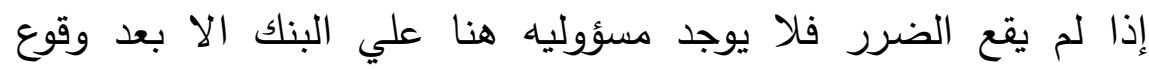

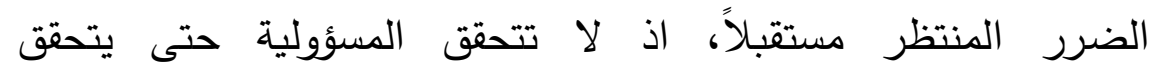

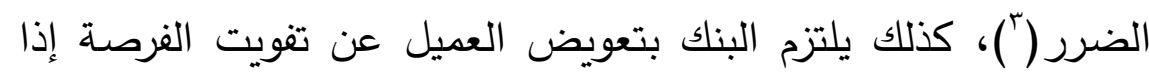

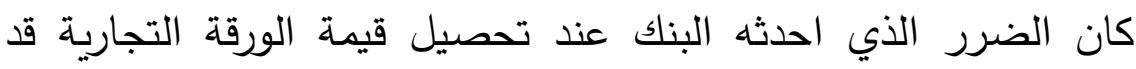
أدى الي ضياع فرصه مؤكدة ومحققه الوقوع للكسب علي العميل

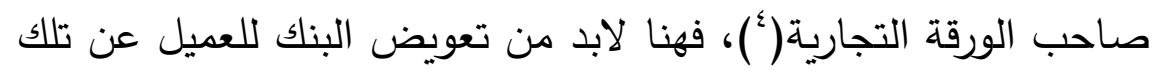

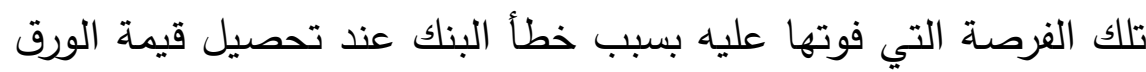

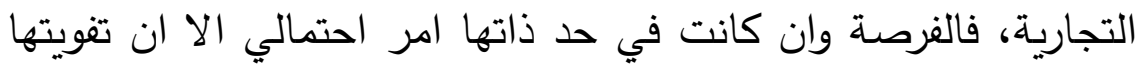
المؤكد يستلزم قيام البنك بتعويض العميل عنها، وهذا ما استقر عليه

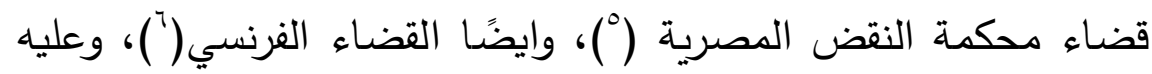
وعليه يمكن للعميل المطالبة بالتعويض عن تفويت البنك عليه فرصده

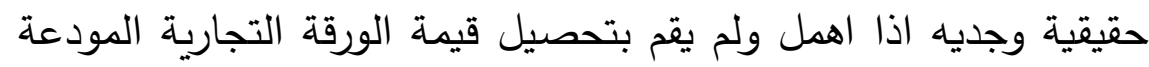
لديه خلال المدة القانونية، وكان العميل قد اعتمد علي قيمه تلك الك الورقة التي سيقوم البنك بتحصيلها في الدخول في مناقصه، او شراء صفقانه

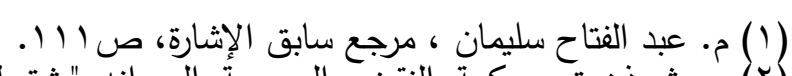

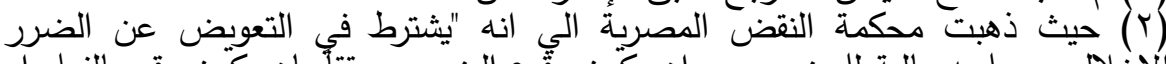

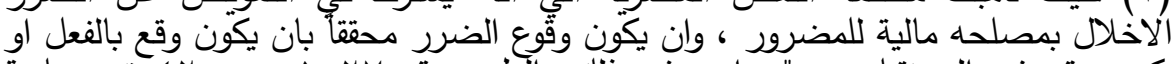

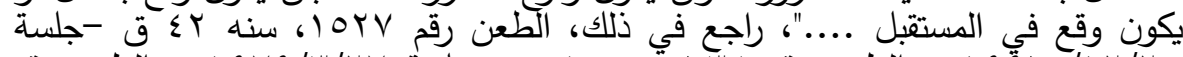
.

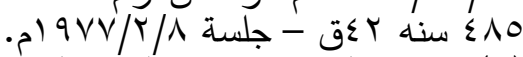

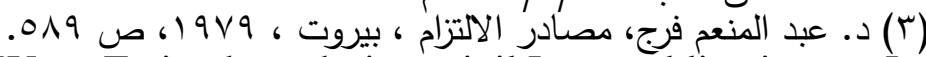
4) (G.VINEY. Traite.de droit civil,Les obligations La responsbilite:conditions, L.G.D.J.paris.1982. No.279. p.343.

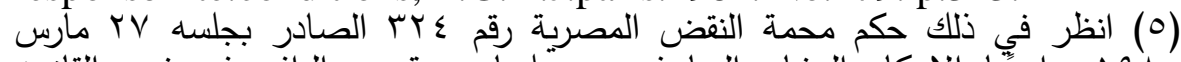

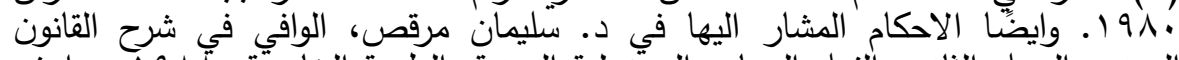

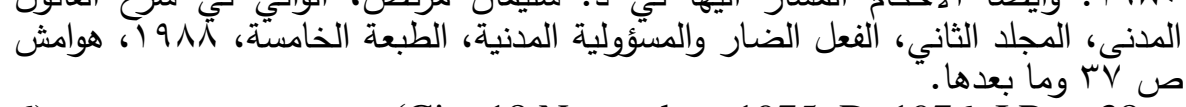

(Civ, 18 November. 1975. D. 1976. I.R. p.38. 


$$
\text { تجاريه كان مؤكد فيها حصول العميل علي ربح ('). }
$$

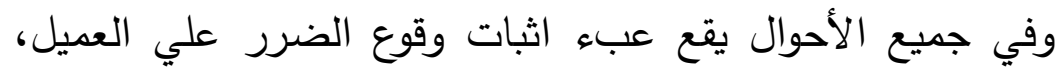

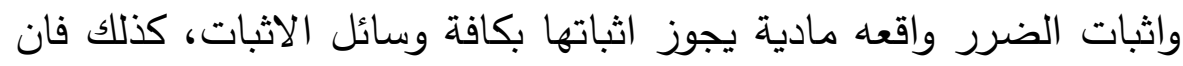

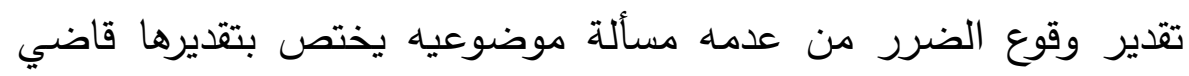

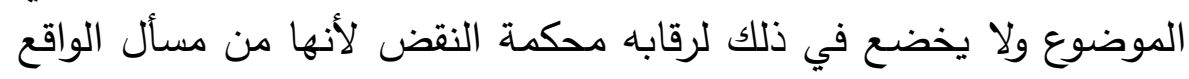
وليست من مسأل القانون.

والتعويض يكون بمقدار الضرر الواقع علي العميل ولا يكون بدرجه الخطأ، ودائمًا ما يكون التعويض مبلغ نعلن نقدي.

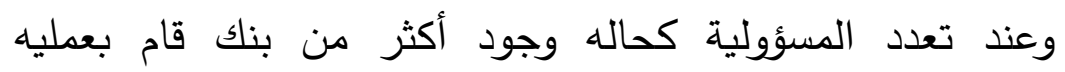

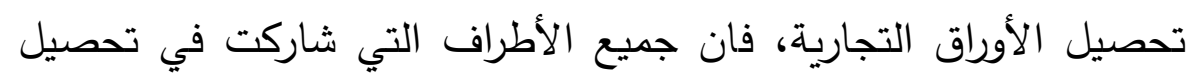

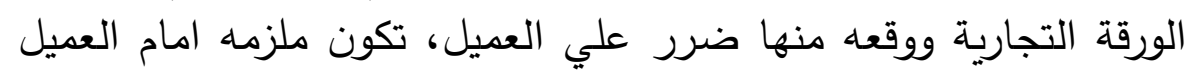

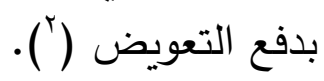
ثالثًا: علاقة السببية بين خطأ البنك وضرر العميل.

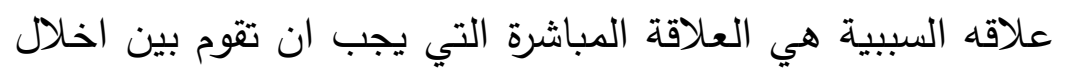

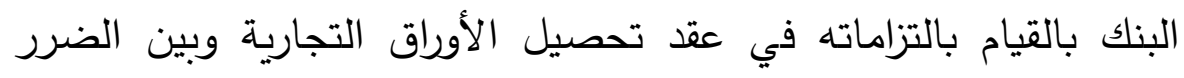

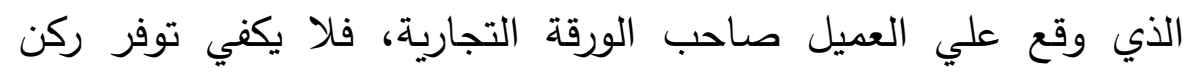
الخطأ الواقع من البنك وركن الضرر فقط، بل يجب لإن لانعقاد مسؤوليه

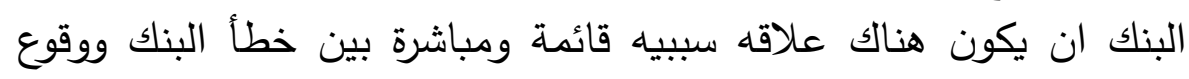

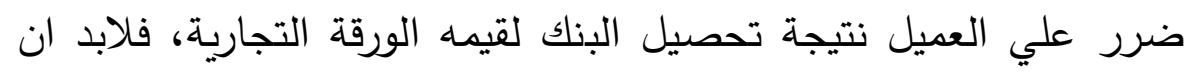
يكون خطأ البنك واخلاله بالتزاماته هو السبب المباشر في احداث الضرل الضرر الواقع علي العميل، ومن ثم فان انتفاء رابطه السببية يؤدى الي انتفاء

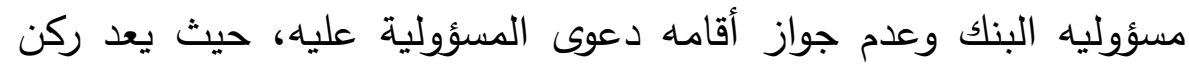

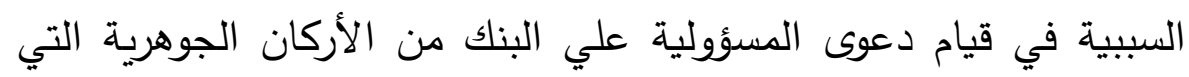

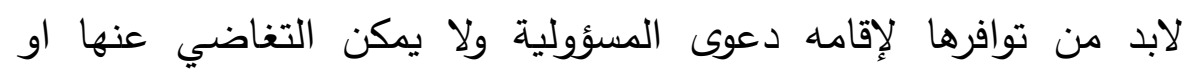

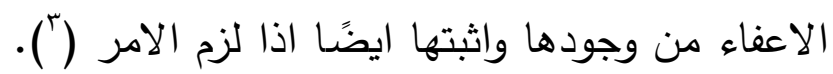

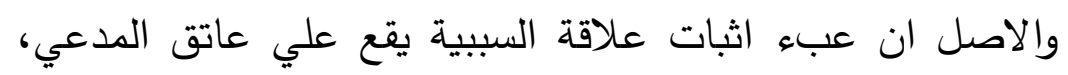


فاذا ادعي العميل وقوع ضرر عليه بسبب اخلال البنك بالتزاماته التي

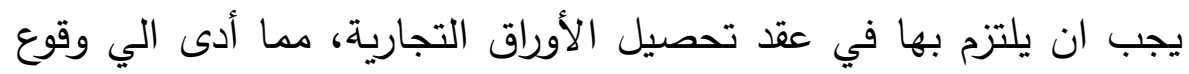

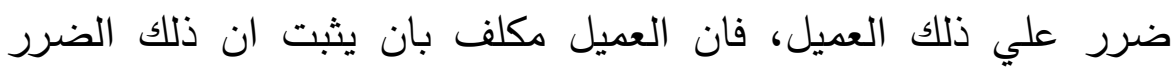
المباشر الذي وقع عليه قد وقع بسبب اخلال البنك بالتزاماته، ولا يجد

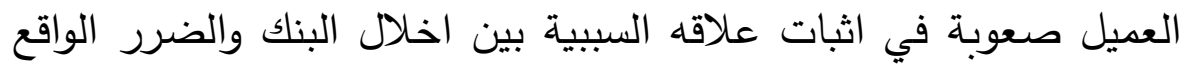
عليه لإقامه دعوى المسؤولية علي البنك، فبمجرد ان يقوم العميل بإثبات الضرر ويقدم القرائن التي ترجح قيام علاقه السببية طبقًا لمبدأ الاحتمال

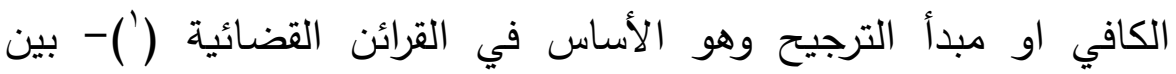

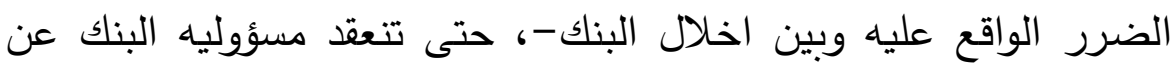
خطأه الناشئ عن قيامه بتحصيل قيمة الأوراق التجارية.

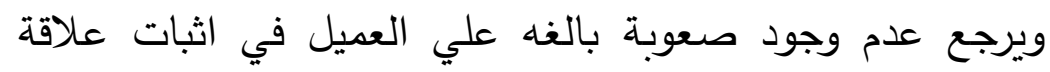

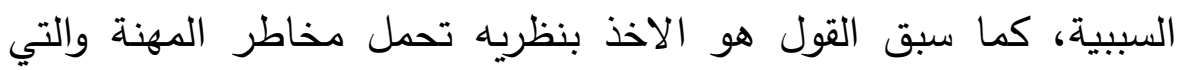
اوسعت من نطاق مسؤوليه البنك تجاه العميل في عقد تحصيل الأوراق

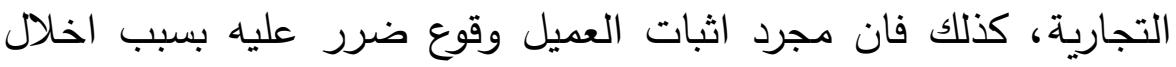

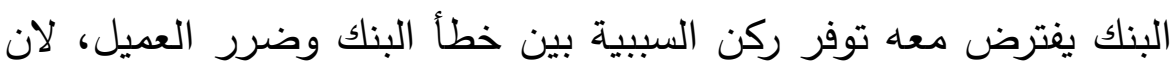

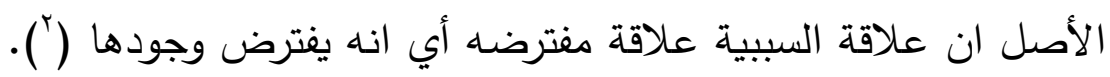

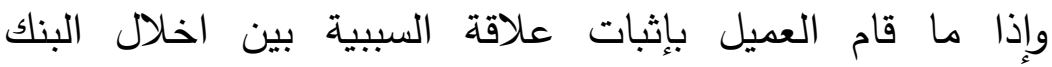

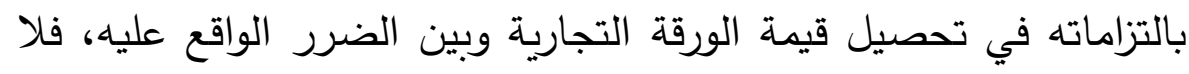

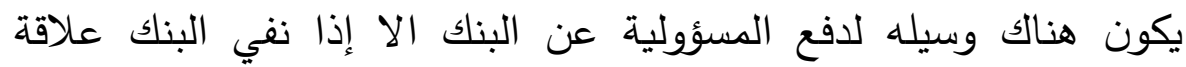

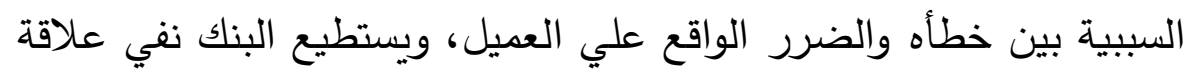

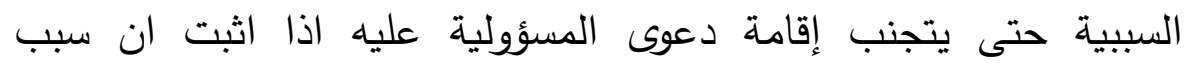

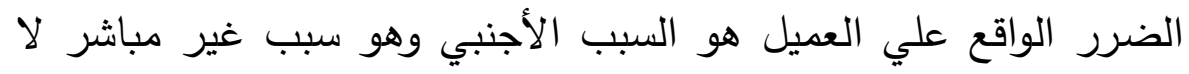

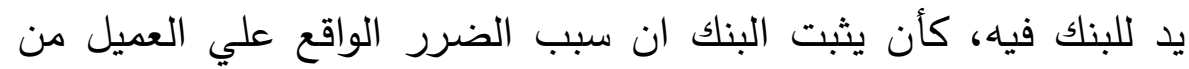

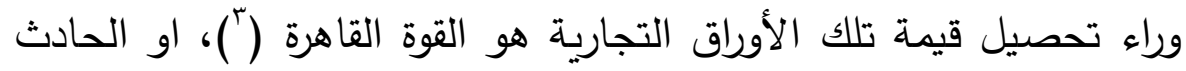

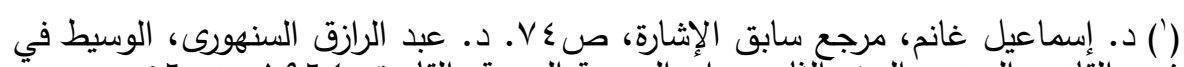

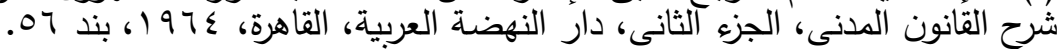

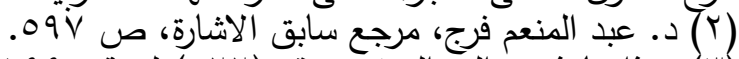

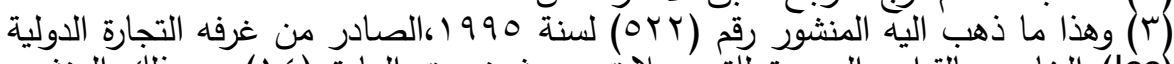

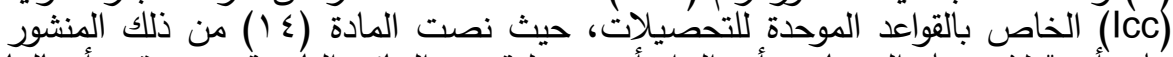
علي أنه " لا تتحمل المصارف أي التزام أو مسؤولية عن النتائج الناجمة عن توقف أعمالها 
المفاجئ، او الآفة السماوية، او فعل الغير (')، وبذلك تنتفي مسؤوليه البنك عن أي اخلال وقع عند تحصيل قيمة الأوراق التجاريـة.

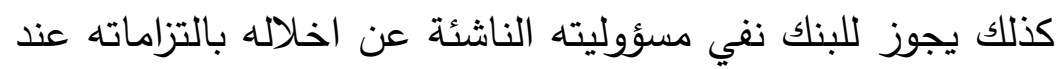

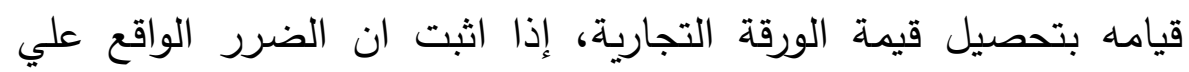

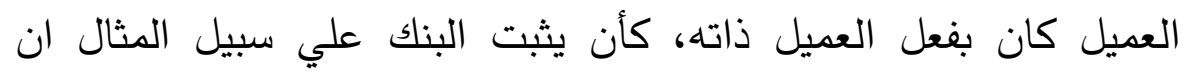

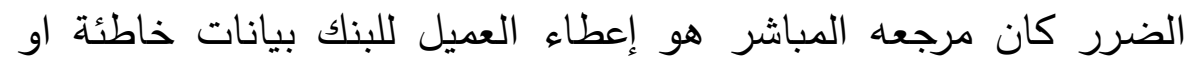

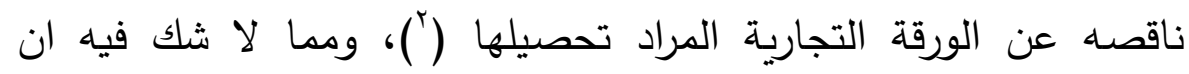

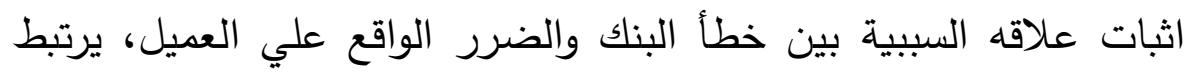

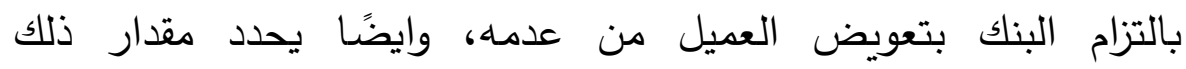

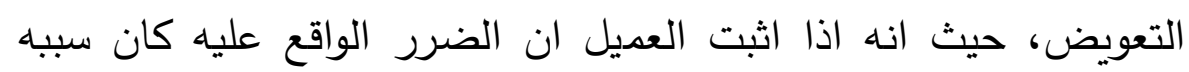

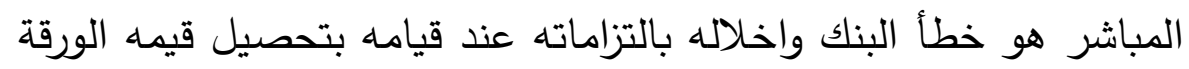

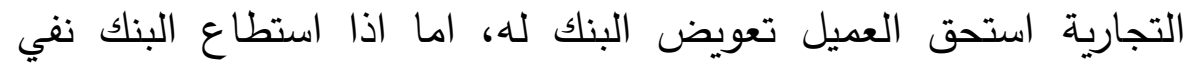
علاقه السببية لأي سبب من الأسباب بين اخلاله بتنفيذ التزاماته وبين

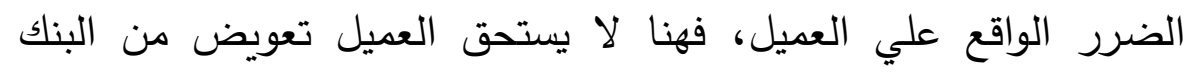

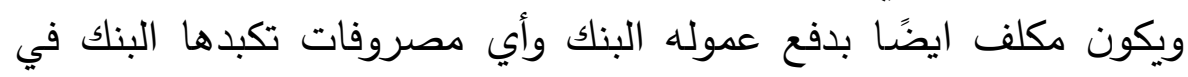

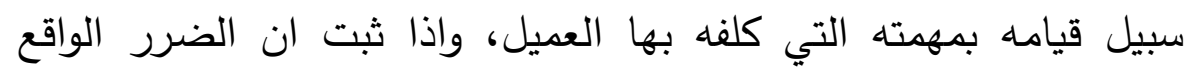

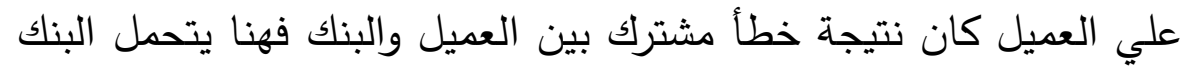

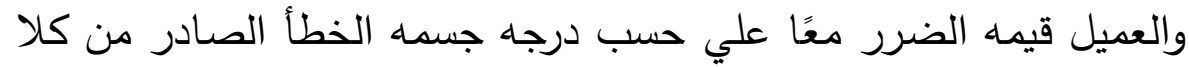

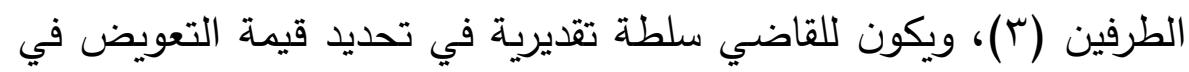

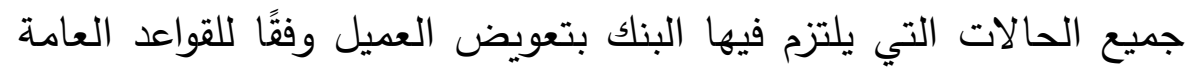

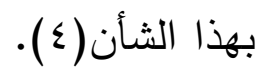

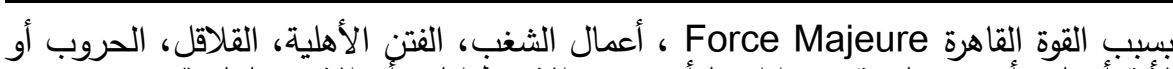

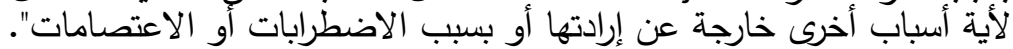

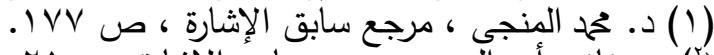

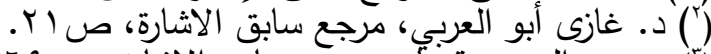

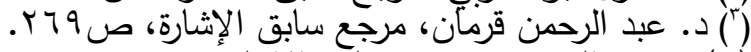

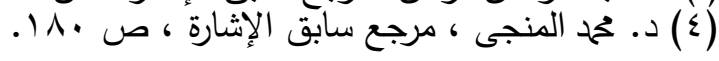




\section{المبيثث الثالث}

\section{حالات انعقاد مسوولية البنك الناشئة عن عقد تثصيل الأوراق التجارية والاعفاء منها}

\section{تمهيد وتقسيم.}

كما سلف الذكر فأن اخلال البنك بالتزاماته المتولدة عن عقد ألمات تحصيل الأوراق التجارية هي في جوهرها أساس انعقاد مسؤوليته، وتبدأ

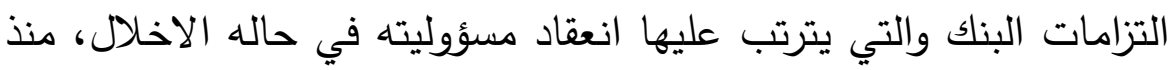
تسلم الورقة التجارية من العميل بموجب عقد تحصيل الأوراق التجارية، وحتى تنتهى عمليه التحصيل ويتم تنفيذها بالكامل، ثم إعادة البنك الورقة

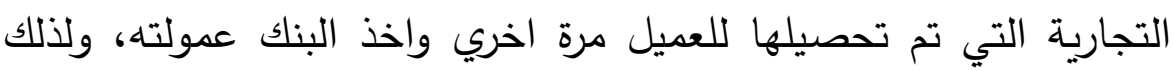

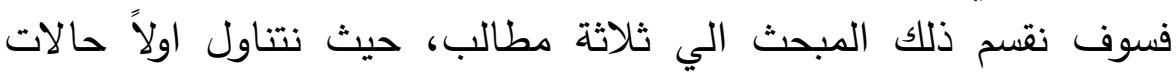

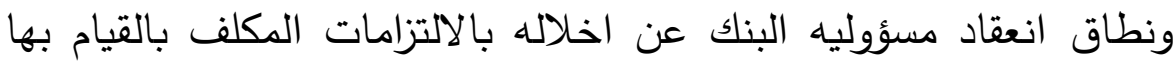

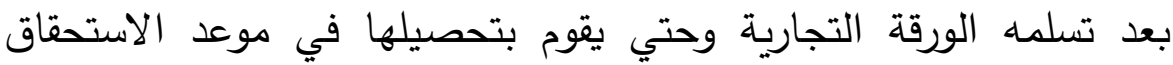

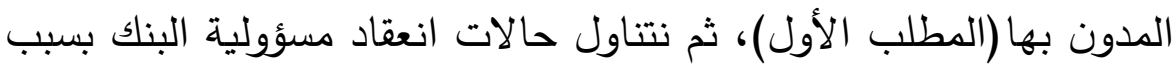
اخلاله بالتزاماته الواجب عليه القيام بها بعد تحصيل قيمة الورقة التجارية

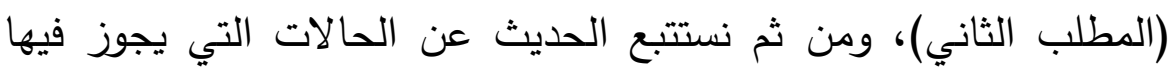
اعفاء البنك من المسؤولية الناشئة عن عقد تحصيل التعائ الأوراق التجارية ومدي صحه ذلك الاعفاء ونطاقه (المطلب الثالث).

\section{الإطبا الأول}

\section{نطاق هسؤوليه البنـك هنذ تسلم الورقة التبارية وحتى تصصيلها}

يقع علي عاتق البنك القيام بمجموعه من الالتزامات عند ابرام

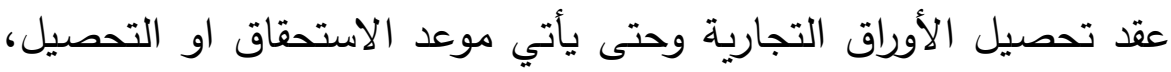

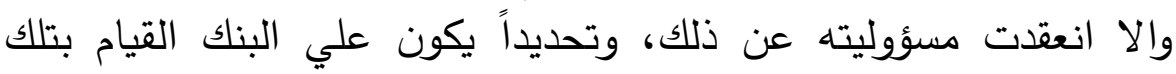

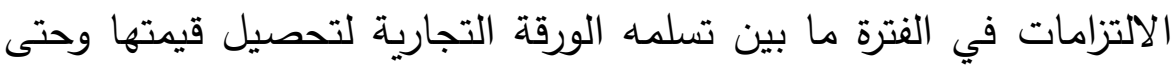

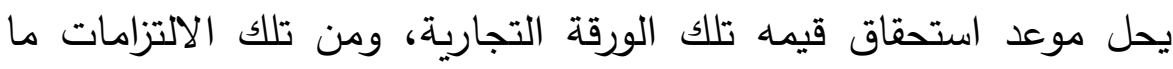

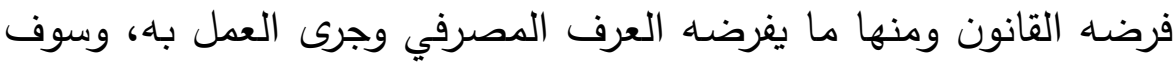
نوضح فيما يلي نطاق حالات انعقاد مسؤوليه البنك منذ ان يتسلم الورقية

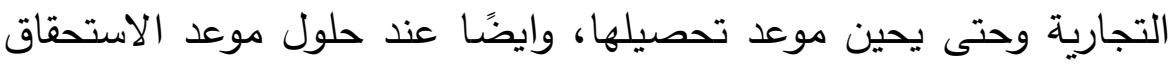


اذا ما اخل البنك بالتزاماته في تلك المرحلة، وترتب علي ذلك الخلل

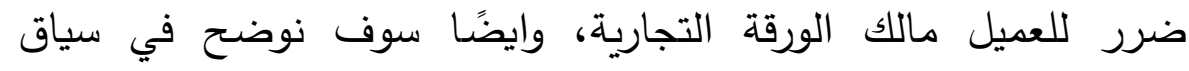

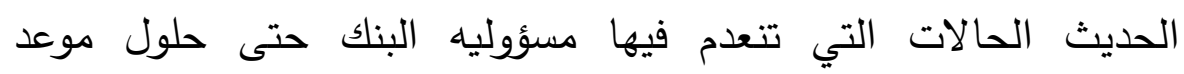
استحقاق او تحصيل الورقة التجارية. اولاً: مسؤوليه البنك عن عدم تسلم الورقة التجارية محل عقد التحصيل.

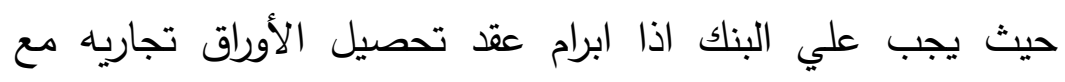

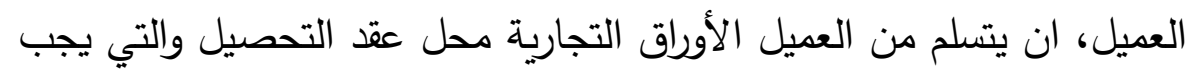

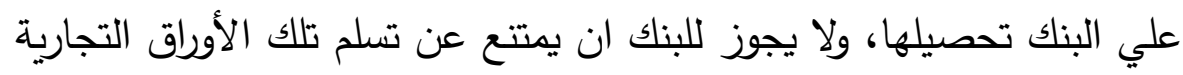
او يرفض تسلمها، والا جاز للعميل ان يقيم عليه دعوى المسؤولية ويطالبه

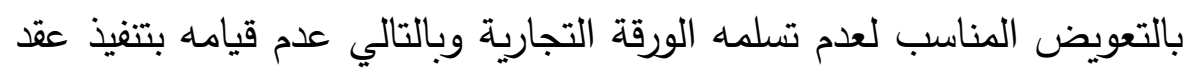

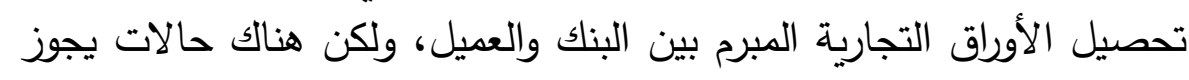

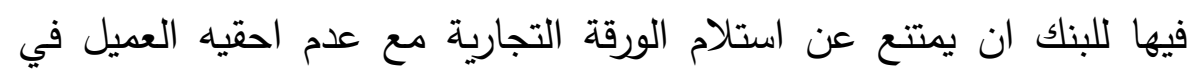

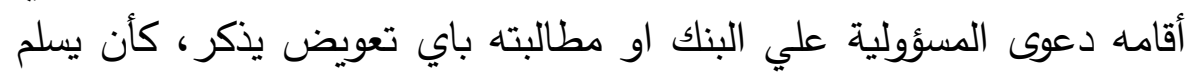

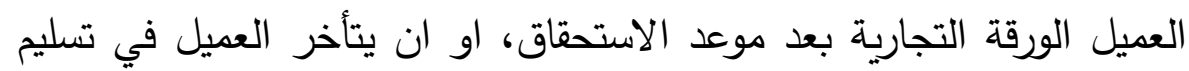

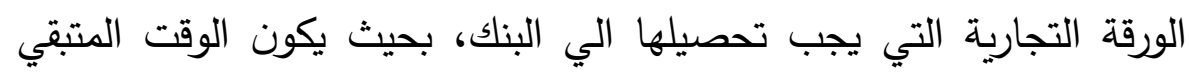

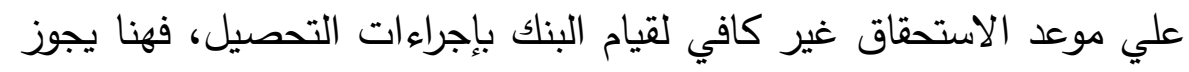

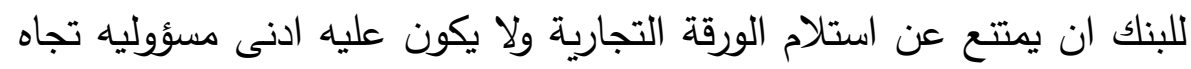

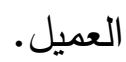

ثانيًا: مسؤوليه البنك عن علم المحافظة المادية علي الورقة التجاريـة.

حيث ان العميل يجوز لله إقامة دعوى المسؤولية علي البنك اذا اخل

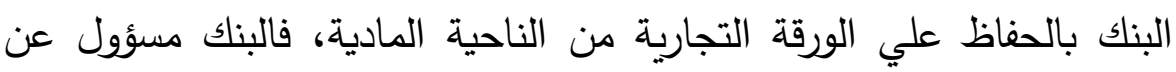

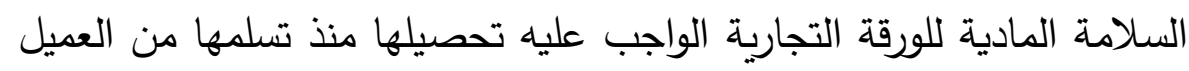

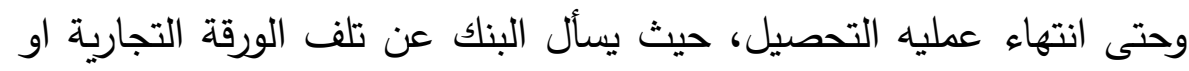

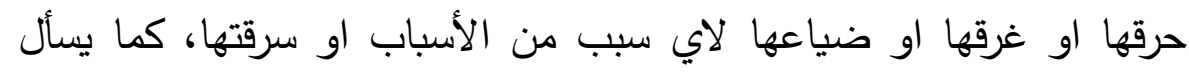
البنك عن أي عبث يحدث ببيانات الورقة التجارية مثل محو بعض البيات البانات اونيات

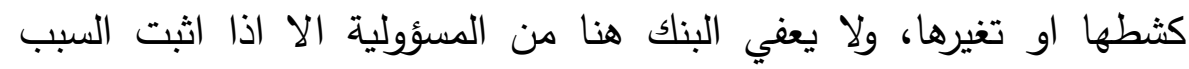


الأجنبي(')، ويستوى ان يكون عدم الحفاظ علي الورقة التجارية تسبب فيه احد

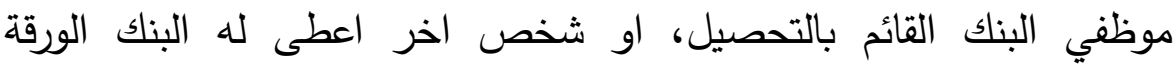
التجارية لمعاونته في تحصيلها ثم تسبب ذلك الثخص في في هلاك الورقة التها

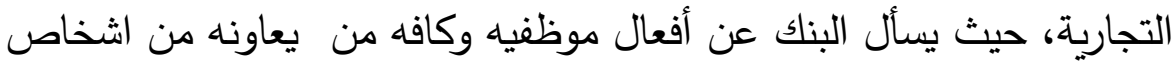
في تنفيذ عقد تحصيل الأوراق التجارية.

ثالثًا : مسؤوليه البنك عن عدم تقديم الورقة التجارية للقبول.

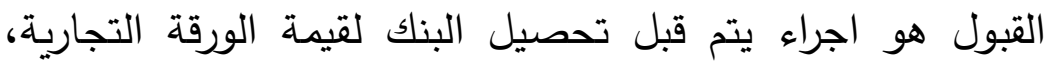

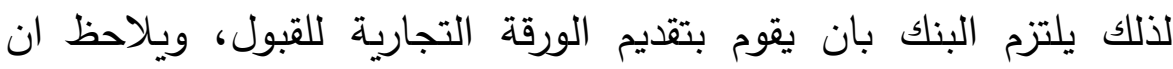

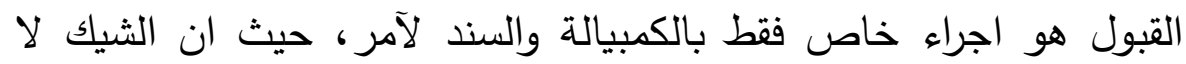

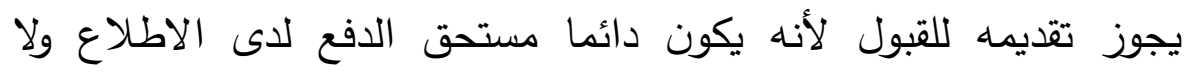

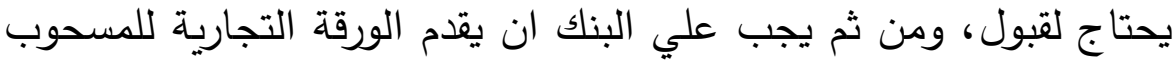

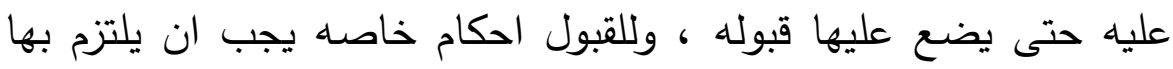

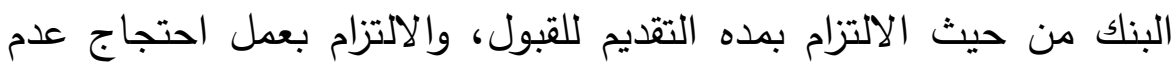

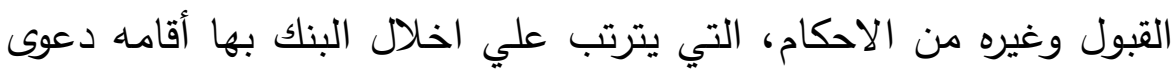

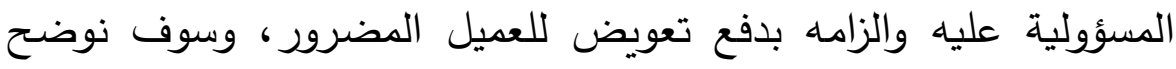
نطاق مسؤوليه البنك فيما يتعلق بتقديم الورقة التجارية للقبول فيما يلي: لمعيد

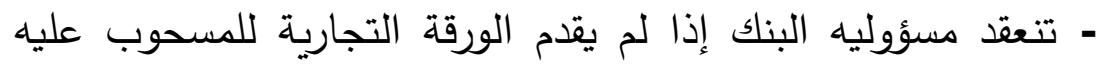
لقبولها في المواعيد المحددة وقبل فوات موعد القبول متى كان القبول واجبًا، وبشكل عام فان موعد القبول يكون من وقت سحب فولت الورقة

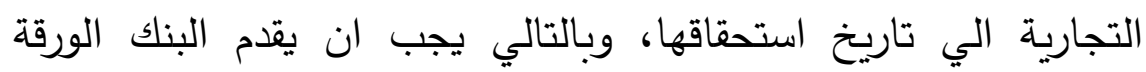

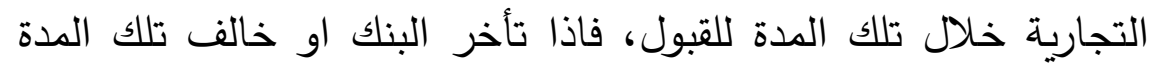
فانه يكون مسؤول في مواجهه العميل إذا ترتب علي ذلك ضرد ضرد للعميل، ويلاحظ ان البنك مسؤول عن تقديم الورقة التجارية للقبول المستحقة الوفاء بعد مضىى مدة معينة من الاطلاع عليها خلال سنة

(') د. غازى أبو العربي، مرجع سابق الاشارة، صعـ (. 
من تاريخها، وبالطبع لا يكون البنك ملزم بتقديم الورقة التجارية للقبول اذا كانت مستحقه الدفع بمجرد الاطلاع (').

- كذلك تنعقد مسؤوليه البنك إذا تضمنت الورقة التجارية موعد

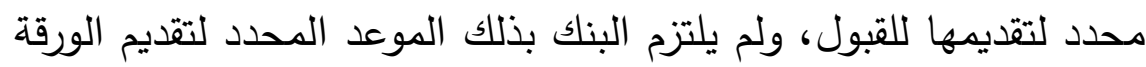

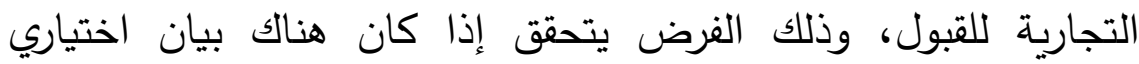

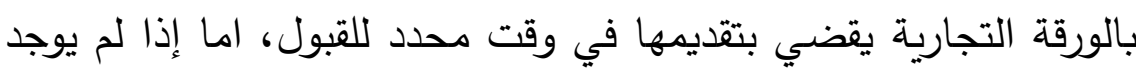

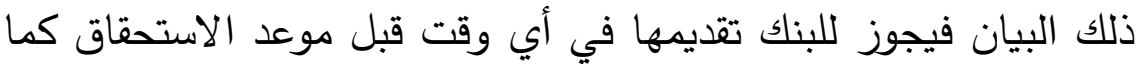

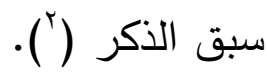
- كما تتعقد مسؤوليه البنك إذا رفض القبول الجزئي للورقة التجارية،

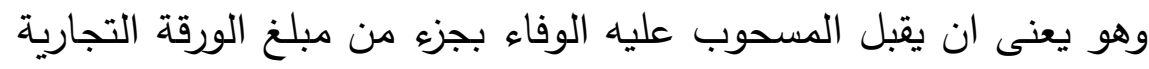

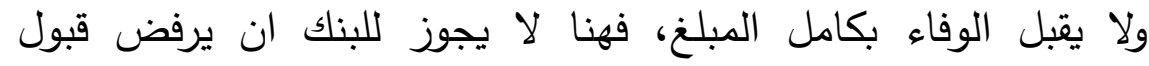

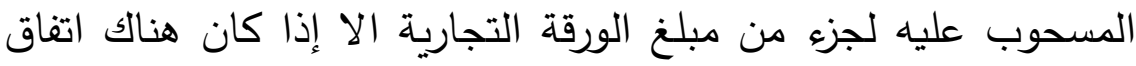

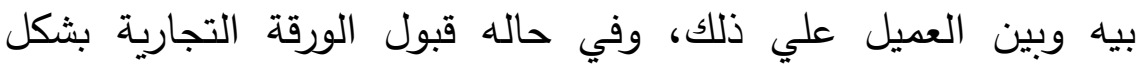

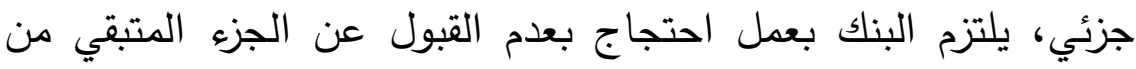

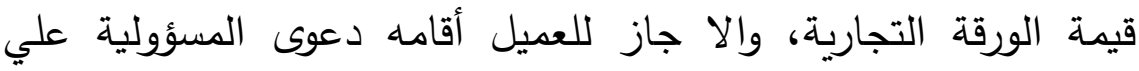
البنك إذا وقع علي ذلك العميل ضرر (ب).

- كذلك فان البنك يسأل عن صحة شكل القبول، حيث لا يجوز

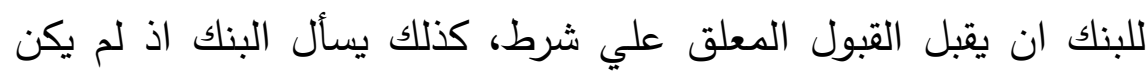

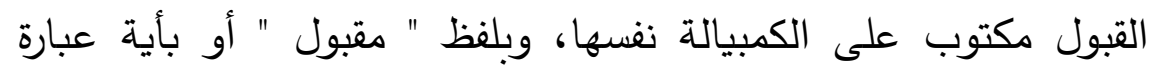

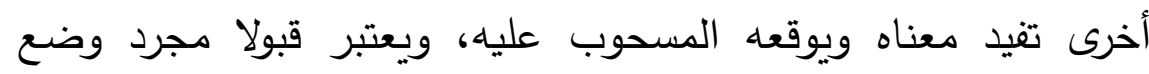

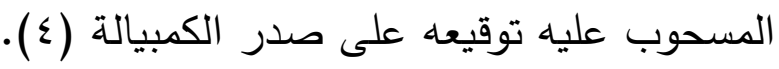

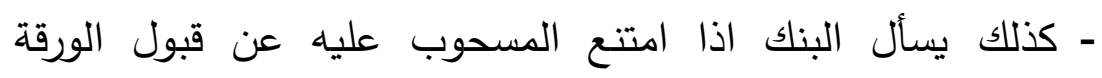
التجارية او رفض قبولها، ولم يقوم البنك بعدها بعمل احتجاج بعدم الكابه

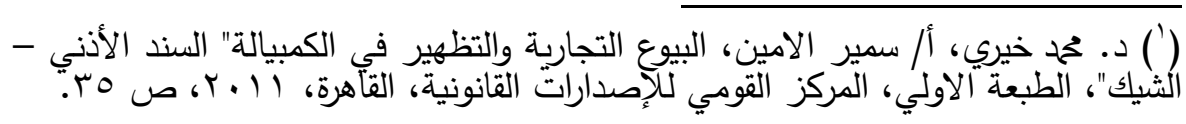

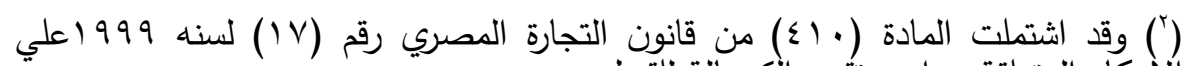
الآكام المتعلقة بمواعيد تقديم الكمبيالة للقبول.

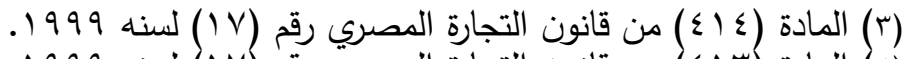

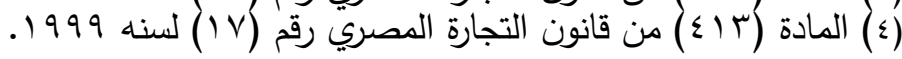


القبول اذا ترتب علي ذلك وقوع ضرر للعميل او كان هناك تعليمات

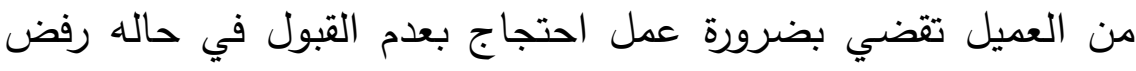
المسحوب عليه القبول، حيث ان رفض المسحوب عليه قبول الورقة

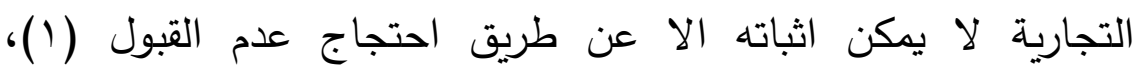

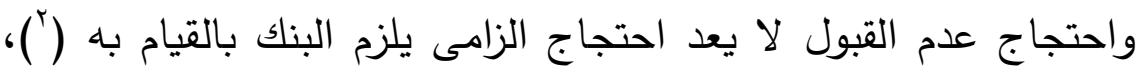

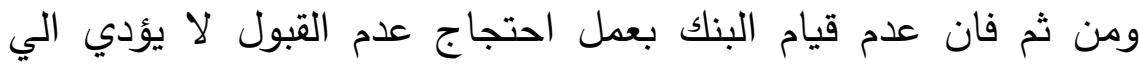

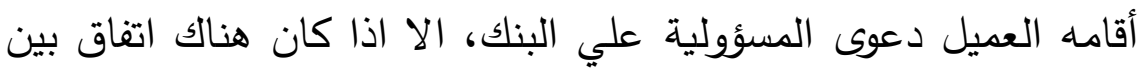

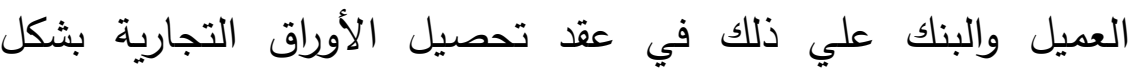

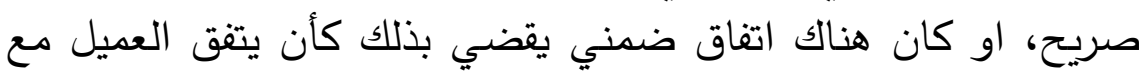

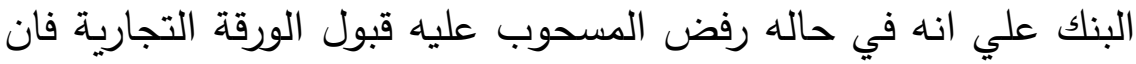
علي البنك إقامة الدعوى الصرفية علي الملتزمين صرفيًا دون الانتظار

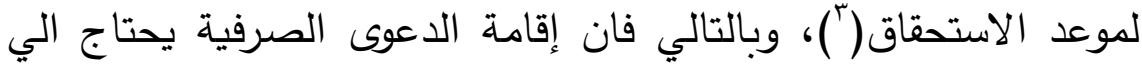

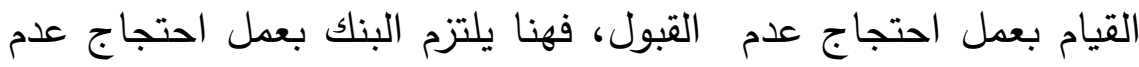

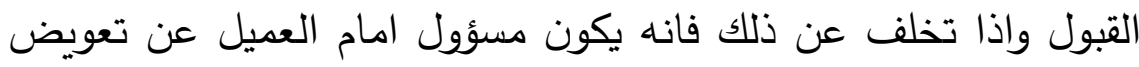

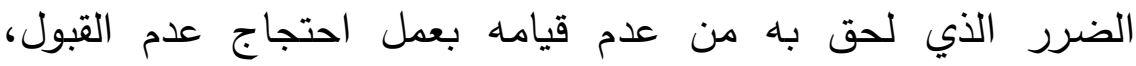

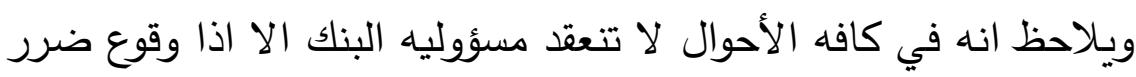

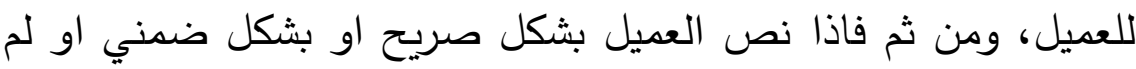

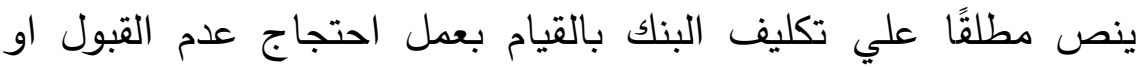
عدم عمله، فان مسؤوليه البنك لن تنعقد الا اذا وقع ضرر لبعل علي العميل

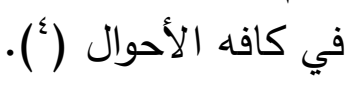

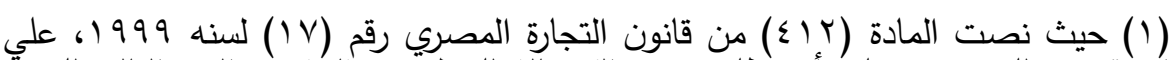

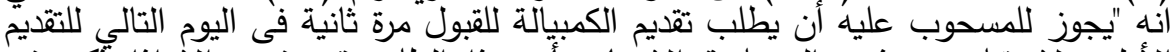

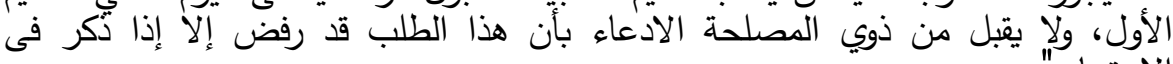

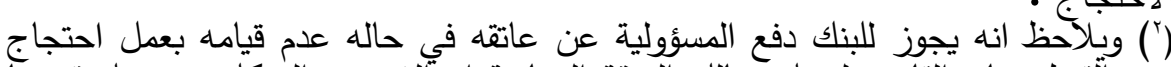

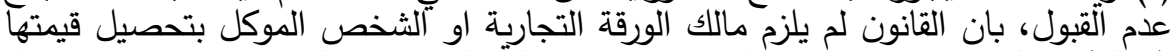

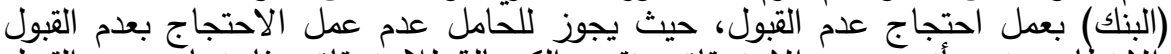

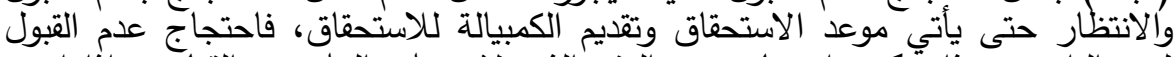

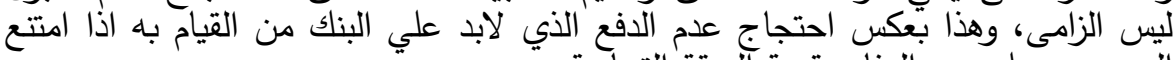

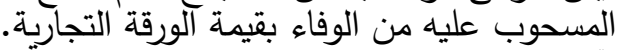

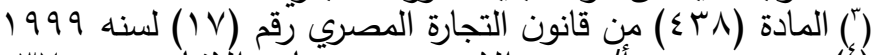

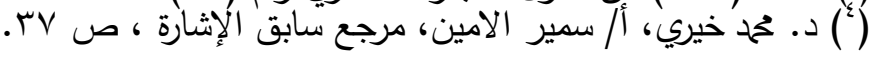


رابعًا: مسؤوليه البنك الناشئة عن خروجه عن نطاق عقد تحصيل

الأوراق التجاريـة.

البنك ملزم بتنفيذ عقد تحصيل الأوراق التجارية المبرم بينه وبين

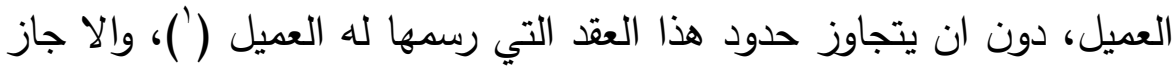
للعميل أقامه دعوى المسؤولية علي البنك اذا تجاوز تعليمات ذلتون ذلك العميل

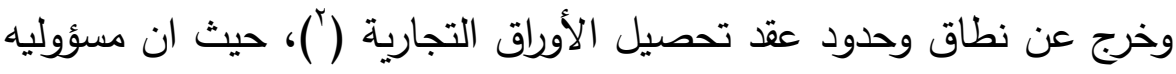

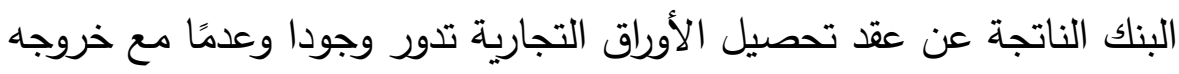

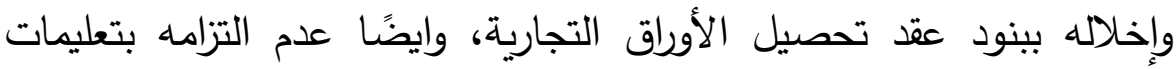

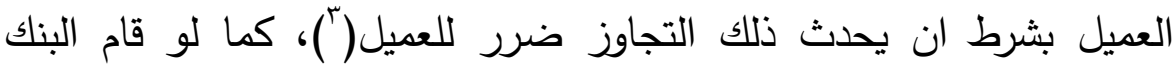

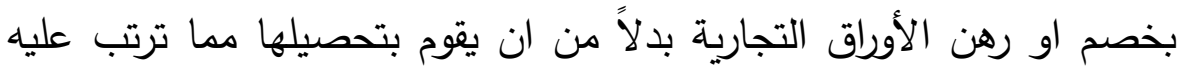

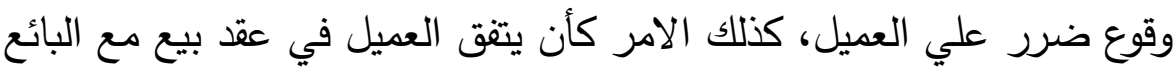

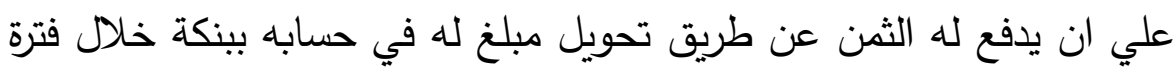

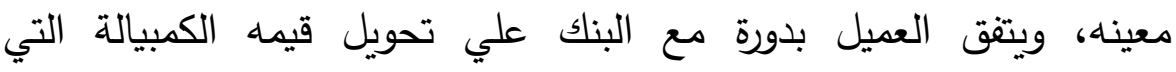
سيحصلها البنك بحساب البائع، ولكن البنك خالف تبعلف تعليمات العميل وقام

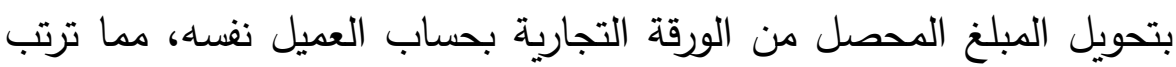
عليه فسخ البائع لعقد البيع الذي بينه وبين العميل لعدم دفع الثمن (أ). ولكن اذا خرج البنك عن نطاق عقد تحصيل الأوراق التجارية وخالف

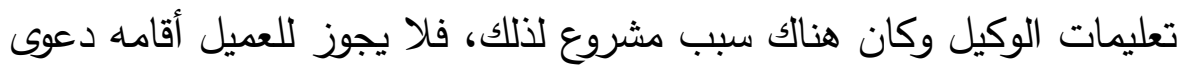

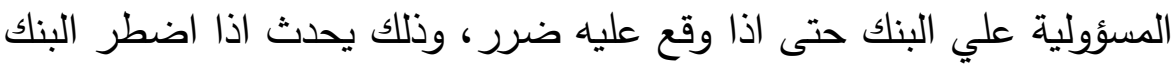

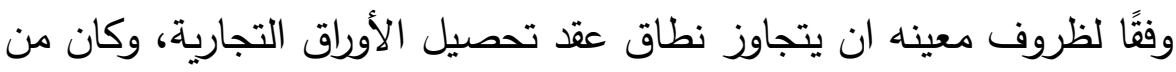

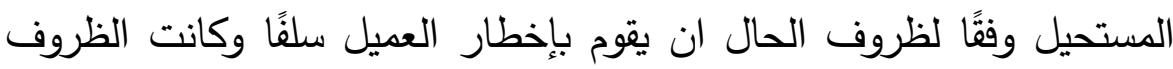

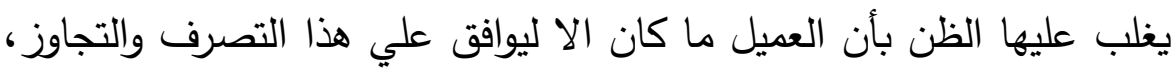

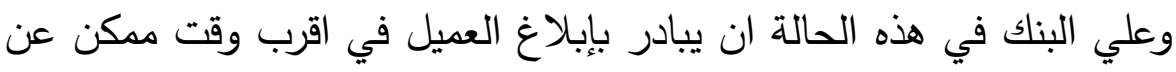

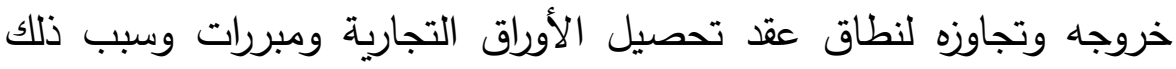

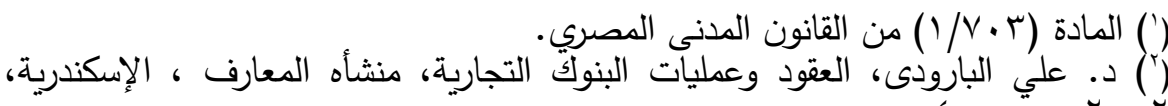

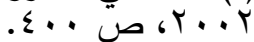

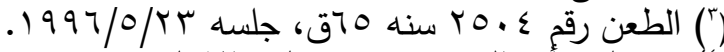

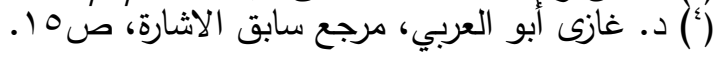


التجاوز (')، وكذلك يكون البنك مسؤول اذا تجاوز القواعد والأعراف المصرفية المنظمة لعمليات البنوك حتى وان لم يتم النص عليها في عقد تحصيل

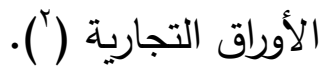

خامسًا: مسؤوليه البنك عن عدم اخطار العميل بالتطورات والوقائع

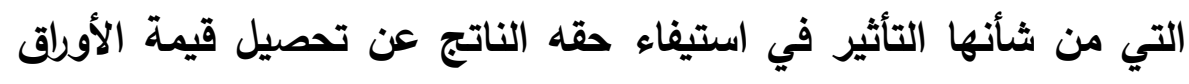
التجاربـة. لا يجوز للبنك ان ينقطع عن العميل اثناء تتفيذ عقد تحصيل الأوراق

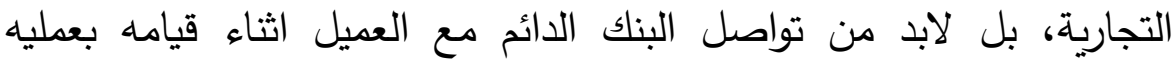

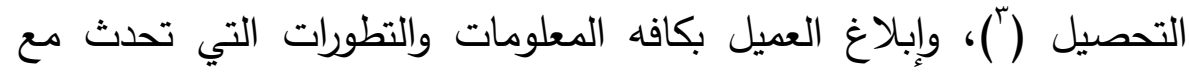

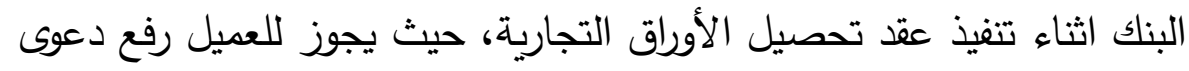

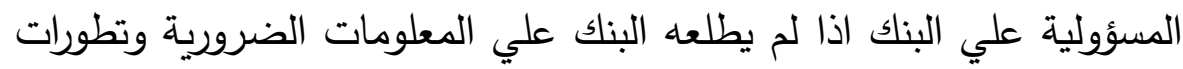

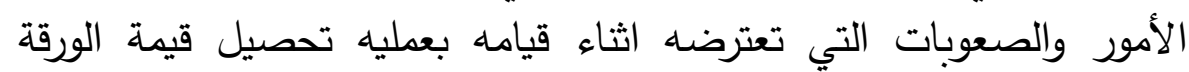

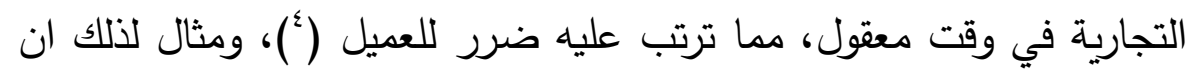

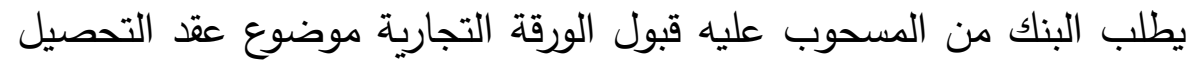

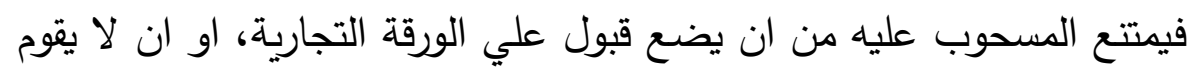
بالوفاء في موعد الاستحقاق بسبب افلاسه، ومن ثم لا لا يقوم البنك بإخطار العميل بتلك المعلومات والوقائع، مما ترتب عليه استمرار العميل في تعامله

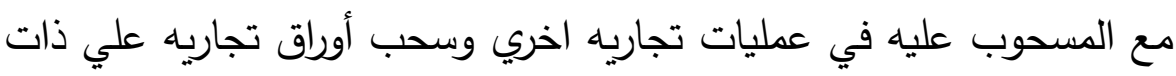

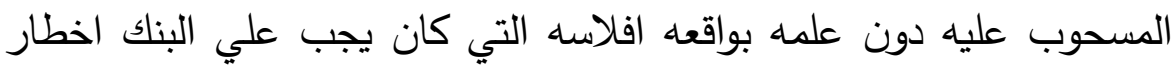

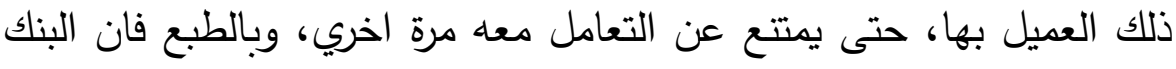
هنا يكون مسؤول عن تعويض الضرر الواقع علي العميل بسبب عدم اخطاره

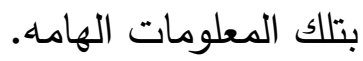

كذلك فان البنك يكون مسؤول اذا اخطر العميل بمعلومات خاطئة ،

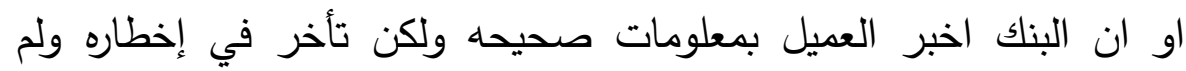

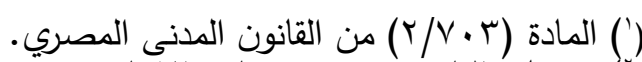

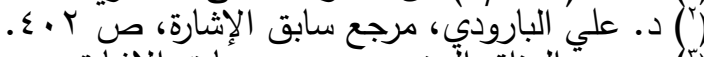

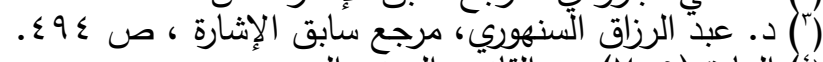

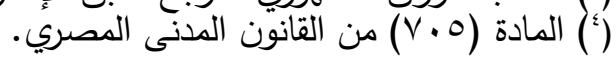


يخطر العميل فور وقوع الامر مما تسبب في وقوع ضرر علي العميل، كأن يقوم البنك بتحصيل قيمة الورقة التجارية ولا يخطر العميل فور حدو حدوث التحصيل والذي كان في حاجه ماسه لسداد ديون عليه من قيمه تلك الورقة التجارية المحصلة ولم يتمكن من سداد دينه في موعد استحقاقه مما ترتب في ماسه

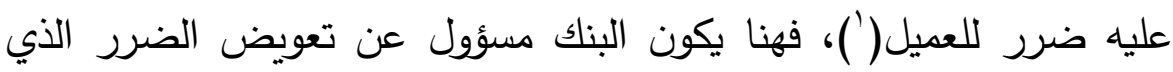

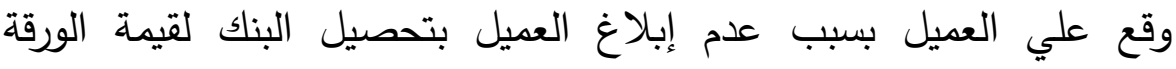
التجارية.

وبوجه عام يسأل البنك عن أي اضرار تقع علي العميل إذا تأخر

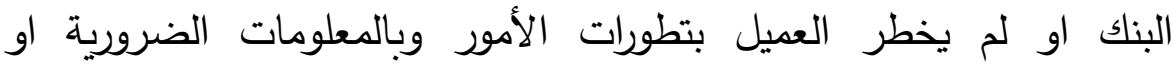
الصعوبات التي تعترضده، والتي لو علمها العميل لكان أقدم علي تغيير تعليماته للبنك حتى يتجنب وقوع ضرر عليه بسبب تنفيذ التعليمات السابقة علي حدوث تلك التطورات او الصعوبات ( )'.

سادسًا: مسؤوليه البنك عن عدم قبض مستحقات العميل في موعد

الاستحقاق.

يسأل البنك عن عدم قبض مستحقات العميل الناتجة عن الورقة

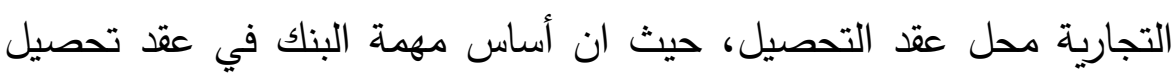

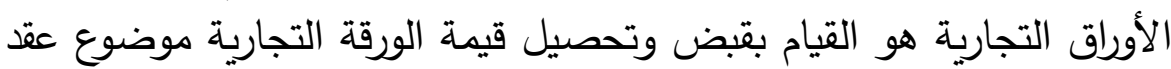
التحصيل، فاذا امتنع البنك تمامًا او أهمل في تحصيل وقيل قيمة الورقة التجارية

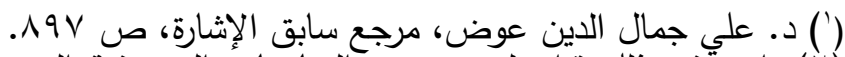

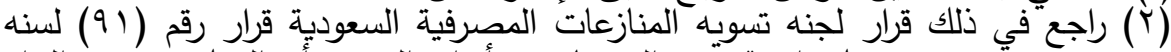

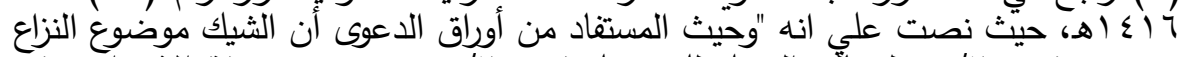

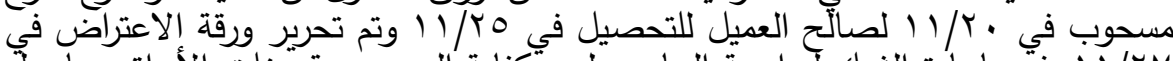

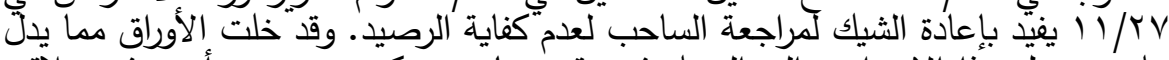

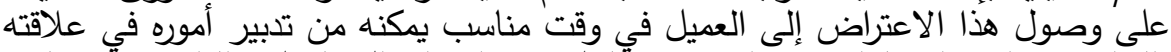

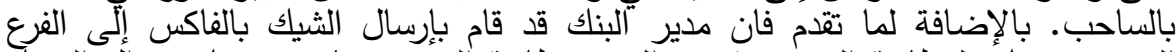

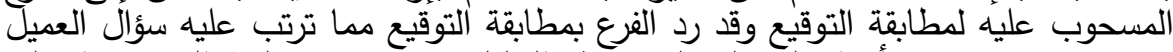

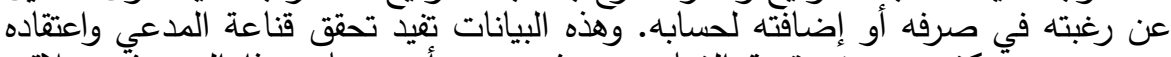

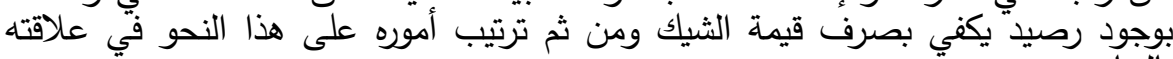
وحيث أنه يستفاد مما تقدم تقصير البنك في التحقق من كفاية الرصيد عند تقديم الشيك إليه

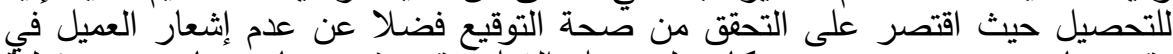

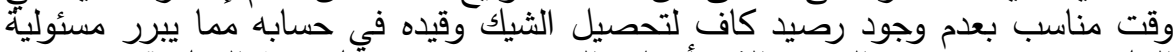
البنك بقدر تقصيره عن الضرد الذي أصاب الددعي بعدم تحصيل قيمة الثيك ". 
فيجوز للعميل أقامه دعوى المسؤولية عليه، ونستطيع ان نجمل حالات انعقاد مسؤوليه البنك عن عدم قبض مستحقات العميل في موعد الاستحقاق فيما

- -

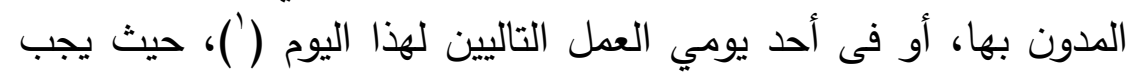
ان يحصل البنك الورقة التجارية في ذات التاريخ المدون بالورقة التجارية

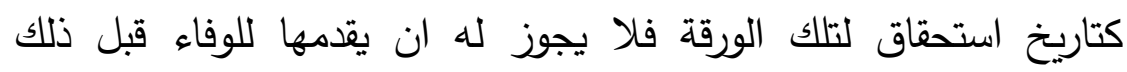

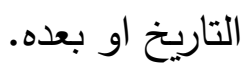

- كذلك فان مسؤوليه البنك تنعقد إذا امتنع عن قبول الوفاء الجزئي

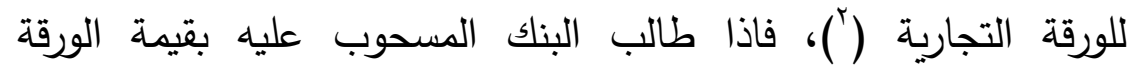
التجارية، ولكنه لم يجد لدي المسحوب عليه كامل المبلغ بل وجد معه جزء لبه من مبلغ الورقة التجارية، فان علي البنك ان يتسلم من المسحوب لان عليه

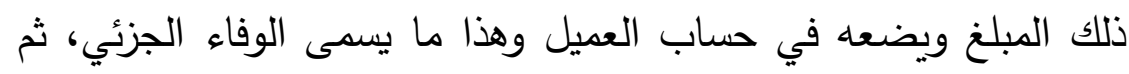

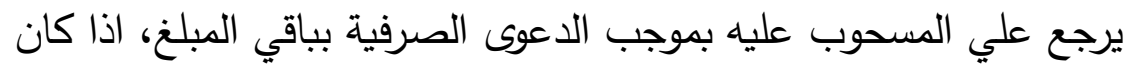

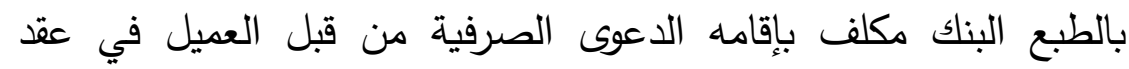

$$
\text { تحصيل الأوراق التجارية ("). }
$$

-

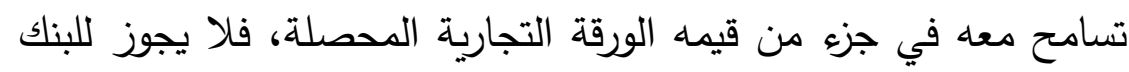

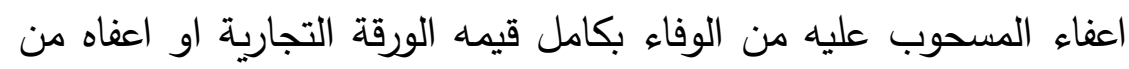

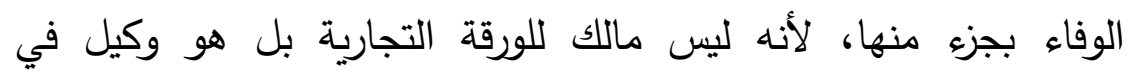
تحصيل قيمتها فقط.

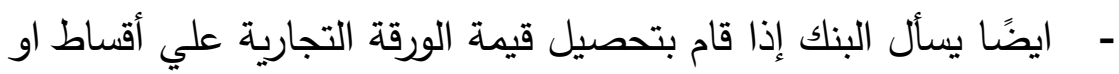

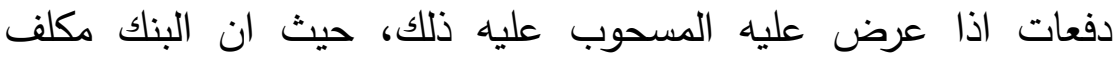

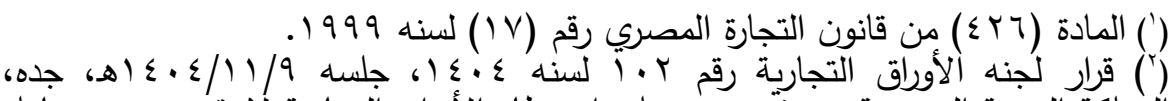

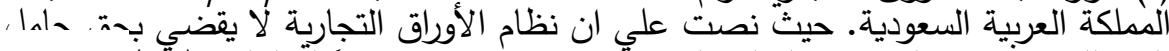

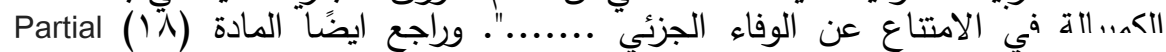
"Payment بالقواعد الموحدة للتحصيل. التشويل.

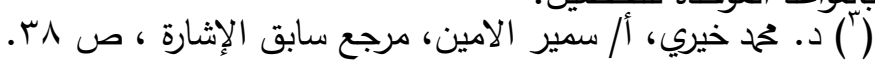


بتحصيل قيمة الورقة التجارية كامله ودفعه واحده، فلا يجوز له تقسيط المبلغ او تجزئته ('). - - كما ان البنك يسأل في حاله ان يقوم بتحصيل قيمة الورقة التجارية

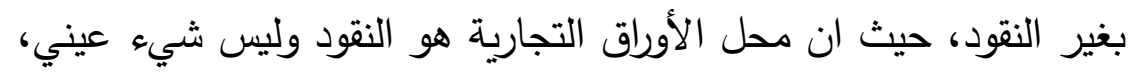

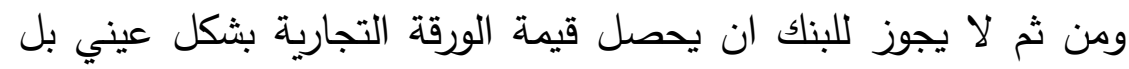

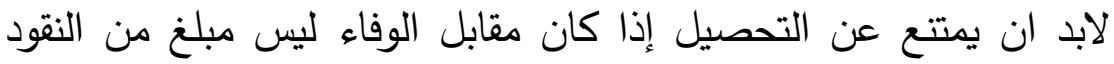

- - كذلك يسأل البنك إذا قام بتحصيل قيمة الورقة التجارية بعمله اخري

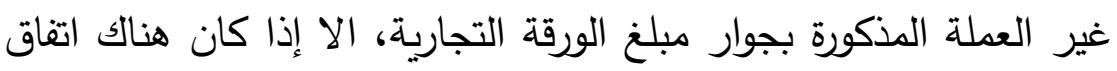
بينه وبين العميل علي ذلك، او إذا أخطر العميل بذلك ووافق العميل (ب).

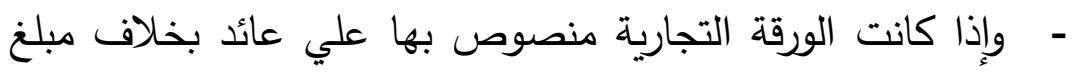
الورقة التجارية ذاته، فان البنك يكون مسؤول عن تحصيل ذلك ذانك العائد

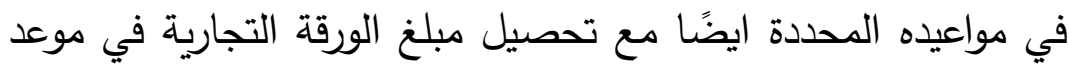

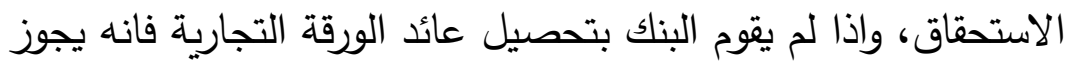

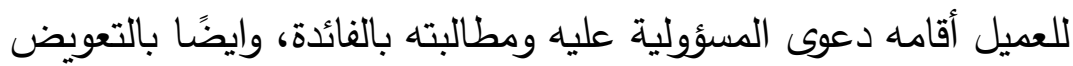
اذا وقع عليه ضرر من ذلك (ع).

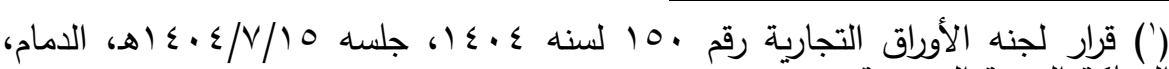

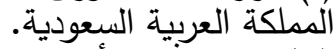

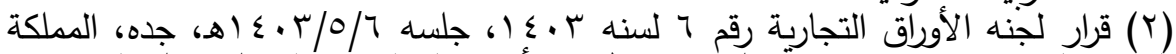

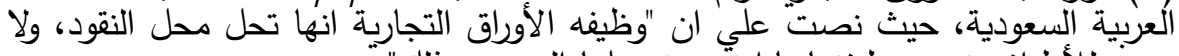

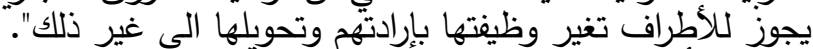

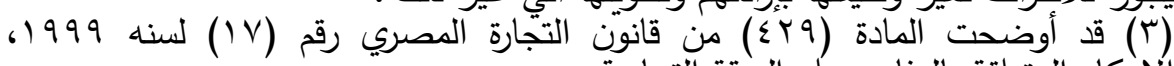

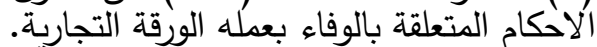

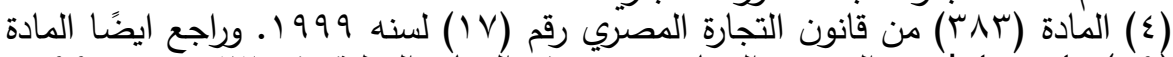

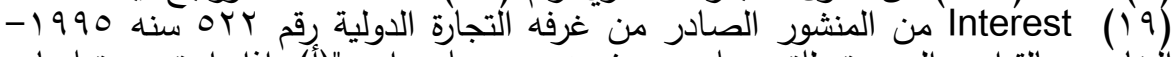

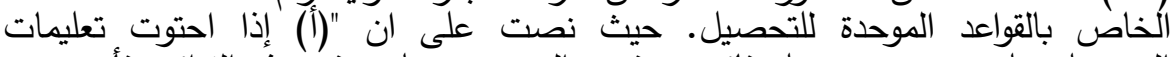

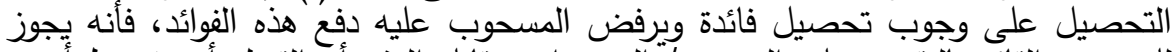

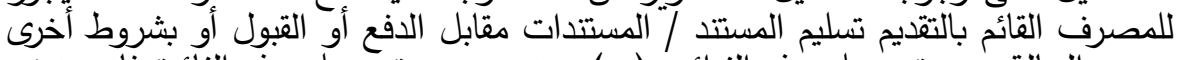

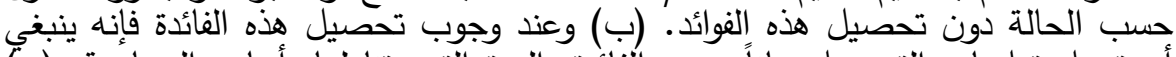
أن تحمل تعليمات التحصيل بياناً بسعر الفائدة والمدة التي يتناولها وأساس المحاسبة.

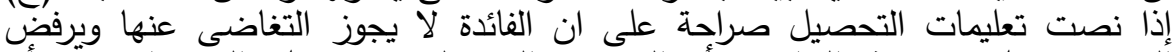

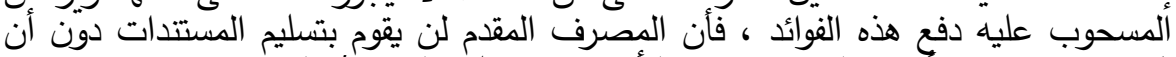

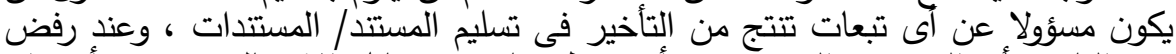

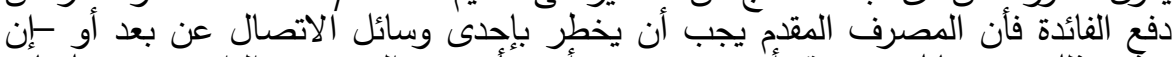

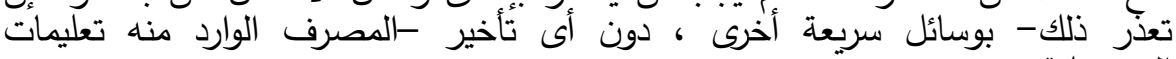

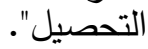


- - كما تعقد دعوى مسؤوليه البنك إذا كان المدين او المسحوب عليه

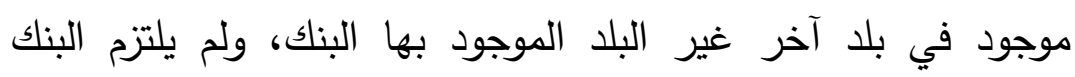

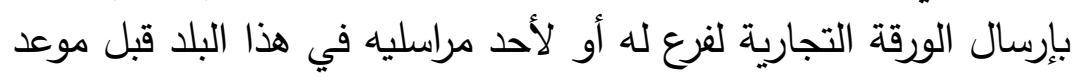

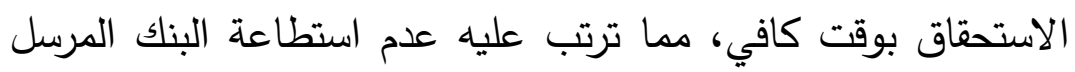
اليه الورقة التجارية من تحصيل قيمتها في موعد استحقاقها. سابعًا: مسؤوليه البنك عن اخلاله بإفثاء اسرار العميل المتعلقة بعقد تحصيل الأوراق التجارية (').

تنعقد مسؤوليه البنك إذا قام بإفثاء اسرار العميل الواردة بعقد تحصيل

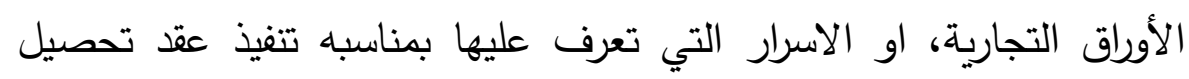

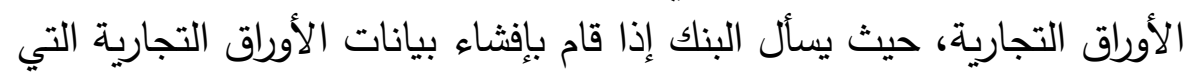

يقوم بتحصيلها لدائنى العميل او للغير (').

ثامنًا: مسؤوليه البنك عن عدم صحة بيانات الورقة التجارية

المكلف بتحصيلها.

يجب علي البنك عند تسلمه الورقة التجارية من مالكها بعد ابرام

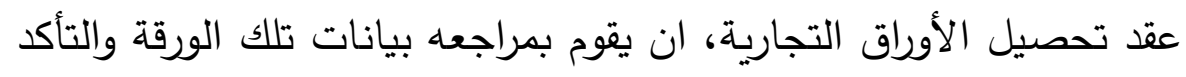

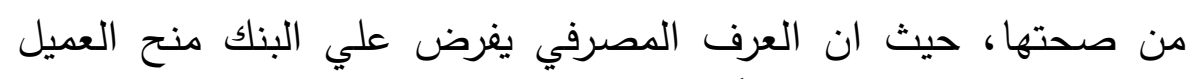

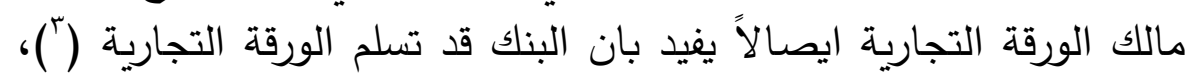
مما يعنى ويقيم معه الدليل علي ان البنك قد قام بفحص الورقة التجارية

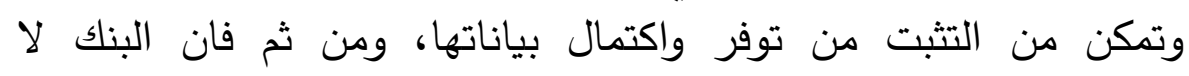
يستطيع نفي مسؤوليته عن عدم استطاعته القيام بتحصيل قيمة الورقة

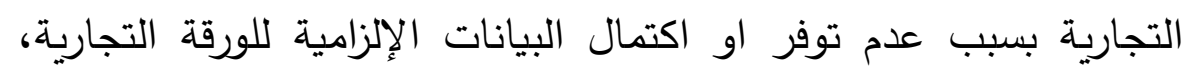

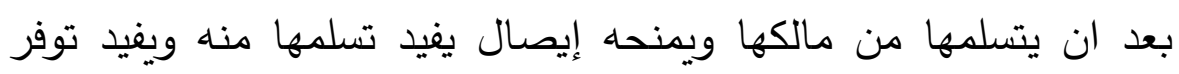

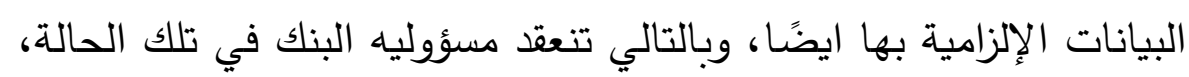

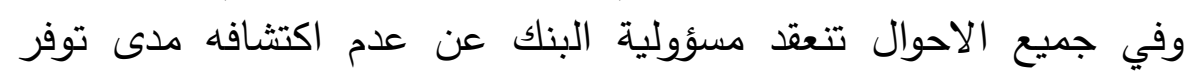

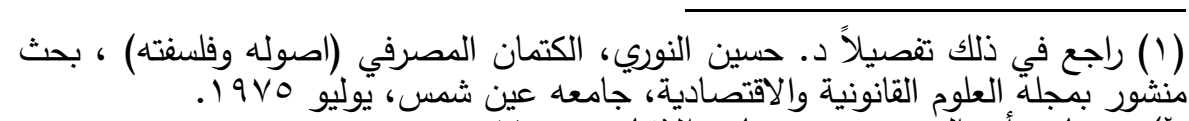

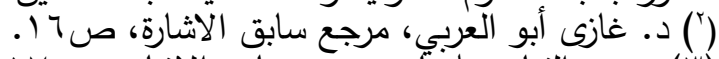

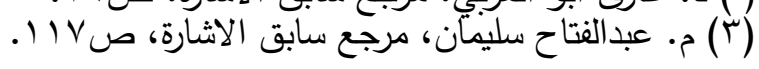


البيانات الإلزامية من عدمه بوصفه مهنيًا محترفًا (1).

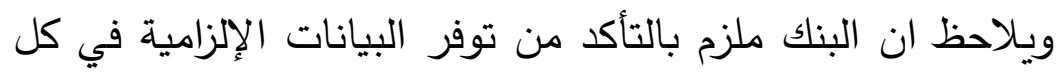

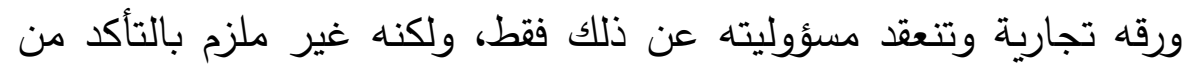

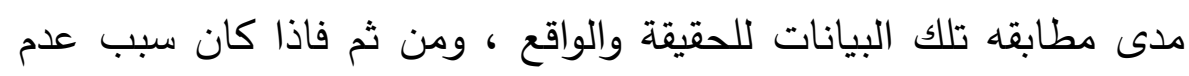

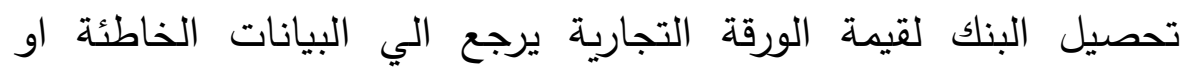

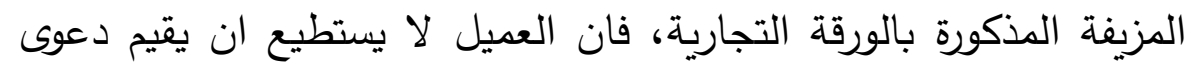

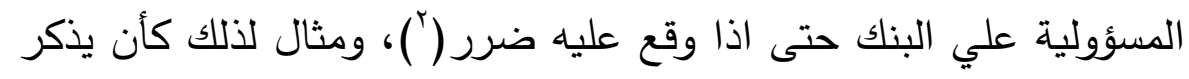

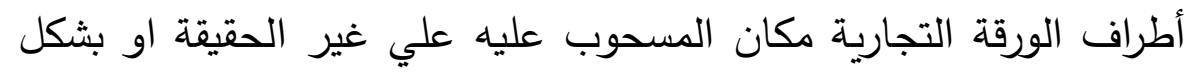

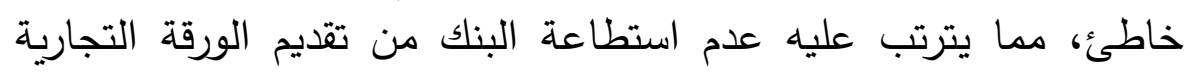

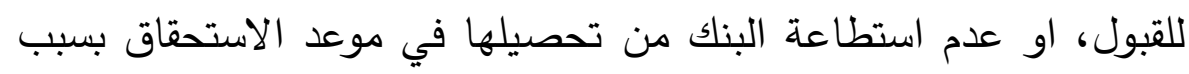

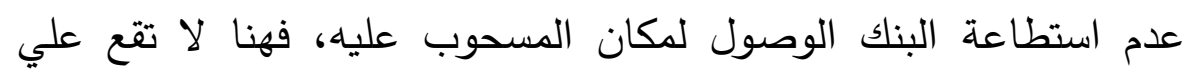

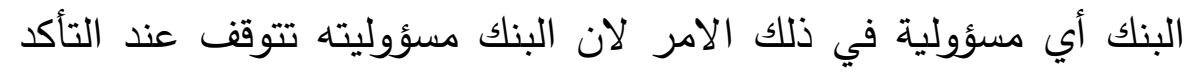

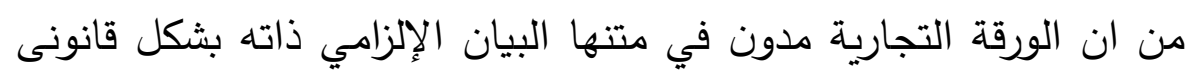

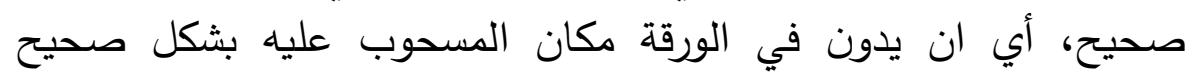

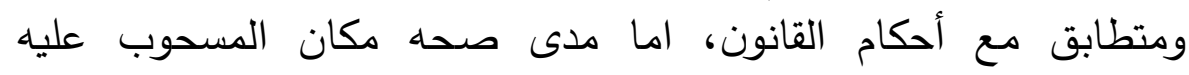

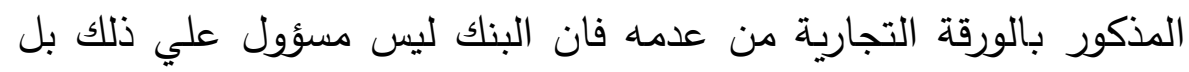

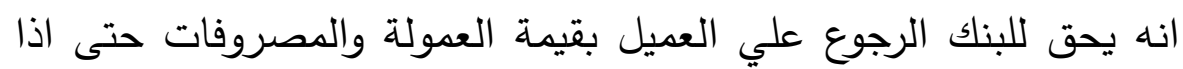

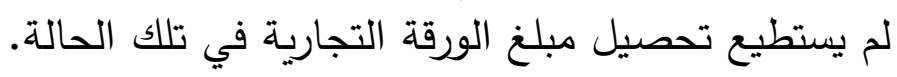

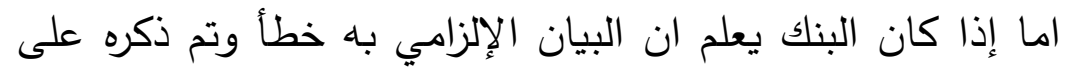

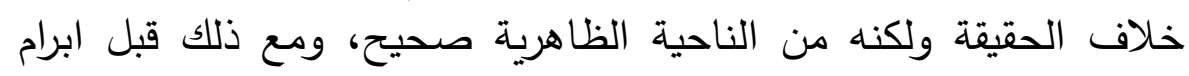

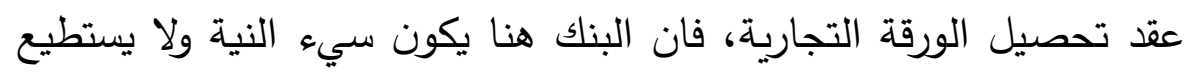

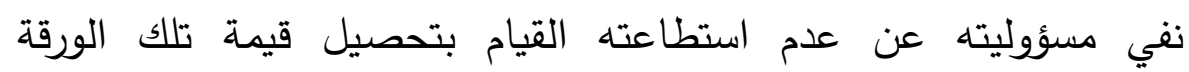

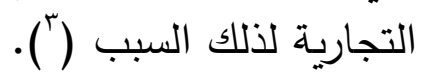

(1) وقد تطلب القانون مجموعه من البيانات الإلزامية التي يجب توافرها في كل ورقاته

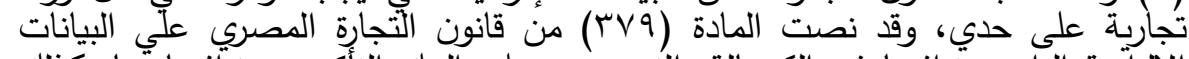

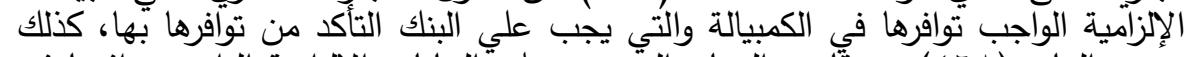

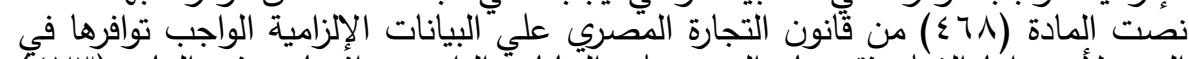

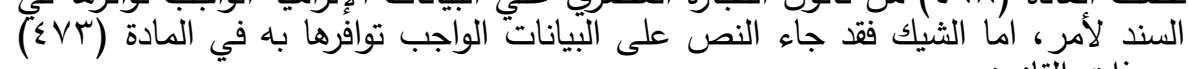

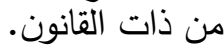

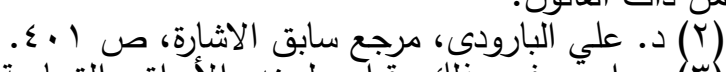

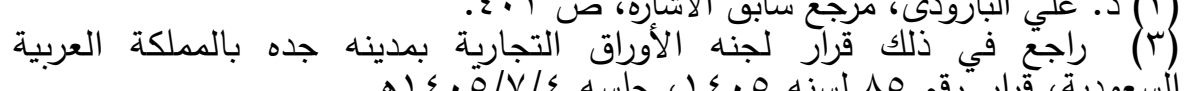

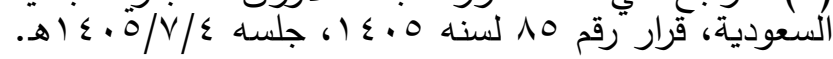




\section{تاسعًا: مسؤوليه البنك عن عدم صحة تظهير الورق التجارية}

المكلف بتحصيلها (').

تنعقد مسؤوليه البنك فيما يتعلق بتظهير الورق التجارية الواجب التبان

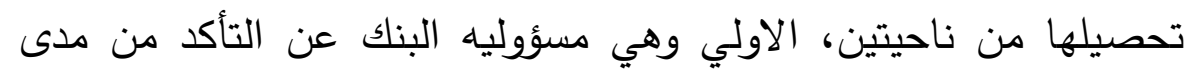

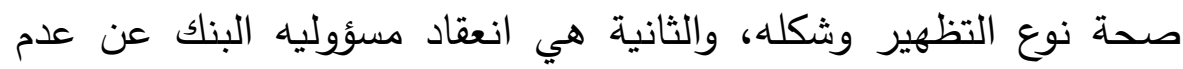

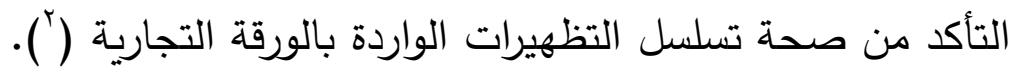
كما سبق الذكر فان التظهير الذي يؤدى الي قيام البنك بتحصيل التئيل

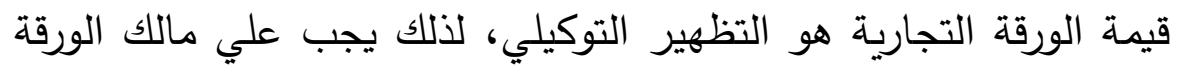

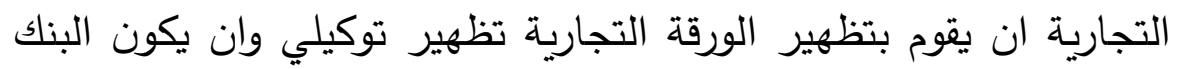
المنوط بالقيام بعملية التحصيل هو المظهر الئهر اليها ومن ثم يجب ان يتأكد البنك من نوع التظهير التهيل الموجود بالورقة

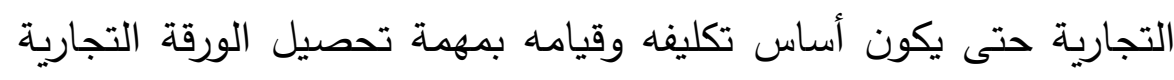

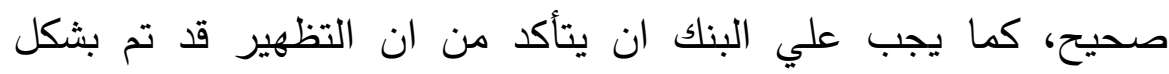

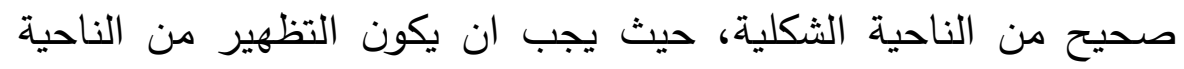
الثكلية مكتوب وتكون كتابه التظهير علي الورقة التجارية ذاتها، ولان التانية

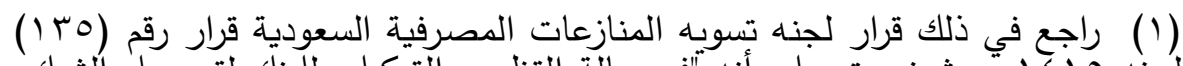

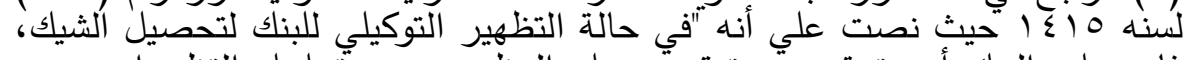

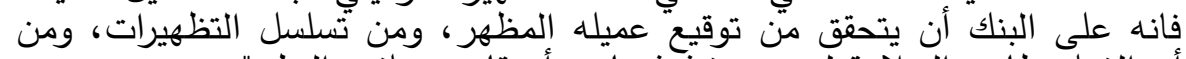

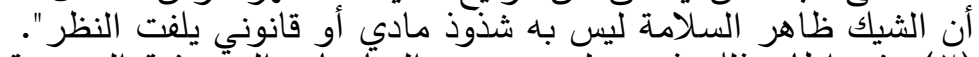

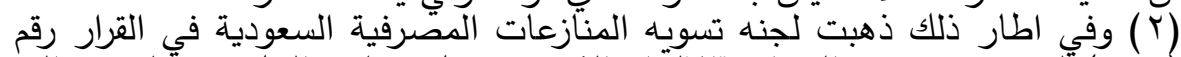

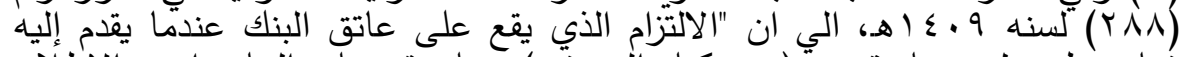

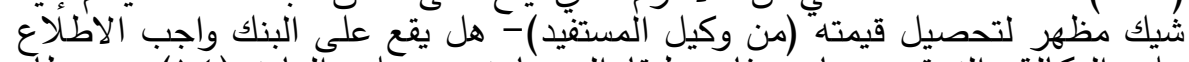

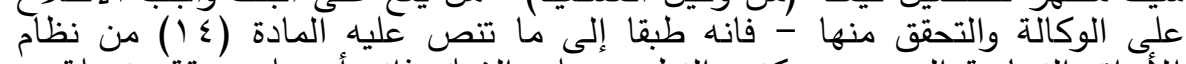

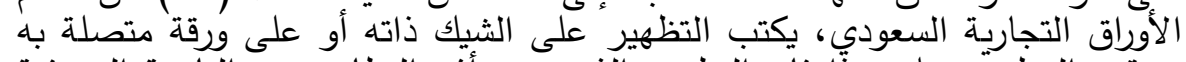

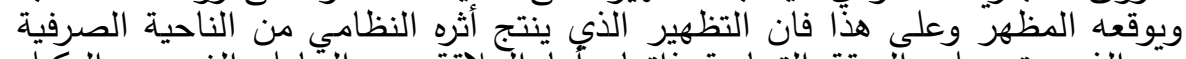

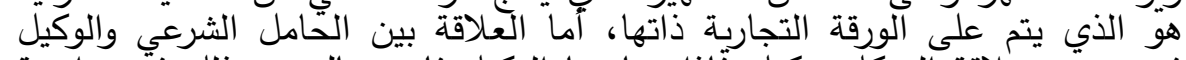

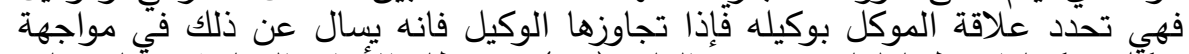

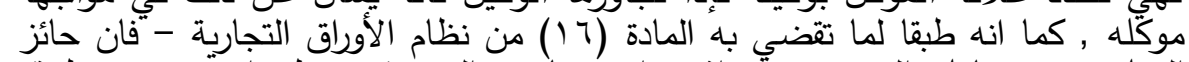

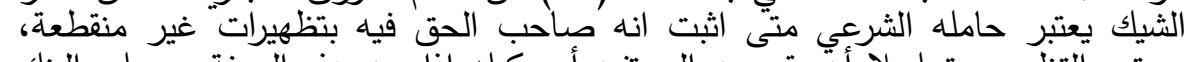

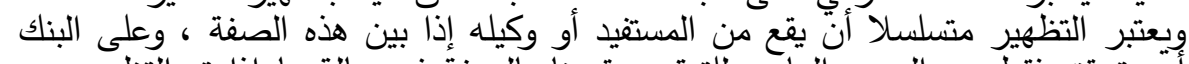

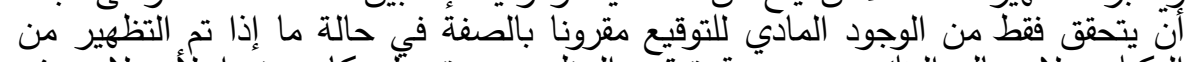

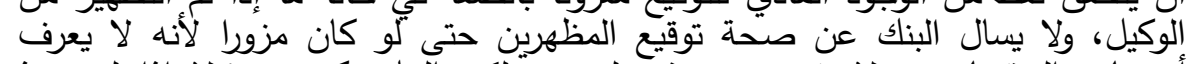

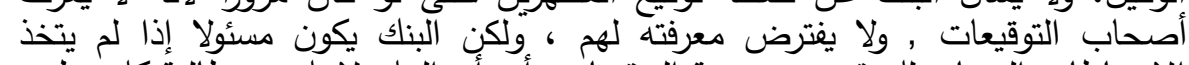

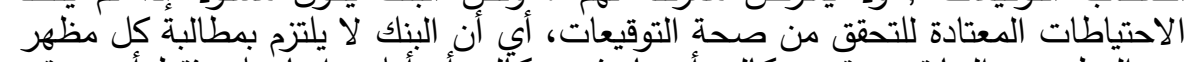

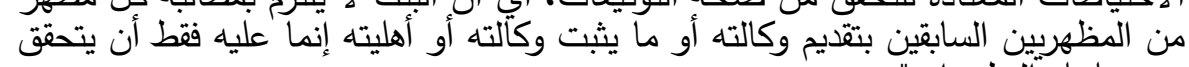

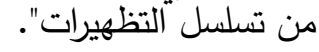




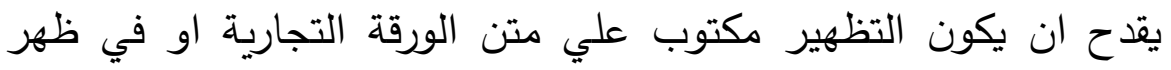

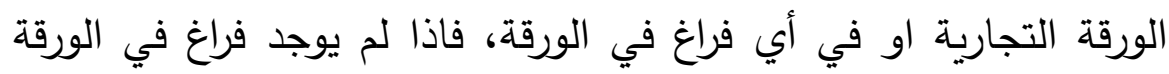
التجارية ذاتها فيجوز كتابه التظهير علي ورقه أخرى متصلية فيلة بالورقة

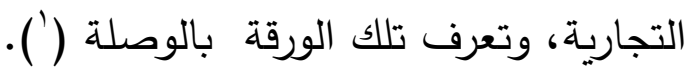

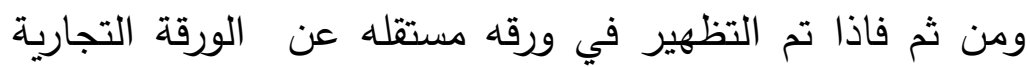
فانه لا يعد تظهير صحيح من الناحية القانونية ويفقد اثرة لمخالفته لمبدأ الكفاية الذاتية للورقة التجارية، كذلك يجب لطان علي البنك التأكد من صحه

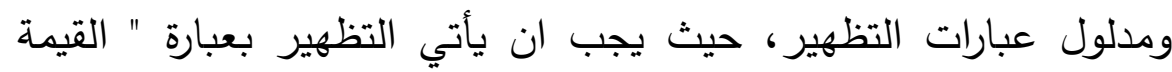

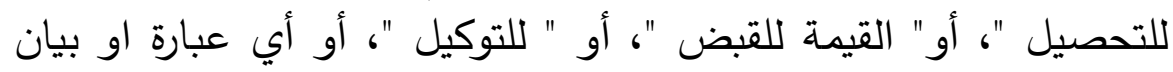
آخر يفيد توكيل حامل الورقة التجارية او العميل للبنك في تحصيل

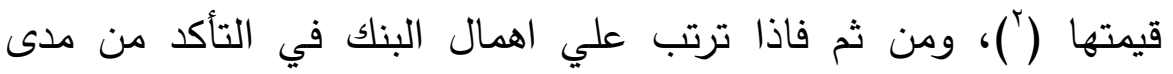

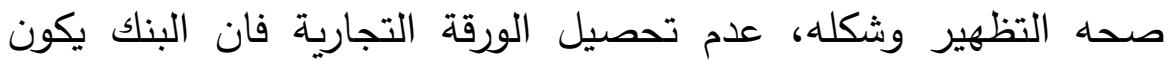

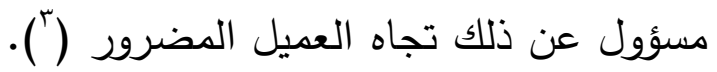
عاشرا: مسؤوليه البنك عن التأكد من صفه مظهر الورة الوقة التجارية

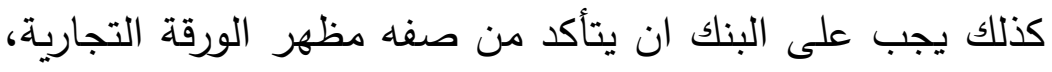

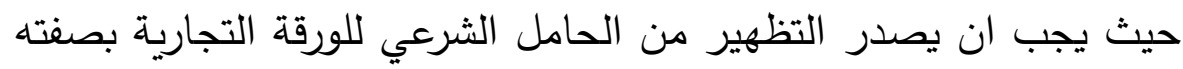

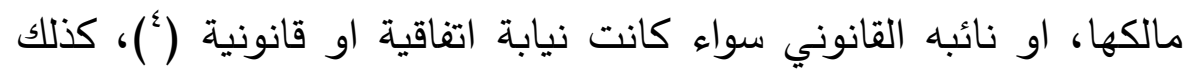
يجب على البنك ان يقوم بفحص تسلسل التظهيرات الموجودة بالورقة

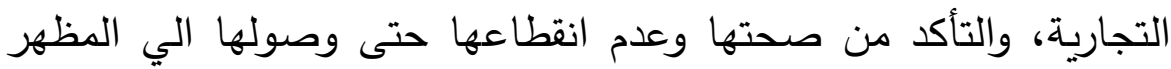
الحالي، والا كان البنك مسؤول إذا كان عدم تحصيل الورقة التجارية

(1) Ripert, Georges, Roblot, René, Traité de droit commercial [Texte imprimé]. $2 . \quad$ Valeurs mobilières, effets de commerce, opérations de banque et debourse, contrats commerciaux, procédures collectives de redressement et de liquidation,Paris, 1976. P. 132.

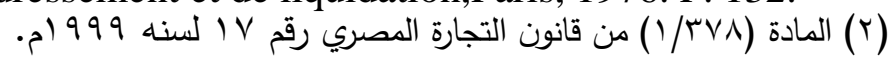

3)( Ripert, Georges, Roblot, René, Op. Cit. p136.

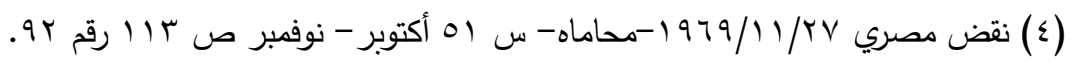




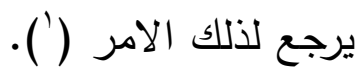 \\ الإلاب الثاني \\ نطاق مسوفوليه البناك بعد تصميل قيمة الأوداق التبارية}

تناولنا فيما سبق مسؤوليه البنك من بداية تسلمه الورقة التجارية

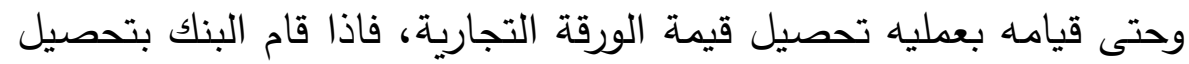
قيمه الورقة التجارية او لم يقم بتحصية تحيلها، فانه يظل ملتزم بالقيام

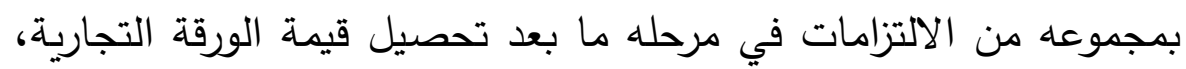

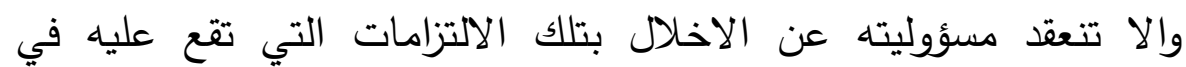

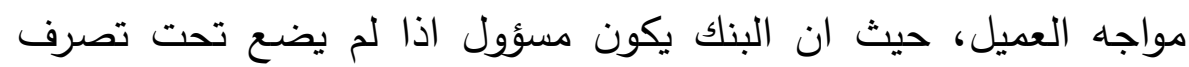

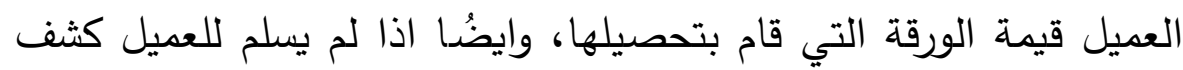

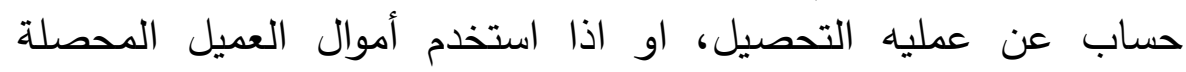

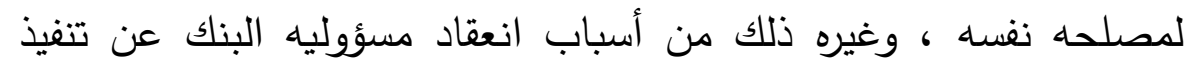
عقد تحصيل الأوراق التجارية بعد قيامه بعمليه التحصيل، وسوف ذبه نقوم

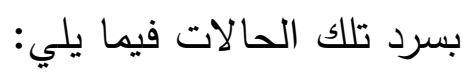

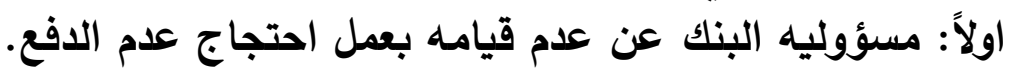

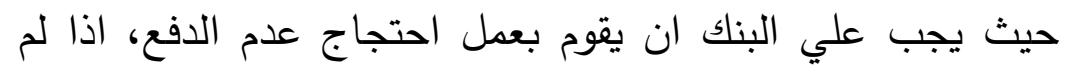

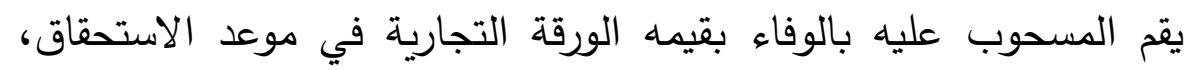
كما يجب ان يلتزم البنك بعمل الاحتجاج في المواعيد النظامية المقررة

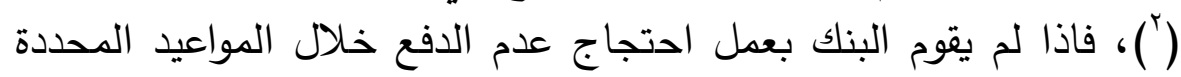
مما ترتب عليه ضياع حق العميل في الرجوع الصرفي علي الملتزمين

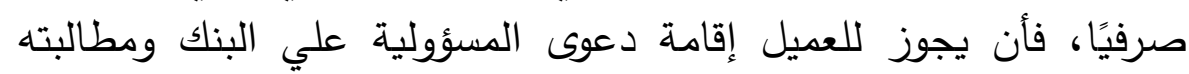
بالتعويض اذا وقع عليه ضرر من ذلك، ويلاحظ انه قد ينص العميل في

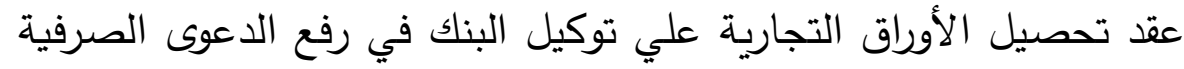

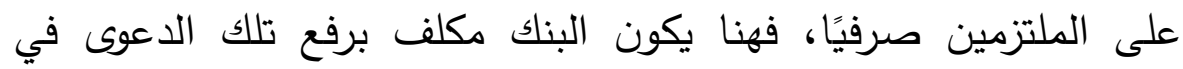

(1)

L'ENCAISSEMENT

\section{TOE} CHEQUES ET EFFETS DE COMMERCE [Microforme, 1989. P.243.

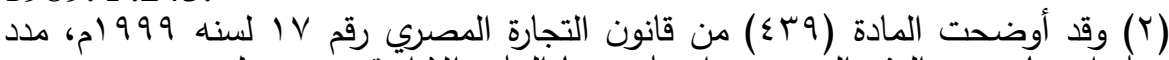
عمل احتجاج عدم الدفع التي يجب انس يلتزم بها البنك وارة الان انعقدت مسؤوليته. 
مواعيدها المحددة قانونًا، والا انعقدت مسؤوليه عن ذلك ايضًا، اما اذا لم

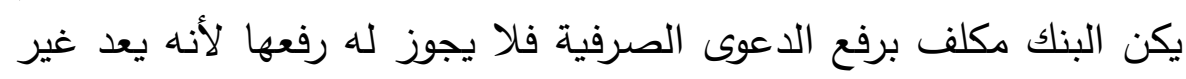
صاحب صفه في أقامه تلك الدعوى (').

ثانيًا: مسؤوليه البنك عن عله عدم إعادة المبلغ المحصل للعميل.

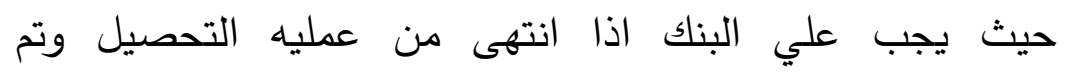

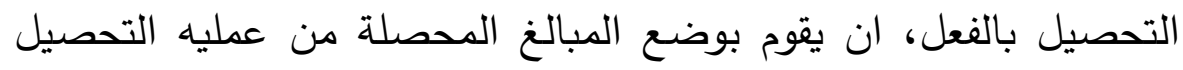

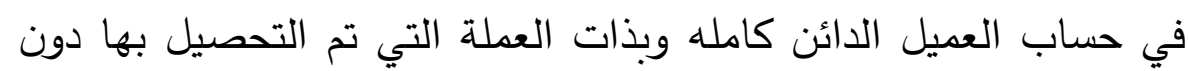
تأخير في ذلك (')، كما عليه ان يبلغ العميل كما سبق الذكر بالانتهاء

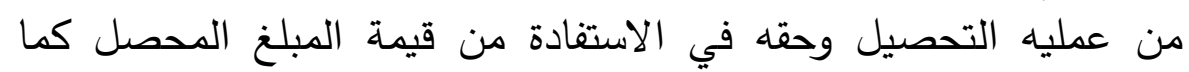

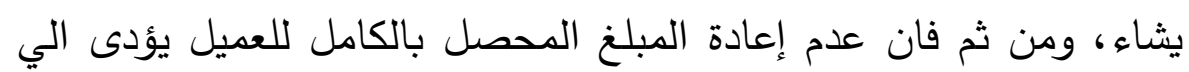
رفع دعوى المسؤولية علي البنك نتيجة لذلك (r) إن.

ثالثًا: مسؤوليه البنك إذا قام باستخدام أموال العميل المحصلة

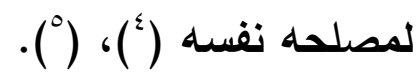

كذلك تنعقد مسؤوليه البنك إذا ثبت انه قام باستغلال المبالغ التي

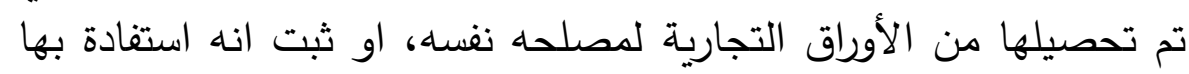

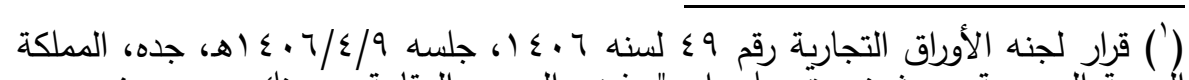

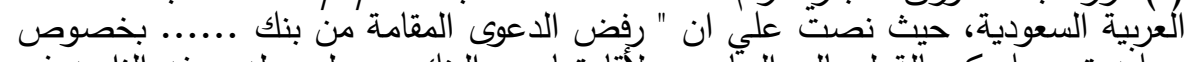

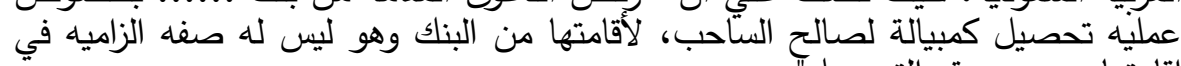

2) (ESSAM EL KALYOUBI, Op. Cit. p 255.

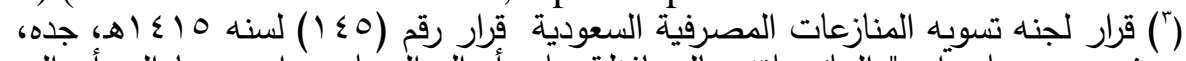

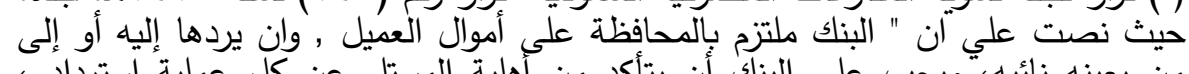

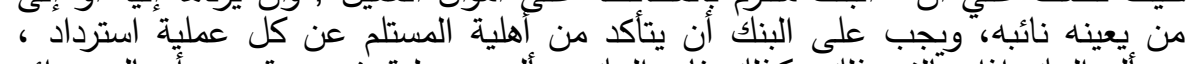

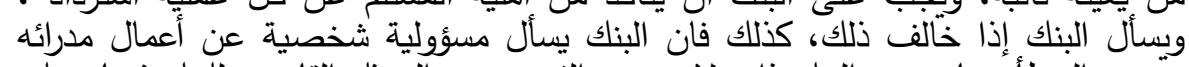

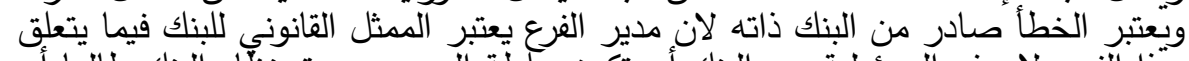

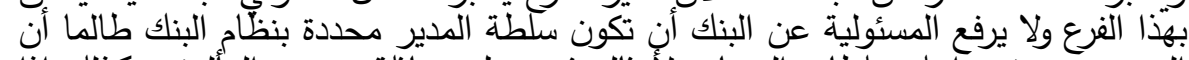

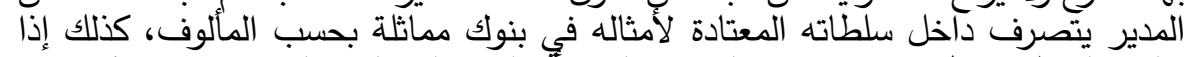

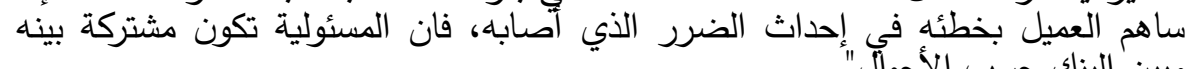

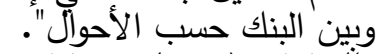

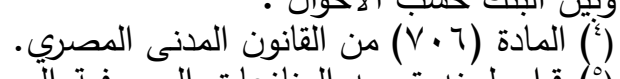

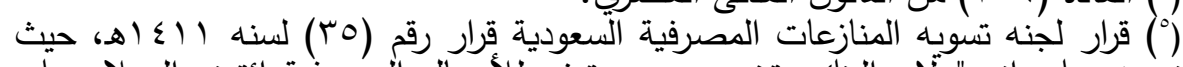

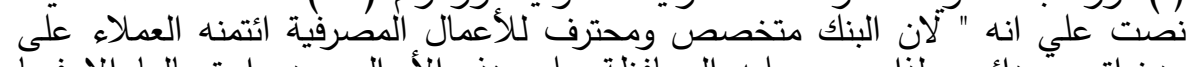

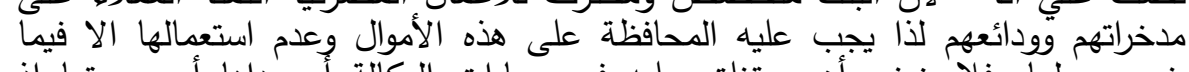

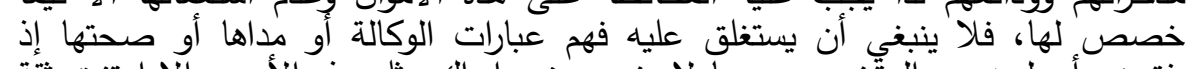

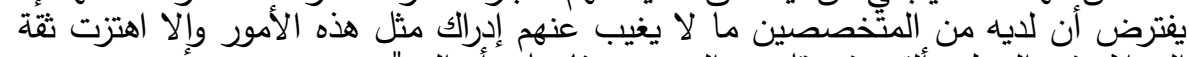

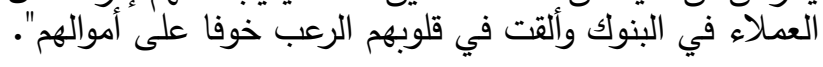


باي شكل من الاشكال، كما لو قام البنك بإقراض تلك المبالغ لاحد

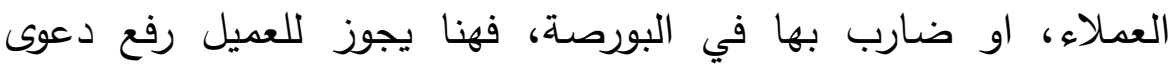

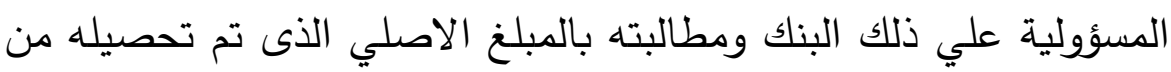

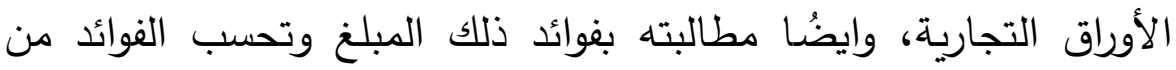

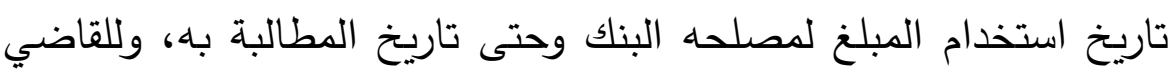
سلطة تحديد مقدار الفائدة ('). رابعًا: مسؤوليه البنك عن عدم تقدئ الديم كشف حساب للعميل عن عمليه تحصيل الورقة التجارية.

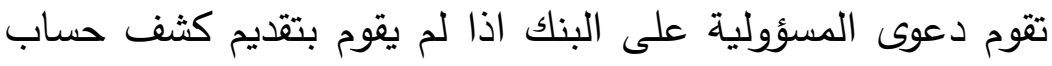
للعميل بعد الانتهاء من عمليه التحصيل، حيث يجب انب ان يقدم البنك

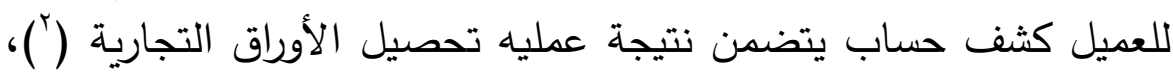

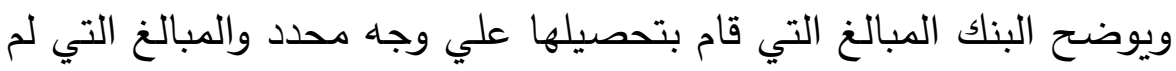

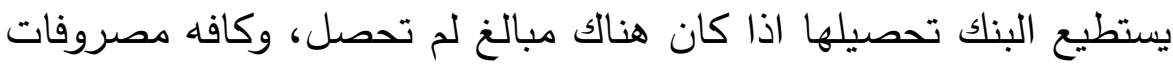

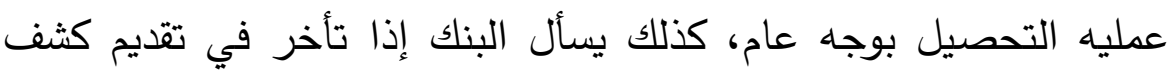

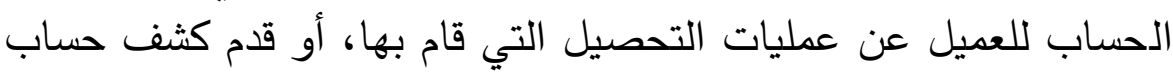
غير حقيقي للعميل وأصيب العميل بضرر بسبب ذلك ، كذلك يسأل البنك عن عدم رد أي مبالغ قد حصل عليها بسبب تنفيذ عقد تحصيل الأوراق

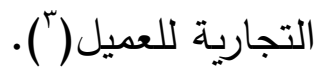
غير ان هناك حالات يعفي فيها البنك من تقديم كثف الحساب

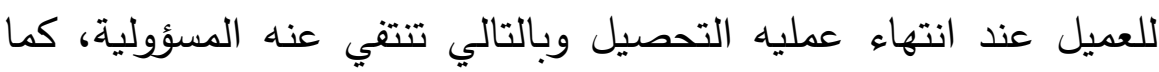
لو كان هناك اتفاق بين البنك والعميل في عقد تحصيل الأوراق التجارية

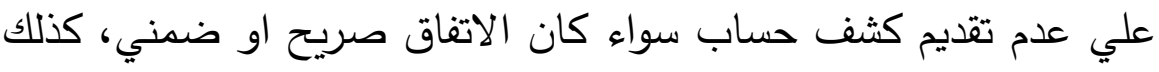
يعفي البنك من تقديم كثف حساب اذا كان تقديم كثف كثف الحساب التفاب

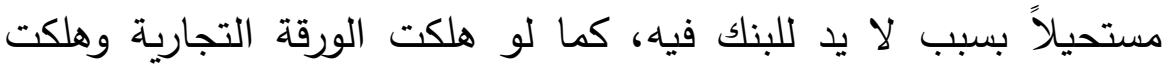

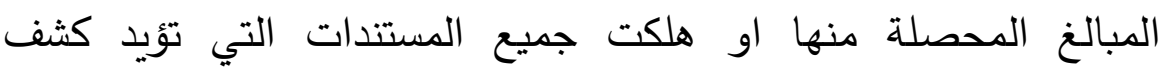
الحساب، كذلك يعفي البنك من تقديم كثف حساب عن عمليه تحصيل

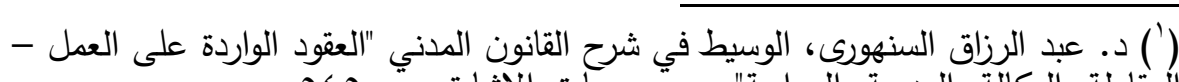

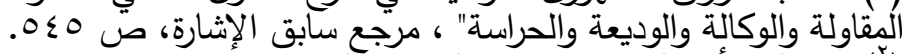
3) (ESSAM EL KALYOUBI,Op. Cit. p 257.

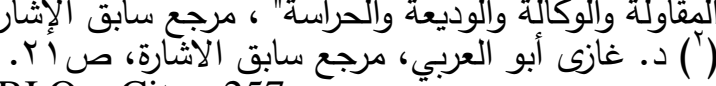


الأوراق التجارية اذا كان قد قدم جميع المستندات للعميل مسبقًا قبل انتهاء عمليه التحصيل ('). خامسًا: مسؤوليه البنك عن عدم رد الأوراق التجارية المحصلة

للعميل بعد تحصيلها.

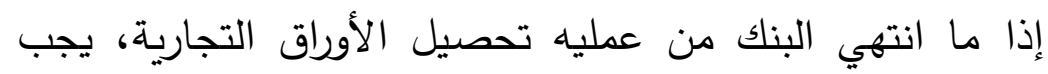
عليه ان يرد الورقة التجارية الي العميل سواء قام البنك بتحصيل قيمة التورية

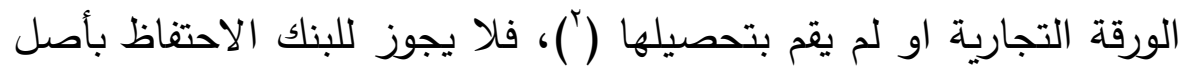

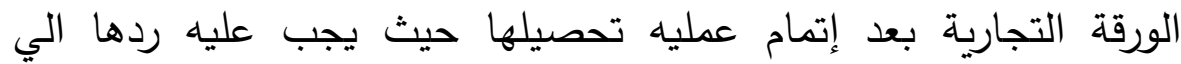

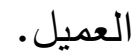

كذلك إذا لم يقم البنك بتحصيل الورقة التجارية لأي سبب من الأسباب فان عليه تبصير العميل بذلك، كما عليه رد تلك الورقة للعميل علي الفور حتى يتمكن العميل من اتخاذ ما يلزم من إجراءات من اجل

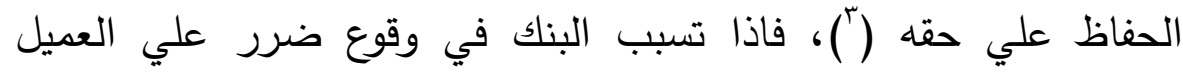

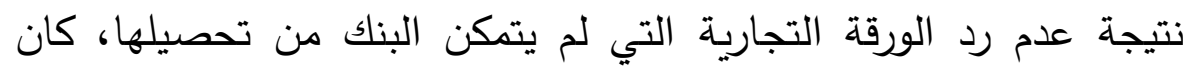

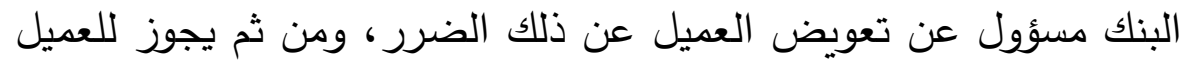

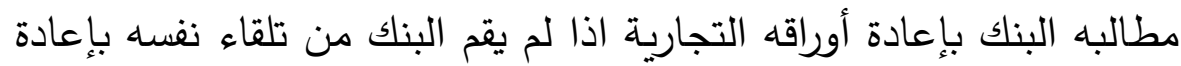
تلك الأوراق، والا يجوز للعميل مطالبة البنك بها بالدها ورفع دعوى المسؤولية

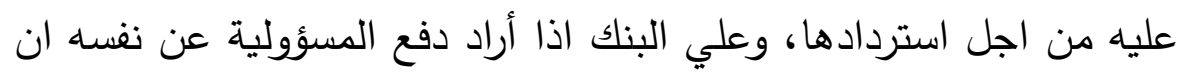

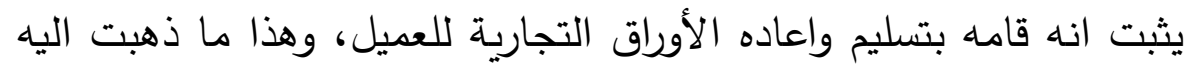

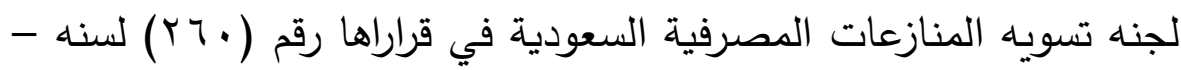

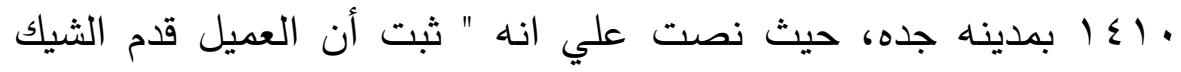

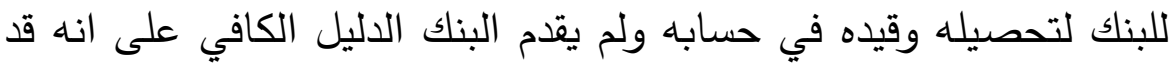
أعاد الشيك للعميل، ذلك أن قصاصة الورق التي قدمها البنك على نحو لكابل

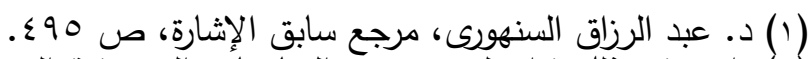

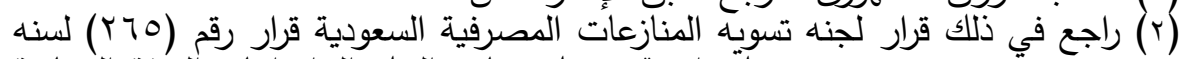

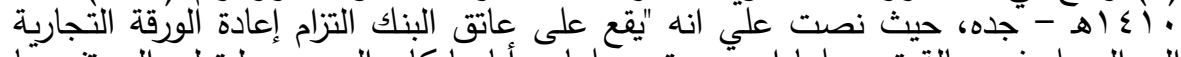

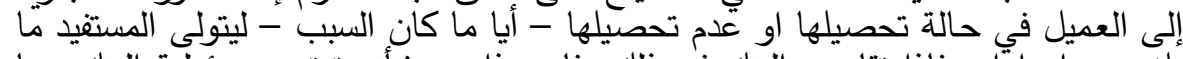

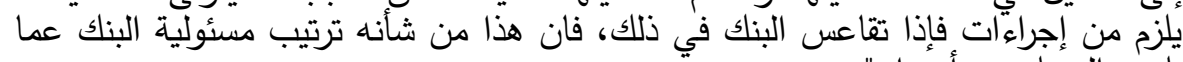
3)( Ripert, Georges, Roblot, René, Op. Cit. p158. 
ما سبق وصفه لا ترقى إلى مستوى الدليل الذي تطمئن إليه قناعة اللجنة

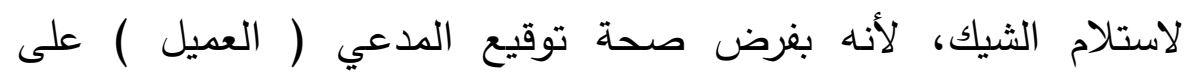

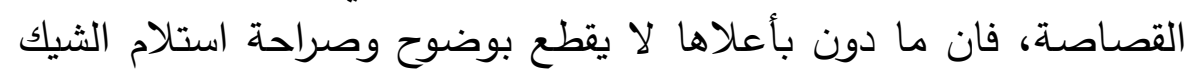

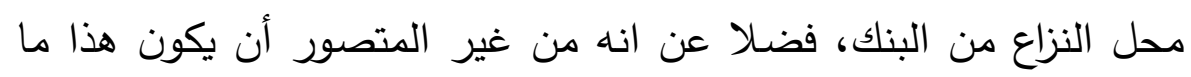

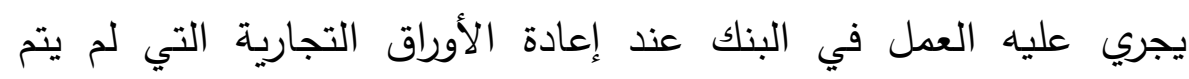

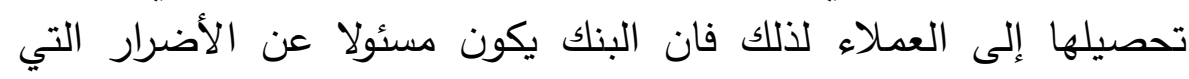
لحقت بالمدعي بسبب عدم تحصيل مبلغ الشيك ولا يؤثر في ذلك ما ذكره

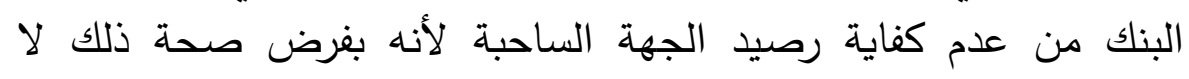

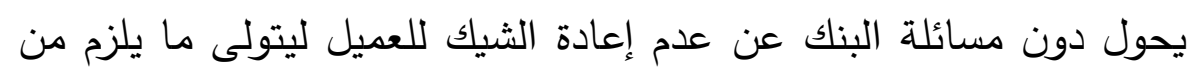

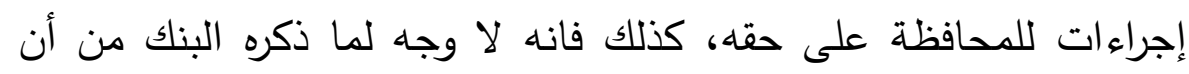

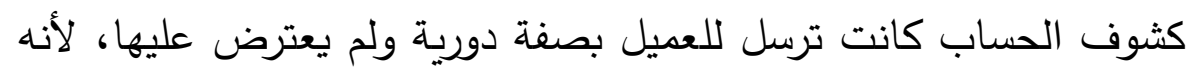

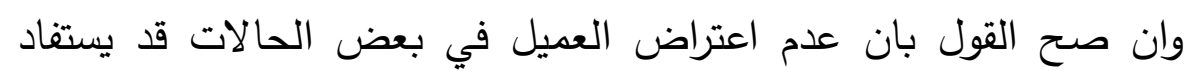

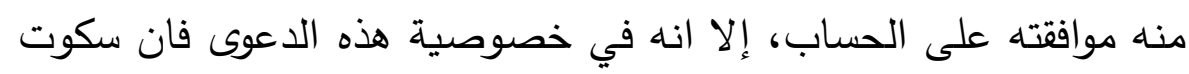

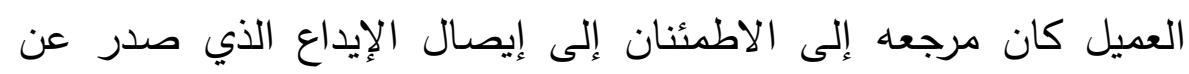

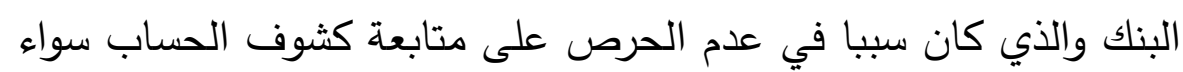

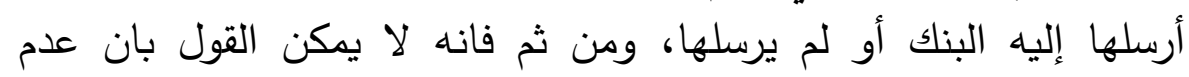

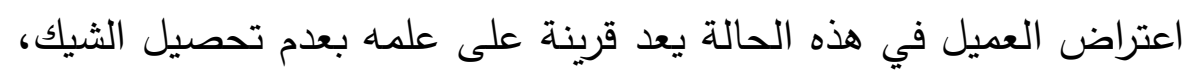
أو قبولا للحساب.

كذلك يكون البنك مسؤول عن عدم رد كافة المستندات التي وقعت

تحت يده اثناء تنفيذ عمليه التحصيل (').

\section{الامطاب الثالث}

\section{اعفاء البنك هن المسؤولية الناشئة عن عقد تمصيل الأوراق التجارية}

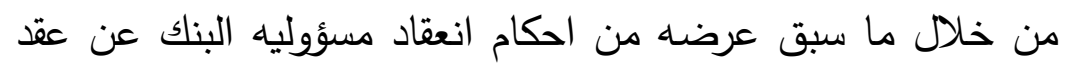

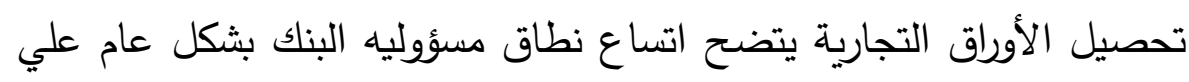

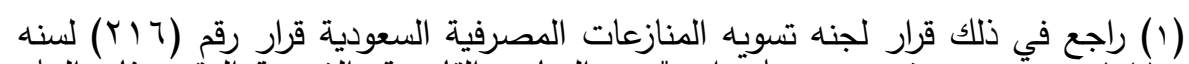

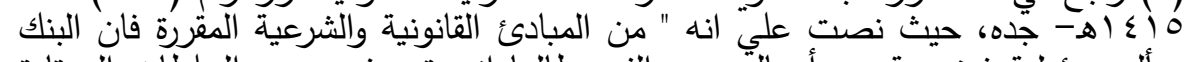

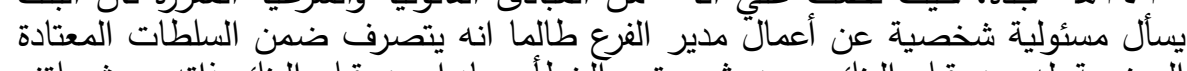

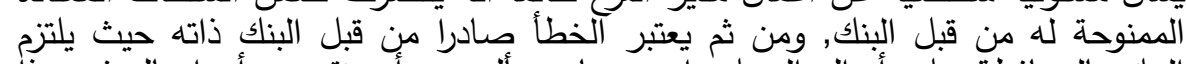

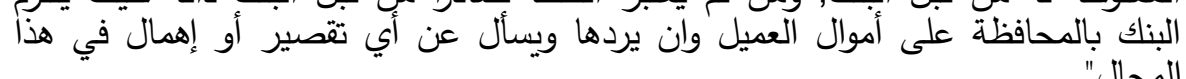


اعتبار انه شخص مهني محترف يجب عليه تحمل مخاطر مهنته، وايضًا عله

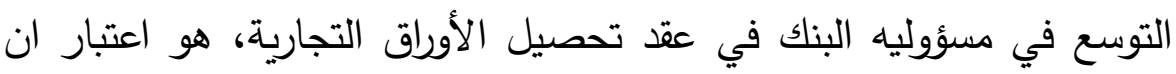

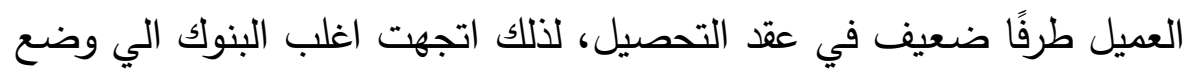

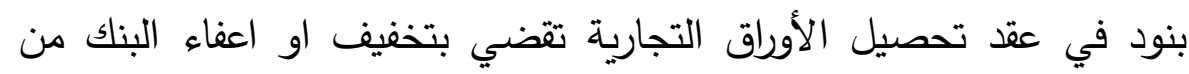
مسؤوليته عن بعض الالتزامات الواردة في عقد التحصيل تجاه العميل (').

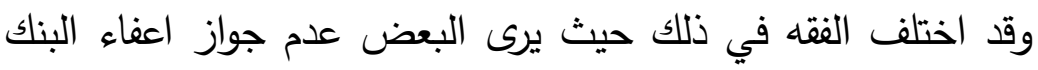

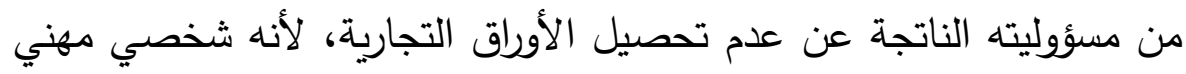

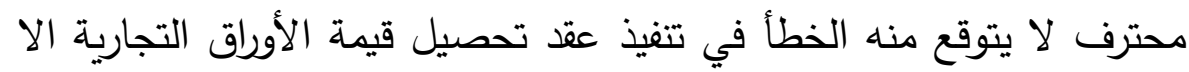
في حالات نادرة او في حاله توفر السبب الأجنبي (r).

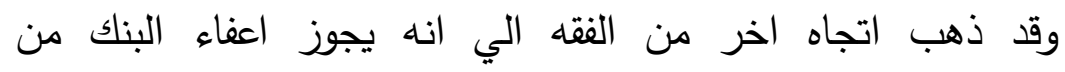
المسؤولية الناتجة عن عقد تحصيل الأوراق التجارية، وقد أسس ذلك الكانه الاتجاه

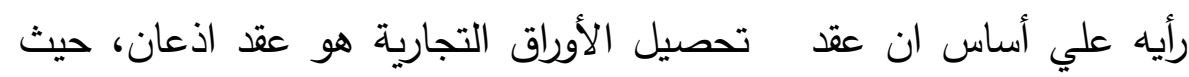

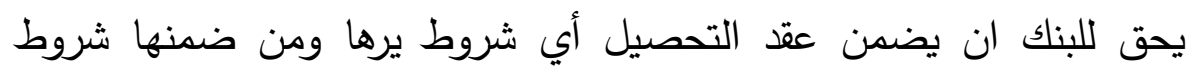
الاعفاء من المسؤولية، ولا يكون امام العميل مناقثه تلك الثروط ولكن علئ عليه ان يقبل العقد بكل شروطه او يرفضه.

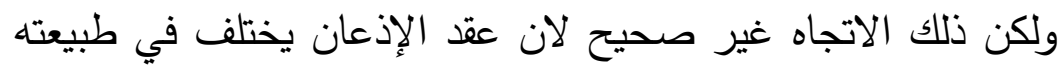

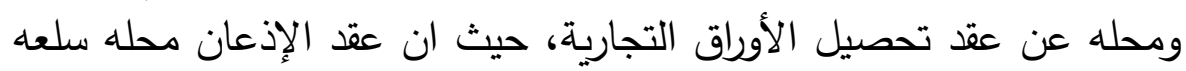

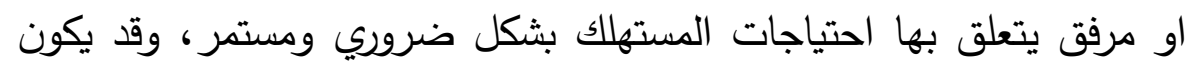

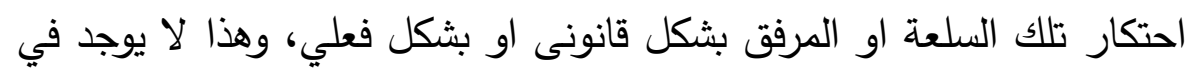

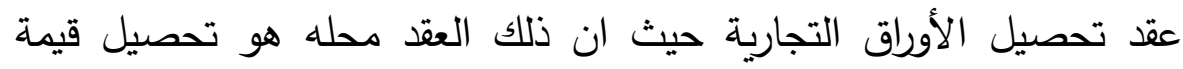

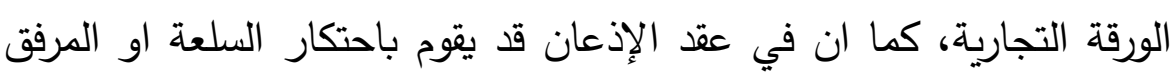
شخص واحد فقط بعينه، بعكس عمليه تحصيل الأوراق التجارية التي تقوم بها باليا

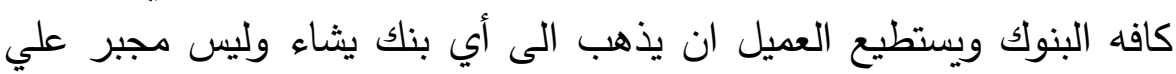

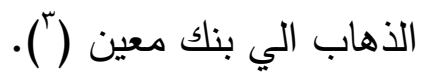

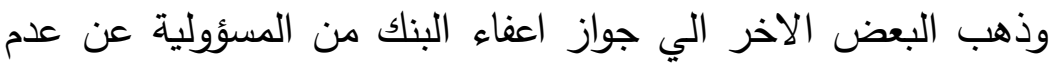
تحصيل قيمة الأوراق التجارية، وقد دعم ذلك الاتجاه رأيه علي أساس ان الن عقد الأن 1)( Ripert, Georges, Roblot, René, Op. Cit. p136. ص با د. حسن حسنى، الخدمات المصرفية في البنوك، رساله دكتوراه، جامعه عين شمس، 
تحصيل الأوراق التجارية هو وليد أراده طرفيه العميل والبنك (')، كما ان ان التئ

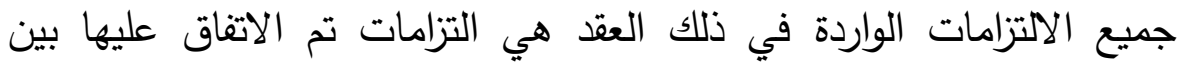

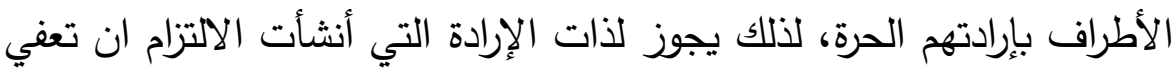

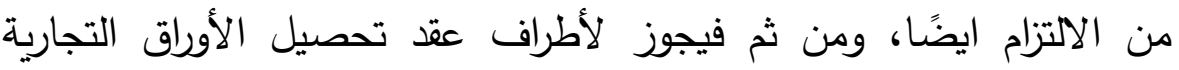

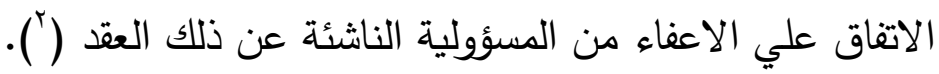

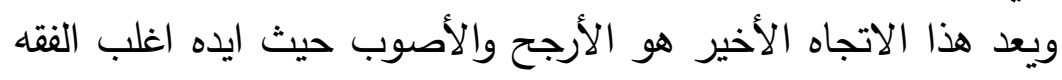

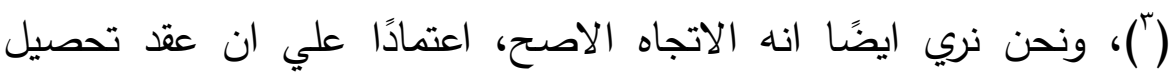

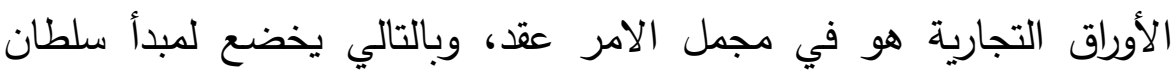

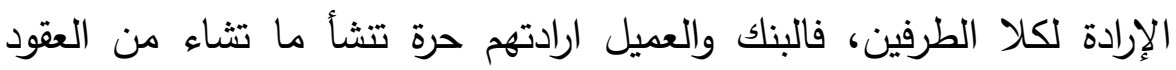

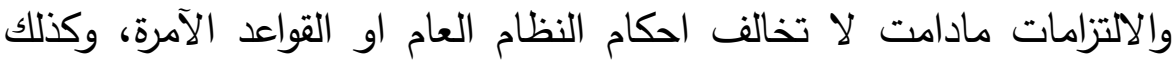

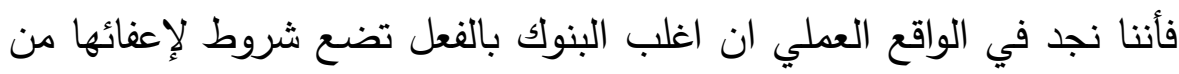
المسؤولية في اغلب عملياتها المصرفية ومن ضمنها عقد تحصيل الأوراق التجارية (أ).

\section{• نطاق شرط اعفاء البنك من المسؤولية الناشئة عن عقد تحصيل}

\section{الأوراق التجارية.}

إذا ما انتهينا الي جواز اعفاء البنك من مسؤوليته عن عقد تحصيل الأوراق التجارية، فهل يجوز ان يعفي البنك نفسه من المسؤولية بشكل تام التهاء

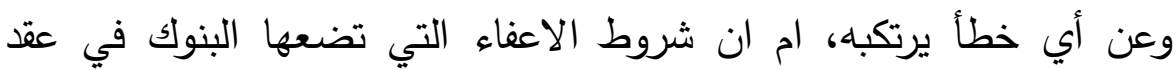

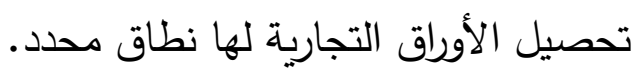

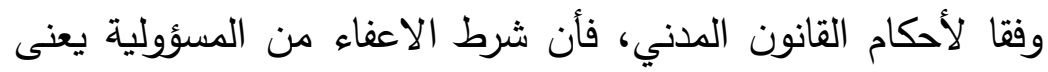

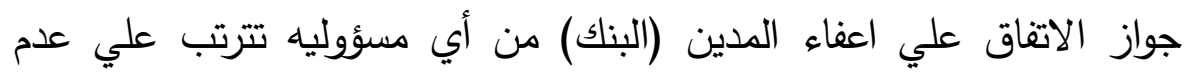

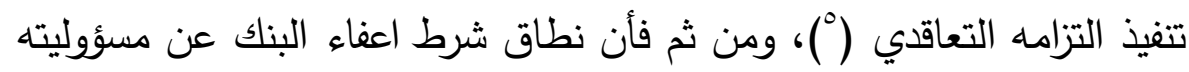

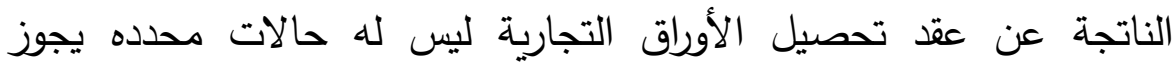

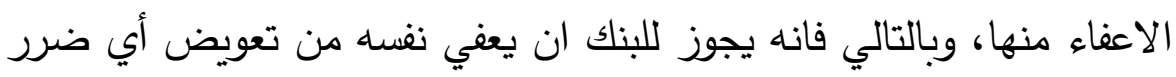

1) (ESSAM EL KALYOUBI, Op. Cit. p 276.

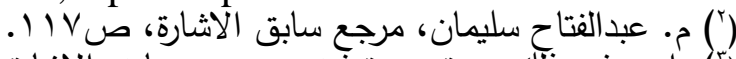

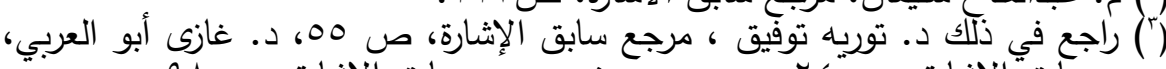

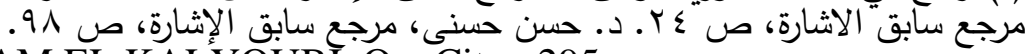
4) (ESSAM EL KALYOUBI, Op. Cit. p 295.

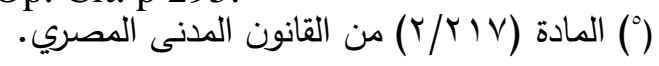


يقع علي العميل بسبب اخلاله بتتفيذ التزاماته في عقد تحصيل الأوراق

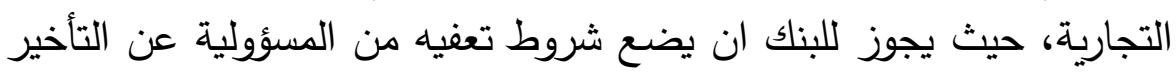

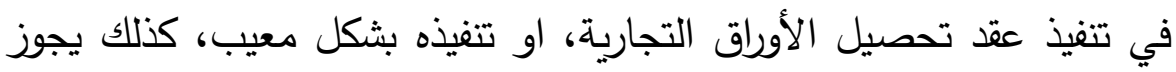

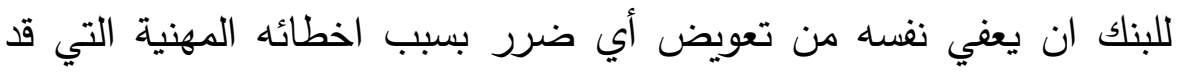

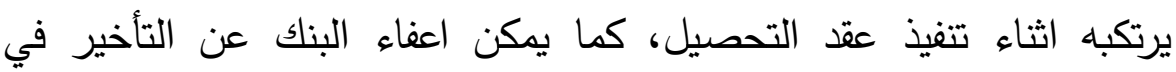

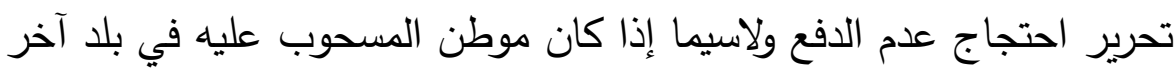

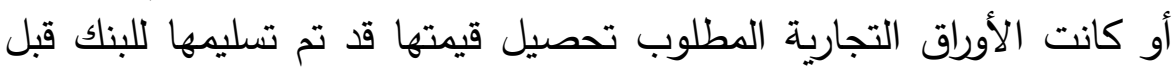

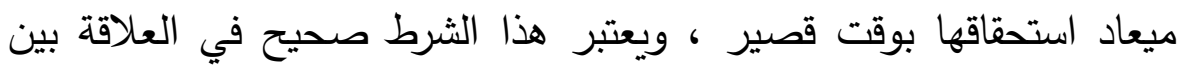
البنك والعميل دون الموقعين الآخرين على الورقة التجارية.

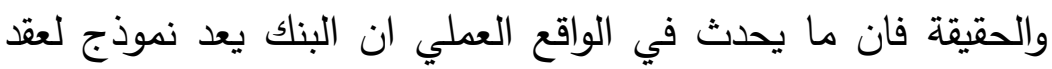

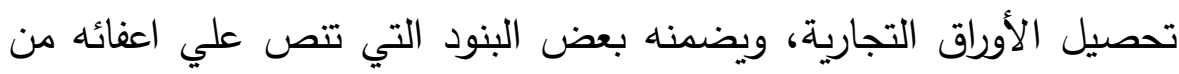

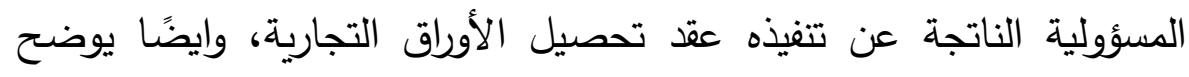

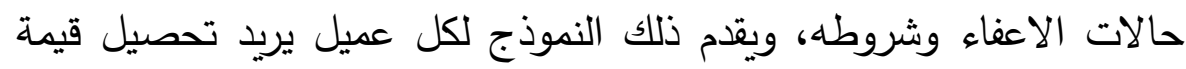

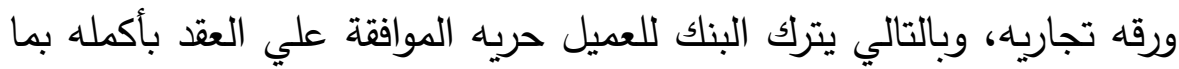

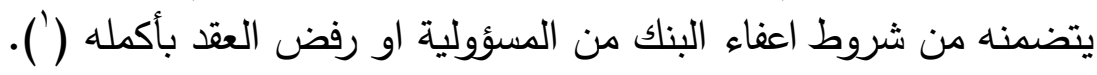

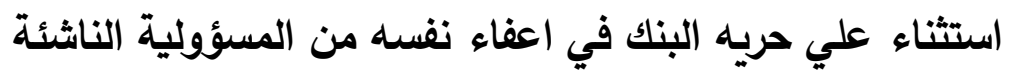
عن عقد تحصيل الأورلق التجارية.

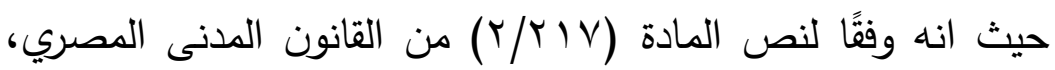

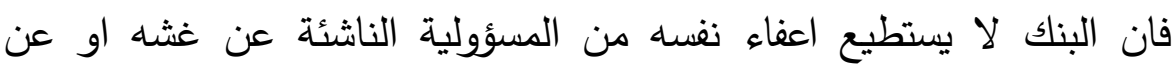

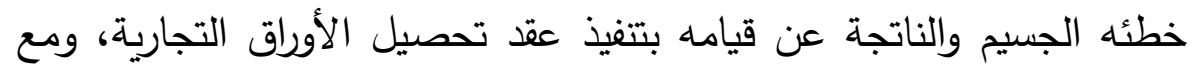

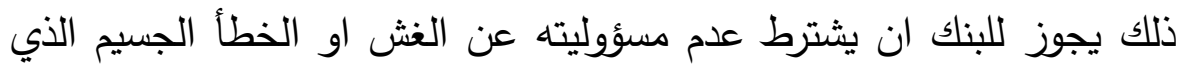

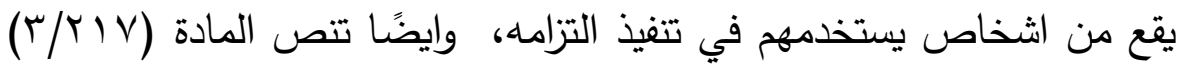

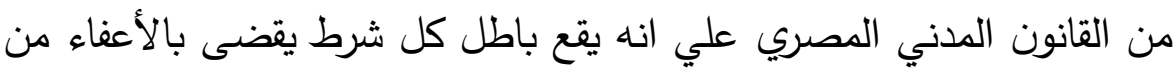

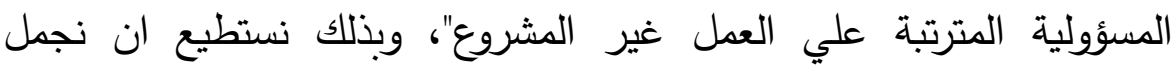

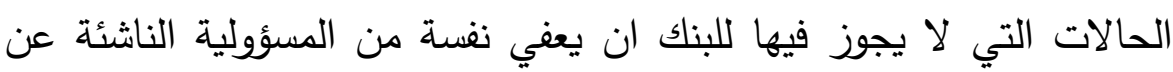
عقد تحصيل الأوراق التجارية فيما يلي: لاليك ان لعفي

(') د. توريه توفيق ، مرجع سابق الإثارة، ص 1 ص. 
ال - لا يجوز للبنك ان يعفي نفسه من المسؤولية الناتجة عن

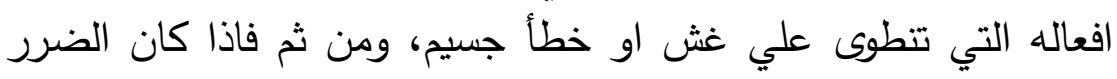
الواقع علي العميل من البنك سببه هو غش غش البن البك او خطأه المهنى

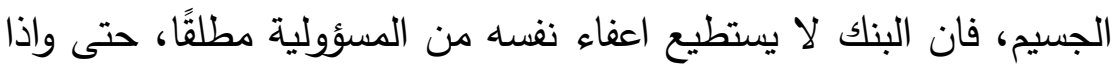
نص في عقد تحصيل الأوراق التجارية علي الاعفاء من تلك المسؤولية

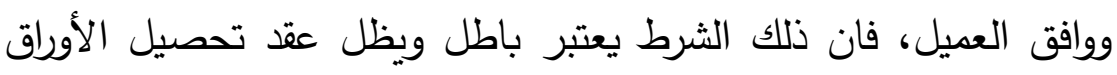

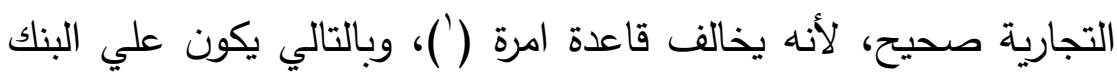
تعويض العميل عن ذلك الضرر الذي ينشأ بسبب غش البنك او ارتكابه

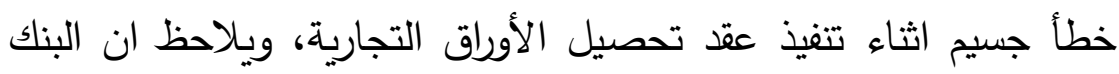

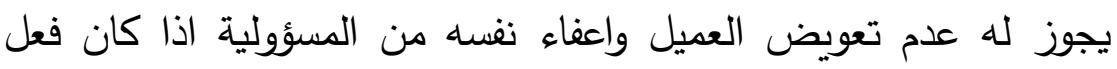
الغش او الخطأ الجسيم قد وقع من اشخاص يستخدمه البنك في تتفيذ

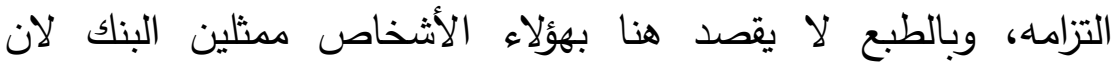

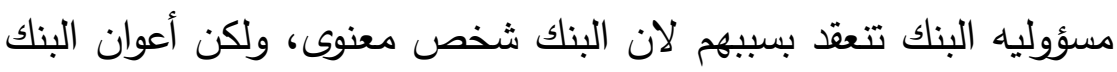

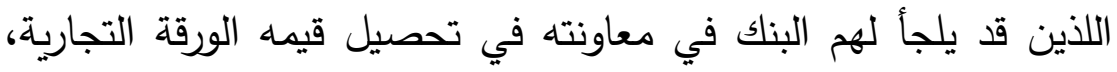

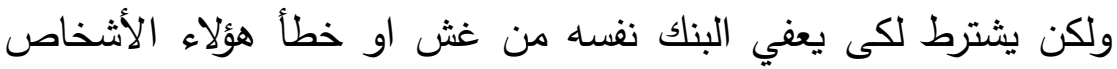

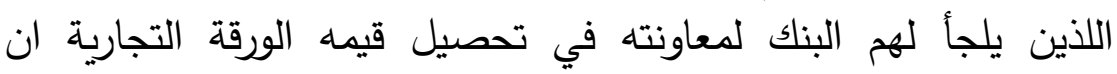

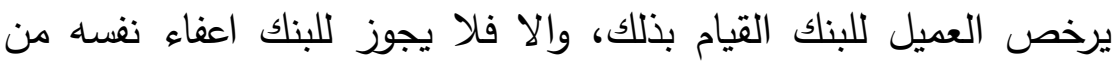
المسؤولية عن أفعال هؤلاء الأشخاص التي تنطوى علي غش الت او خطأ

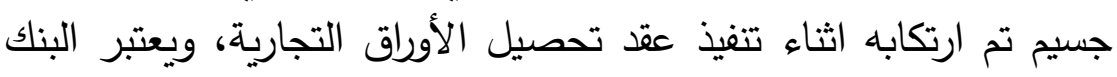

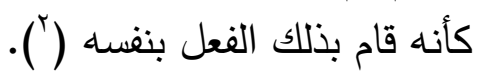
r- كذلك فانه لا يجوز للبنك اعفاء نفسه من المسؤولية المترتبة علي أي فعل او عمل غير المشروع يقع منه عند تنفيذ عقد تحصيل

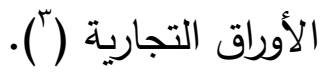

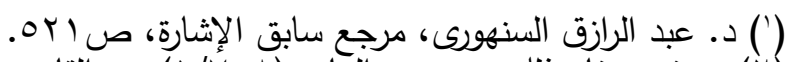

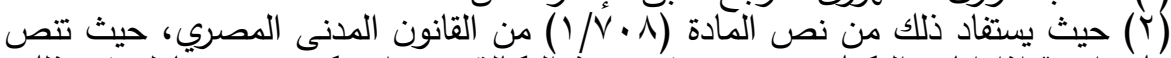

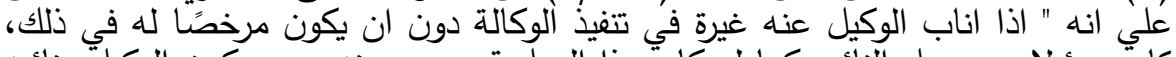

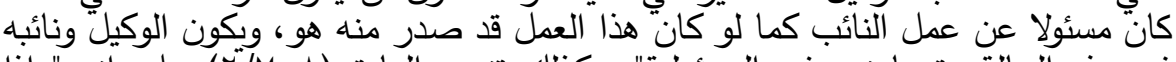

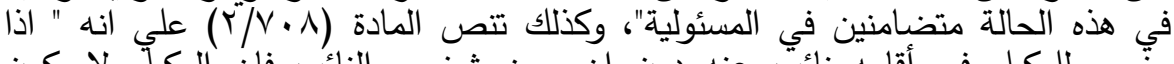

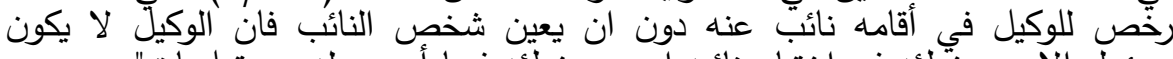

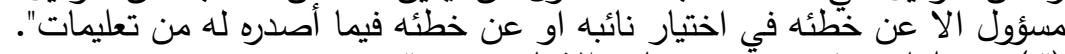

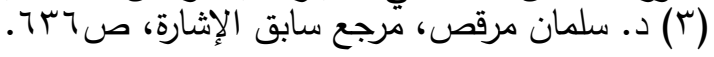




\title{
المبيث الرابع
}

انقضاك عقد تشصيل الأوداق التجارية واثرة علي مسوفلية البنك

\author{
تمهيد وتقسيم.
}

عقد تحصيل الأوراق التجارية كغيرة من العقود يخضع للأحكام العامة

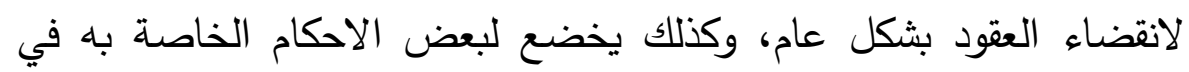

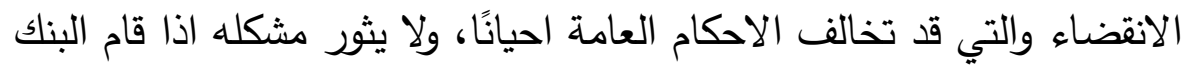

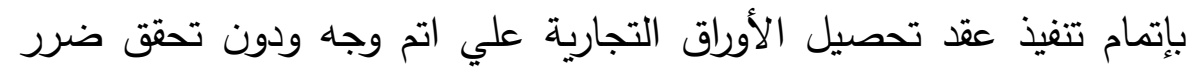

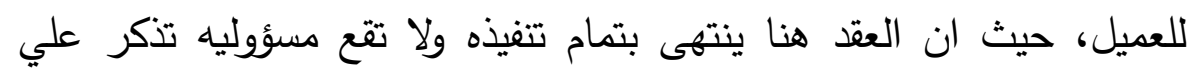

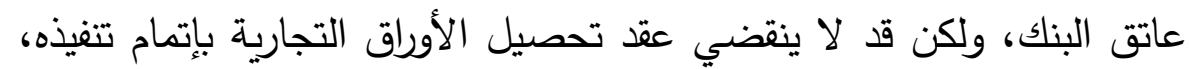

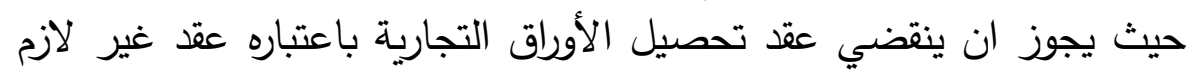

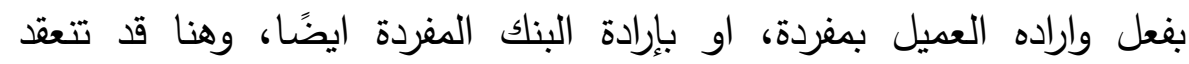
مسؤوليه البنك، وسوف نوضح الحالات التي ينقضى فيها عقد تحصيل

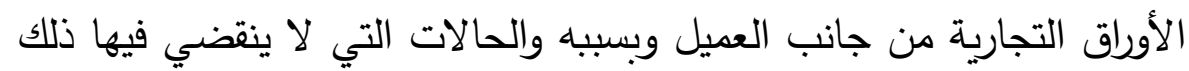
العقد، واثر ذلك علي مسؤوليه البنك في كافة الحالات (المطلب الأول).

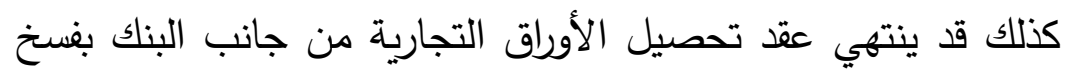
العقد، او بإفلاس البنك، او بسبب استحاله تتفيذ عقد تحصيل الأوراق التجارية

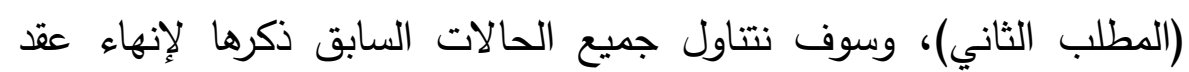

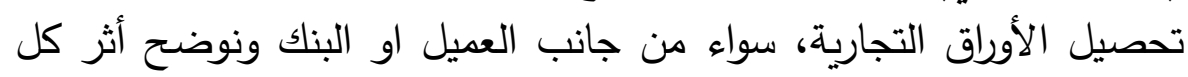
ذلك علي قيام مسؤوليه البنك من عدمه.

\section{الإطاب الاول عدمله}

\section{انقضاء عقد تهصيل الأوراق التجارية هن جانب العميل وأثر ذلك

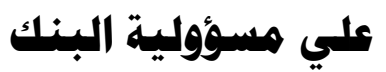

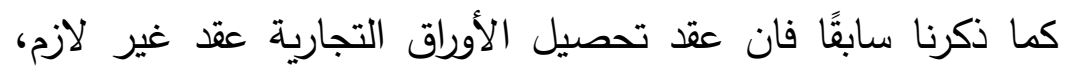

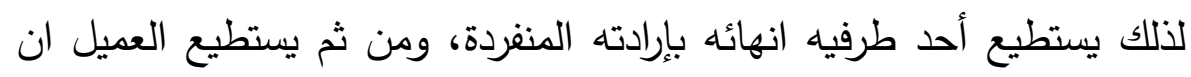

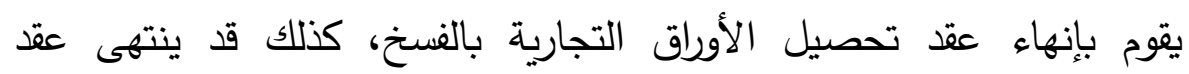

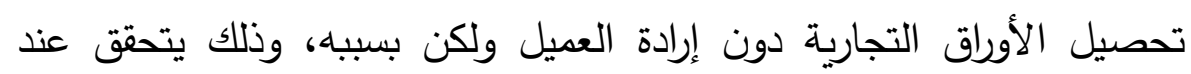

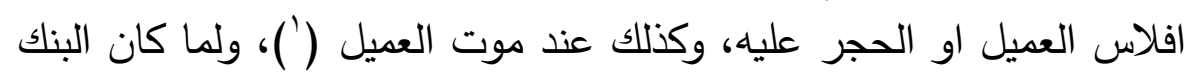

1) (ESSAM EL KALYOUBI, Op. Cit. p 280. 
هو الطرف الاخر في ذلك العقد فانه قد يتأثر بذلك الانهاء، ولكن ما يهمنا

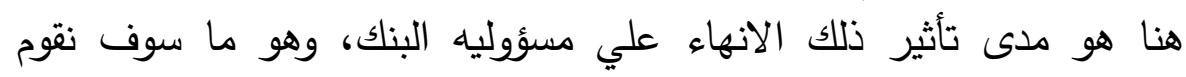
بتوضيحه فيما يلي.

اولاً: انقضاء عقد تحصيل الأوراق التجارية بإرادة العميل المنفردة

$$
\text { وأثر ذلك علي مسؤوليه البنك. }
$$

يستطيع العميل ان يقوم بفنخ عقد تحصيل البك الأوراق التجارية من تلقاء نفسه ودون الرجوع الي البنك في ذلك، باعتبار ان عقد تحصيل قيمة الأوراق الته

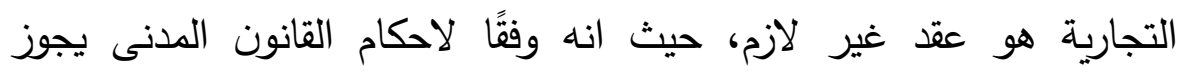

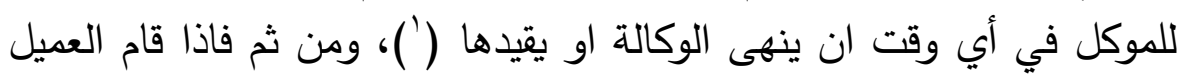

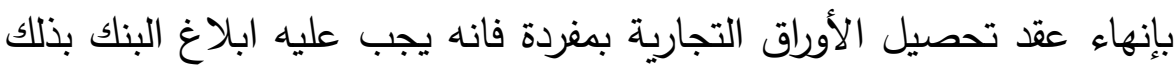
الانهاء، وذلك حتى يمتتع البنك عن القيام بمهمته في عمليه التحصيل

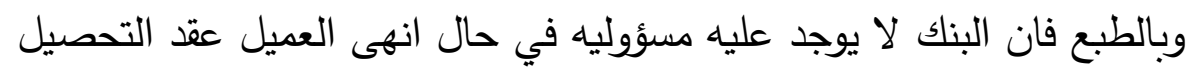

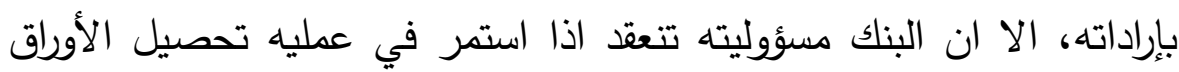

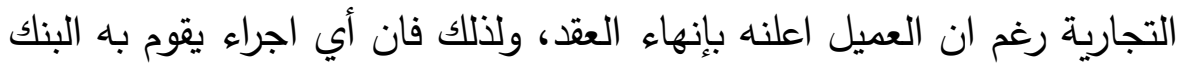

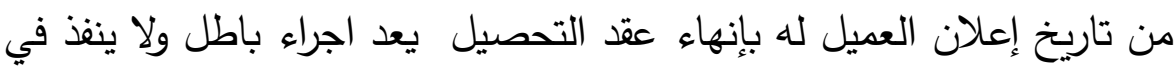

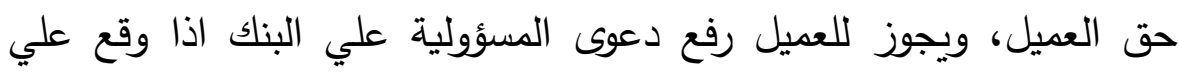
العميل ضرر بسبب استمرار البنك في تتفيذ عقد تحصيل الأوراق التجارية

كذلك يجب علي البنك اذا قام العميل بإعلانه بالإنهاء ان يسلم

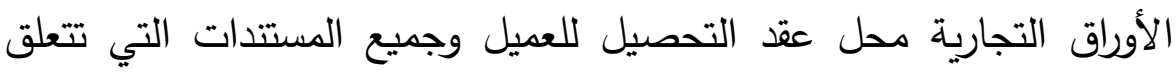

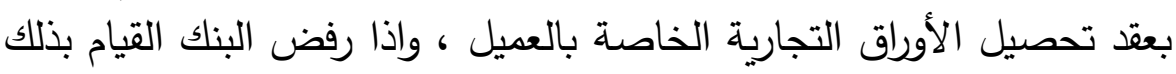

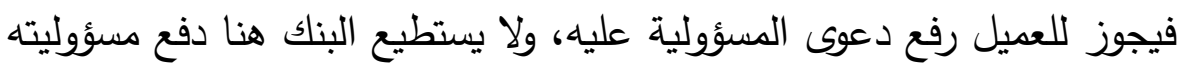

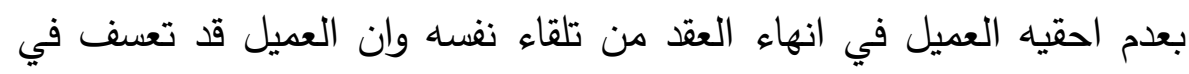

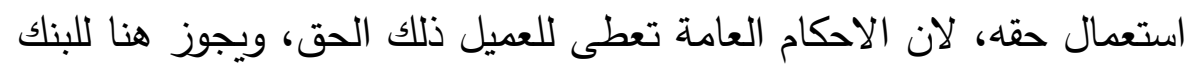

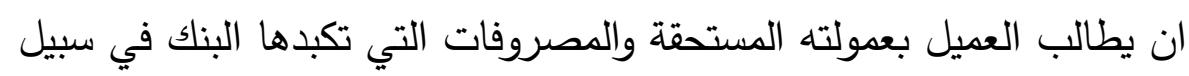
قيامه بتحصيل قيمة الورقة التجارية حتى تاريخ انهاء العميل لعقد التحصيل.

2)( Ripert, Georges, Roblot, René, Op. Cit. p187.

(1) (1/1010) من القانون المدنى المصري. 
ثانيًا: افلاس العميل او الحجر عليه وأثره علي انقضاء عقد تحصيل الأولق التجارية وعلي مسؤوليه البنك. الحجر هو عباره عن منع الثخص من التصرف في أمواله، وقد التد يكون الحجر علي الثخص لمصلحه نفسه، كالحجر علي المجنون او السفيه

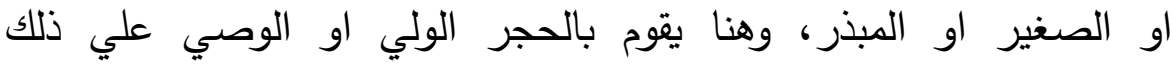

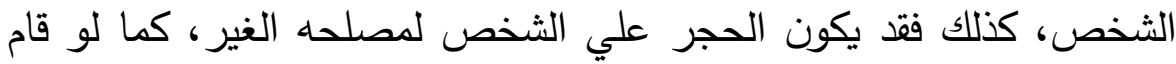

الدائنين بالحجر او الحجز علي أموال مدينهم المفلس لاستيفاء ديونهم ( '). وقد يتعرض العميل الذي قام بإبرام عقد تحصيل الأوراق التجارية

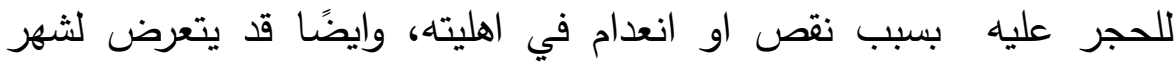

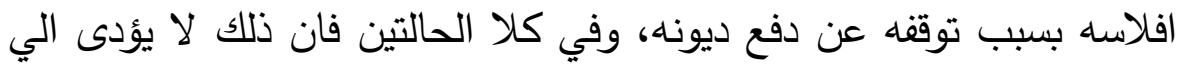

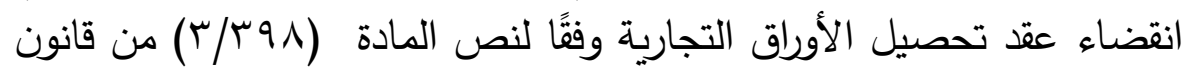

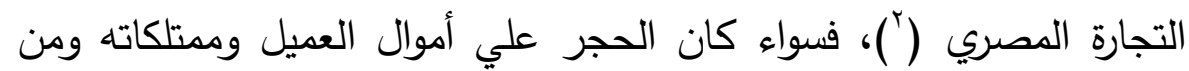

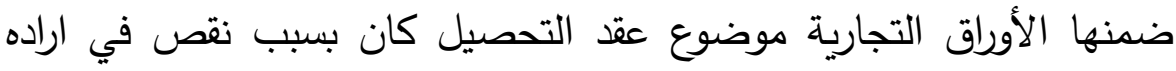
العميل او افلاسه، فان القاضي هو الذي يصدر الحكم بذلك ومن ثم يعيين

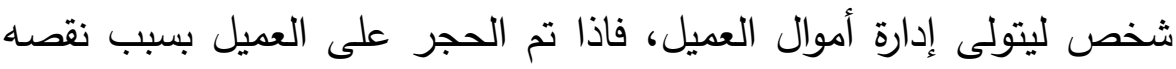
في اهليته فان القاضي يقوم بتعيين وصي او ولي يتولى اداره أموال العميل

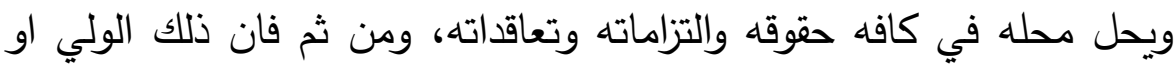
الوصي يحل محل العميل في عقد تحصيل الأوراق التجارية، ويكون لله كافه ونه

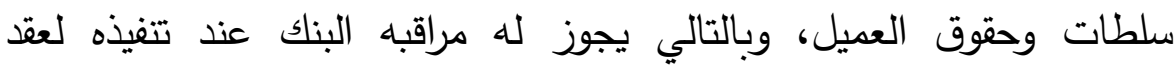

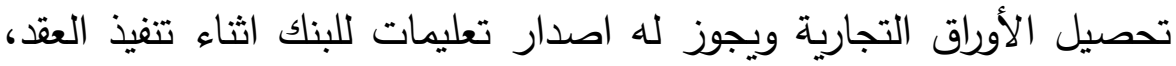

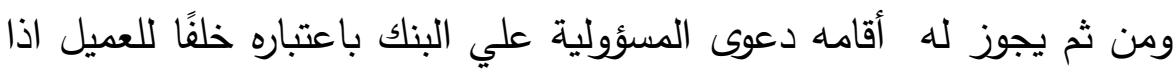

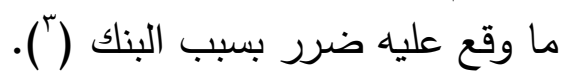

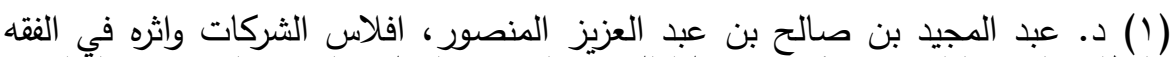

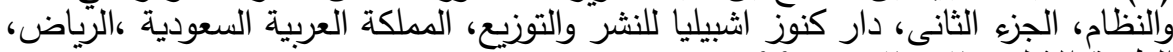

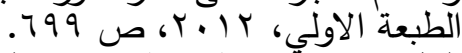

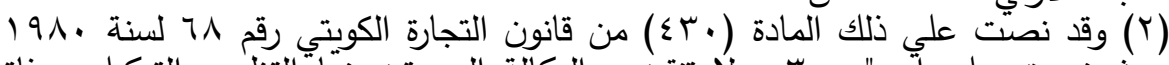

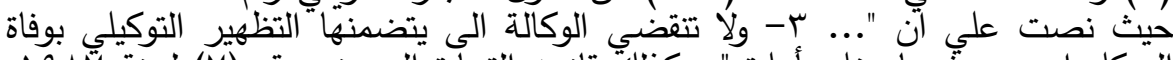

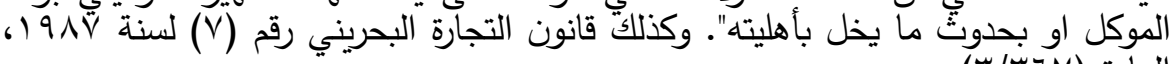

Ripert, Georges, Roblot, René , Delebecque, Philippe, Germain, Michel, Traité de droit commercial [Texte imprimé]. Tome 2. Valeurs mobilières, effets de commerce,Paris. 1998. P. 265. 
كذلك فاذا أفلس العميل وتم شهر افلاسه، فلا ينقضي عقد تحصيل

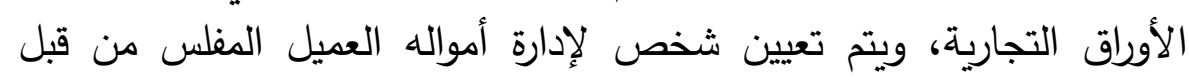
الائنين يسمى وكيل التفليسة ('). ويلاحظ انه قد يتأثر عقد تحصيل الأوراق التجارية بإفلاس العميل

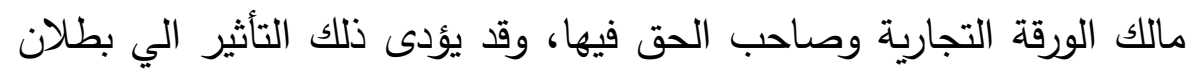

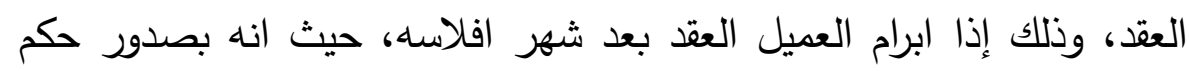

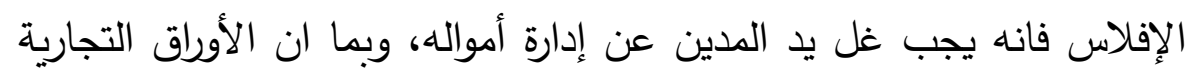

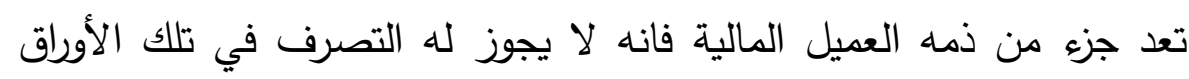

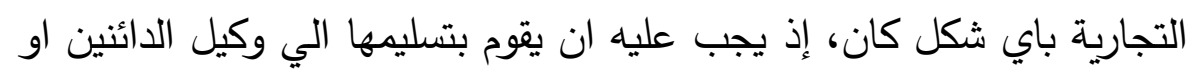
وكيل التفليسة ليتولى هو عمليه تحصيلها. ومن ثم فاذا قام البنك بإبرام عقد تحصيل الأوراق التجارية مع العميل المفلس وهو علي علم بصدور حكم شهر افلاسه، وقام بتحصيل قيمه الورقة التجارية لمصلحه العميل، فهنا تثور مسؤوليه البنك، ولكن ليس في مواجهاه

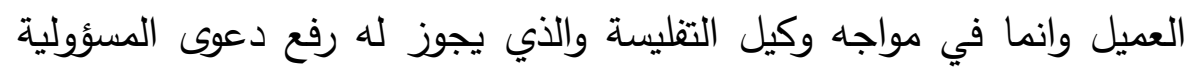
علي البنك لتوفر سوء النية في حقه وايضًا لمساهمته في تبديد أموال الدائنين

اما إذا كان عقد تحصيل الأوراق التجارية قد تم ابرامه قبل افلاس

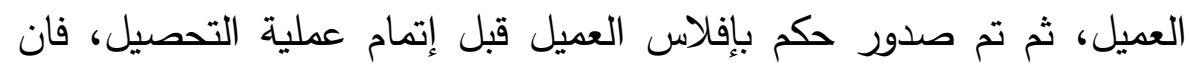

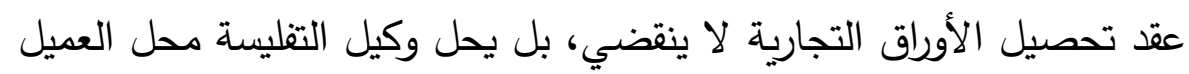

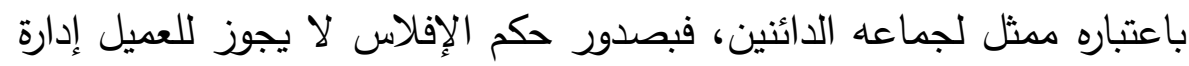

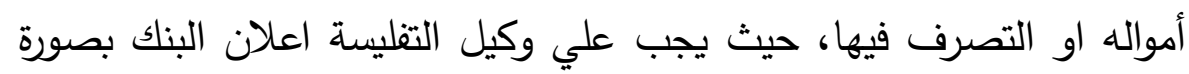
رسميه من حكم شهر افلاس العميل (").

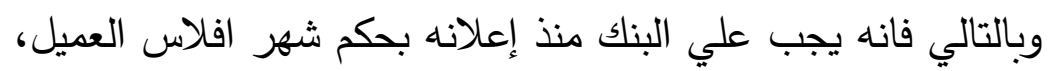

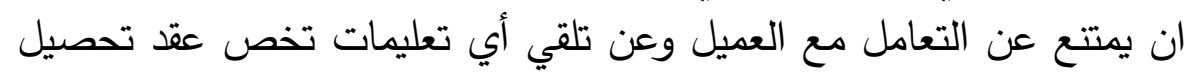

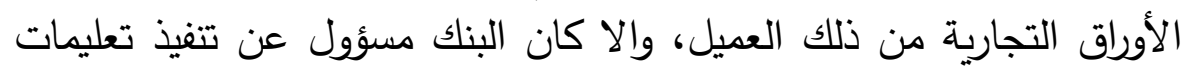
العميل التي يترتب عليها وقوع ضرر علي الدائنين، حيث يجب التبن علي البنك ان ان

(1) د. عبد المجيد بن صالح بن عبد العزيز المنصور ، مرجع سابق الإشارة، صY •. V. 2) (ESSAM EL KALYOUBI, Op. Cit. p 290.

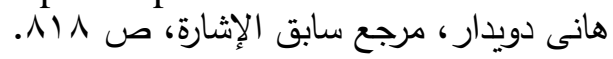


يتلقي تعليماته من وكيل التفليسة ويقوم بكافه الالتزامات التي كان يقوم بها في

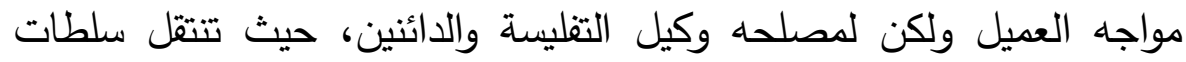
العميل الي وكيل التفليسة فيما يتعلق بعقد تحصيل الأوراق التجارية (')، ومن ولن التئل

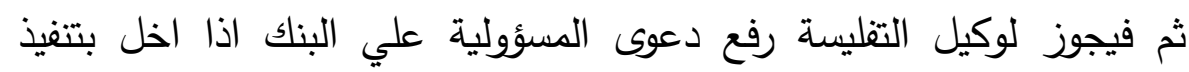

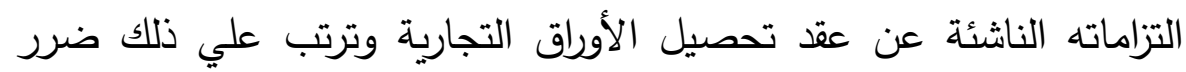

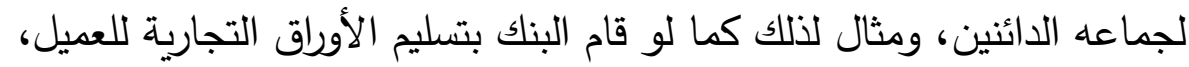

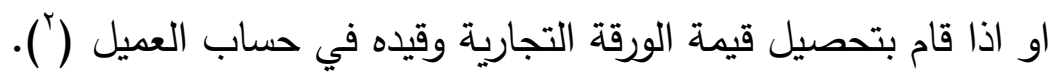
ثالثًا: موت العميل وأثره علي انقضاء عقد تحصيل الأورلق التجارية التهاء وعلي مسؤوليه البنك. وفقاً للقواعد العامة فان عقود الوكالات بثكل عام تتتهي بموت

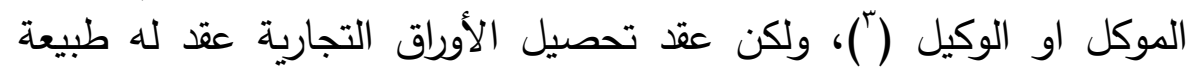

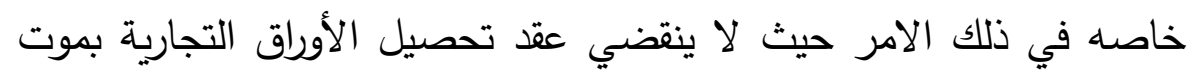

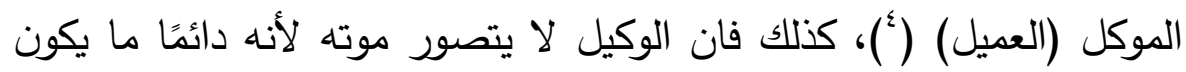
شخصيه معنويه (البنك)، ويرجع سبب عدم انقضاء عقد تحصيل الأوراق

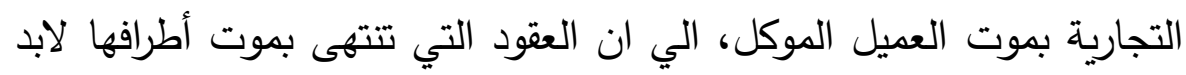

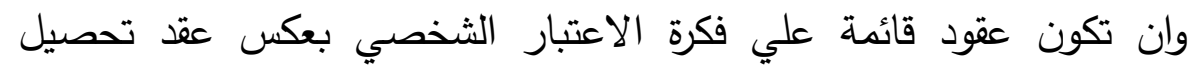

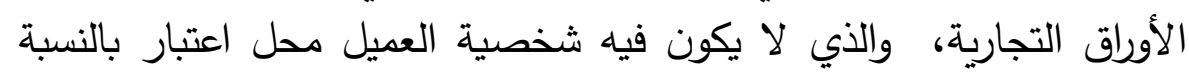

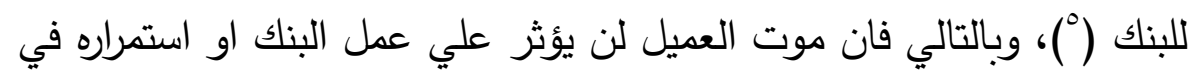

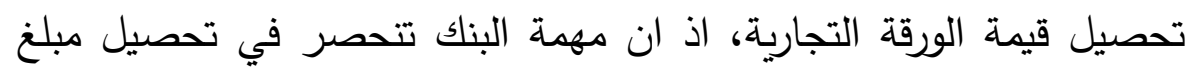

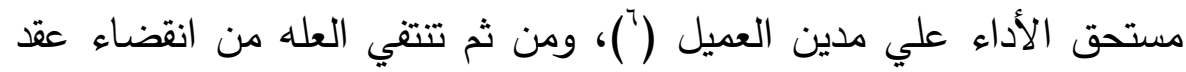
تحصيل الأوراق التجارية بموت الموكل اونين العمل العميل.

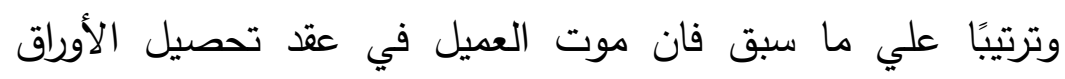
التجارية لا يؤدى الي انقضاء العقد، حيث يظل العقد قائم ومنتج لكافة اثارة

(1) د. حسين شحادة الحسيني، عمليات البنوك في المملكة العربية السعودية، الطبعة

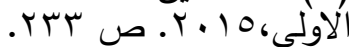

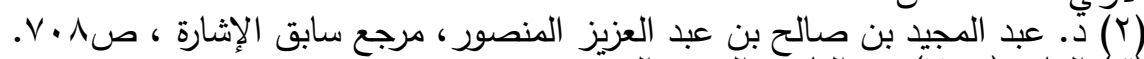

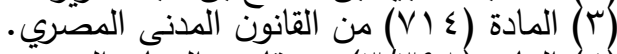

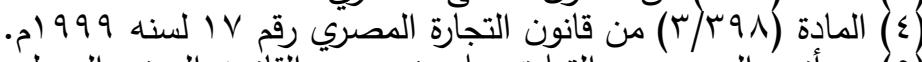

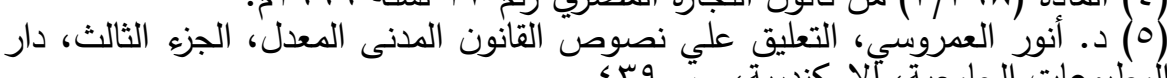

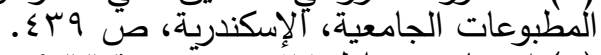

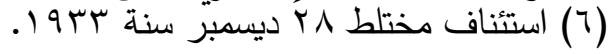


ولكن في مواجه الورثة، حيث يحل ورثه العميل محل العميل ويكون لهم كافة حقوقه وعليهم كافة واجباته تجاه البنك ('). وكذلك البنك يكون ملتزم امام الورثة بكافة الالتزامات التي كان ملتزم بها في مواجه العميل، وبانتقال سلطات العميل المتوفي الي ورثته في عقد الدئه تحصيل الأوراق التجارية، فانه يجوز للورثة رفع دعوى المسؤولية علي البنك الكان اذا وقع علي الورثة ضرر بسبب قيام البنك بتنفيذ عقد تحصيل الأوراق

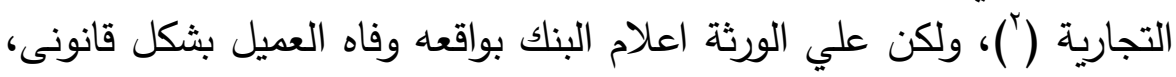

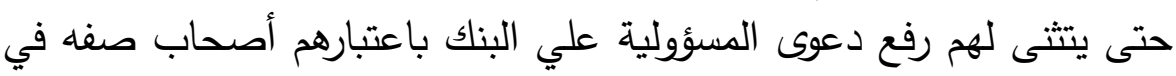

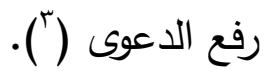

\section{الإلب الثاني}

\section{انقضاك عقد تهميل الأوراق التبارية من جانب البنك وأثر ذلاك علي معنو}

يجوز للبنك ان ينهى عقد تحصيل الأوراق التجاري بمفردة، وكذلك ينتهى عقد تحصيل الأوراق التجارية اذا افلس البنك، كما ينتهى عقد تلأنى تحصيل

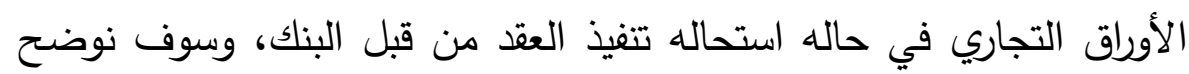
الحالات السابق اجمالها فيما يلي واثرها علي مسؤولية البنك.

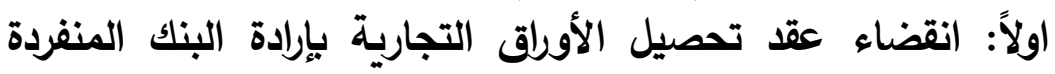
وأثر ذلك علي مسؤوليته.

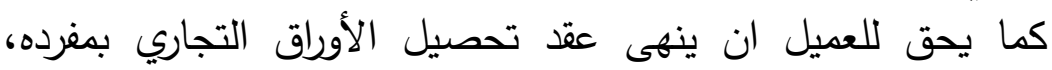
فكذلك يحق للبنك ان يقوم بإنهاء عقد تحصيل الأوراق التجاري بمفرده علي لأني

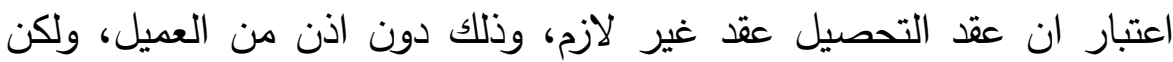

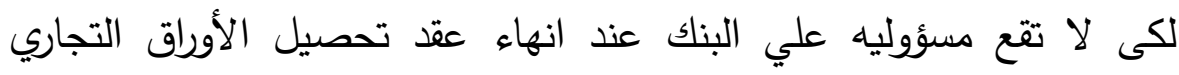

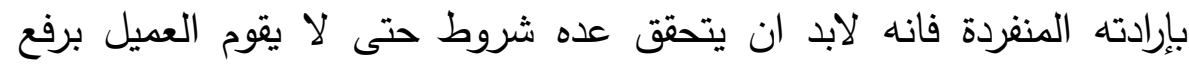

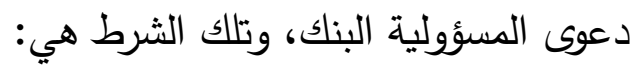

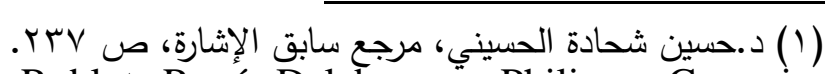
2) (Ripert, Georges, Roblot, René, Delebecquê, Philippe, Germain, Michel, Op. Cit. p. 279.

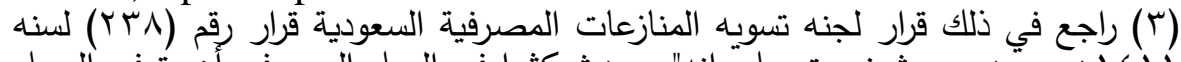

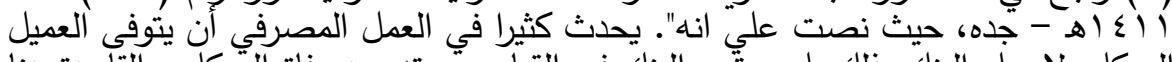

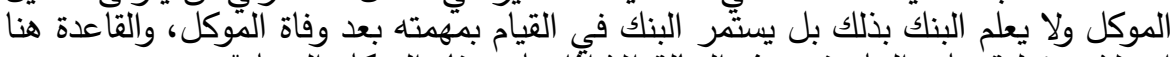
انه لا مسئولية على البنك في هذه الحالة إلا إدّا علم بوفاة الموكل العميل". 


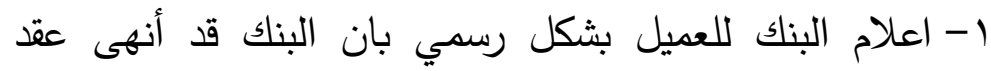

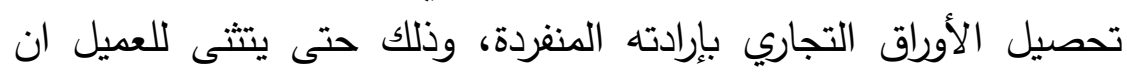
يدبر امره فيما يتعلق بتحصيل ورقته التجاري (').

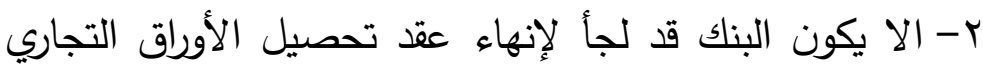
بإرادته المنفردة، بسبب ارتكابه خطأ جسيم، حيث ان سوء النية يتوفر هناء لإناء في حق البنك، لأنه يغلب على الامر ان البنك يريد التحلل من مسؤوليته الناتجة عن خطأه الذي ارتكبه، واخلاله بتتفيذ عقد تحصيل الألغات لأوراق

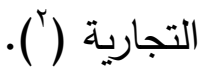

r- ان لا يتعسف البنك في استخدام حقه في انهاء عقد تحصيل

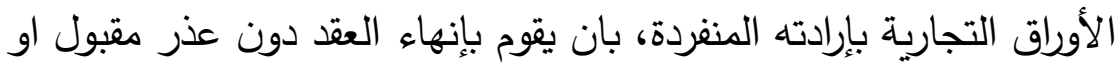

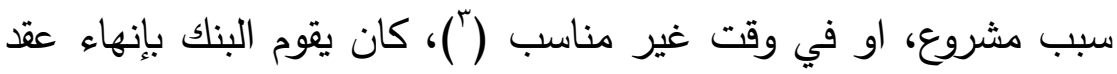
تحصيل الأوراق التجارية قبل مده قصيرة جدًا من موعد الاستحقاق، بحيث

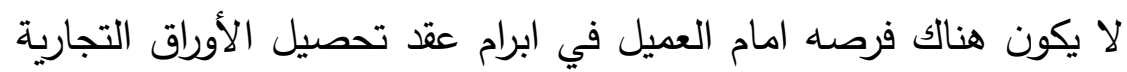

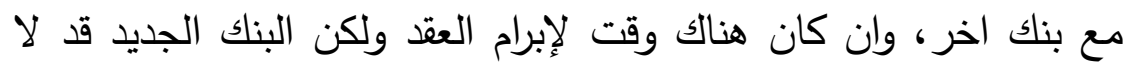

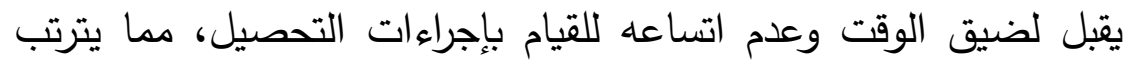

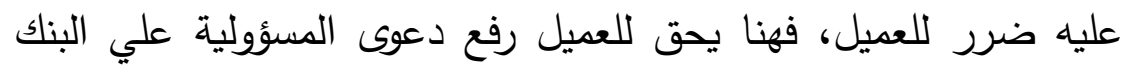
لتعويضه عن ذلك الضرر الذي تسبب فيه البنك، حيث يجب ديب علي البنك اذا إراد انهاء عقد التحصيل ان يصل بالأعمال التي بدأها في عمليه التحصيل الي الحالة التي لا يتعرض معها العميل للضرر من الانهاء

ع- ان يقوم البنك بتسليم العميل الأوراق التجارية وجميع

المستندات التي حصل عليها بموجب عقد تحصيل الأوراق التجارية، وايضًا أي أموال ناتجه عن عمليه تحصيل الأوراق التجارية ( (1).

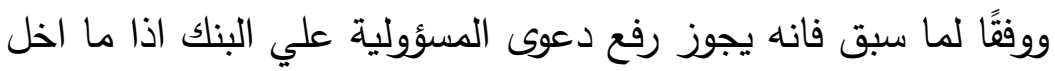

1) (Ripert, Georges, Roblot, René, Delebecque, Philippe, Germain, Michel, Op. Cit. p. 281.

2) (ESSAM EL KALYOUBI, Op. Cit. p 288. 
بإحدى هذه الشروط السابق ذكرها، وترتب علي ذلك الاخلال ضرر للعميل.

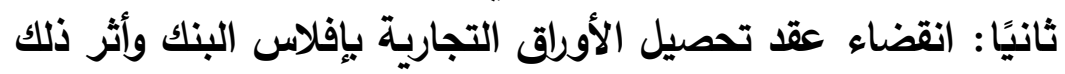

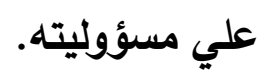

إذا تعرض البنك للإفلاس فانه بالطبع سوف يتوقف عن مزاوله كافة انشطته وخدماته المصرفية، ومن ثم سوف يتوقف عن تنفيذ عقد تحصيل

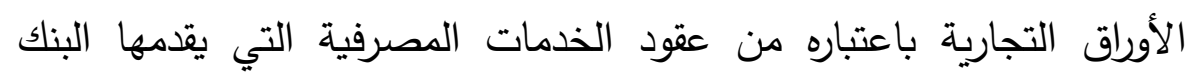

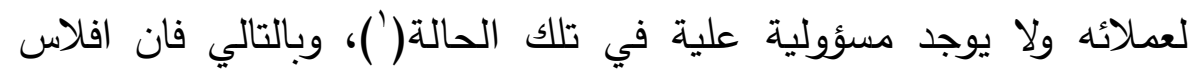

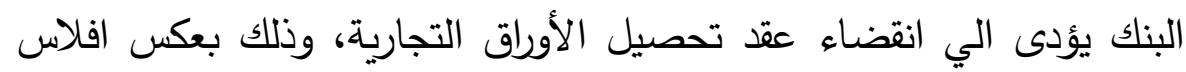
العميل كما سلف الذكر لا يؤدى الي انقضاء عقد تحصيل الأوراق التجارية

\section{ثالثُا: انقضاء عقد تحصيل الأورلق التجارية بسبب استحاله تنفيذ}

البنك للعقد وأثر ذلك علي مسؤوليته.

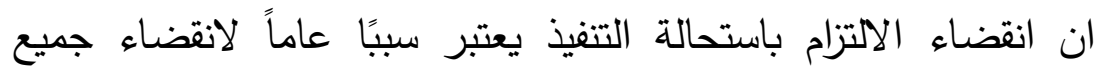

العقود بشكل عام، لذلك فهو ينطبق علي عقد تحصيل الأوراق التجارية باعتباره

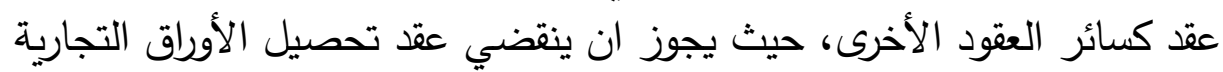

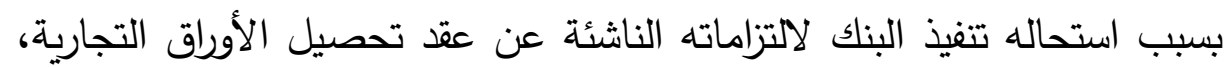

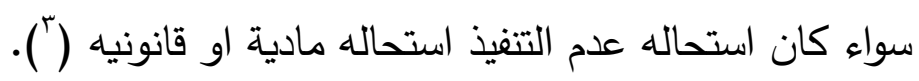

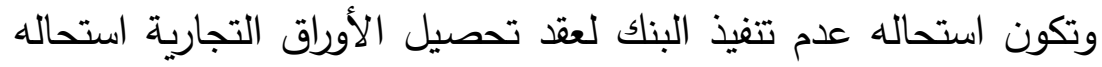

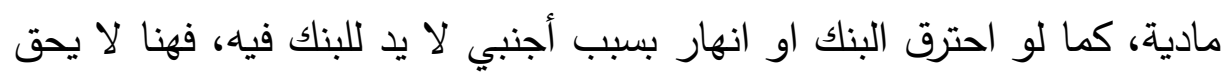

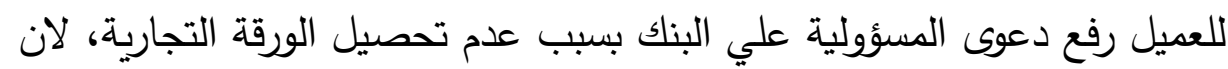

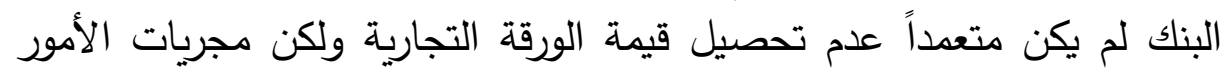

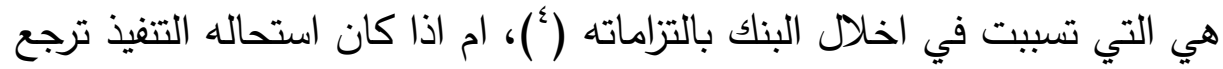

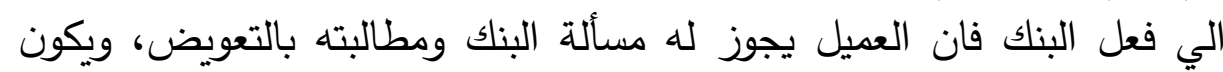

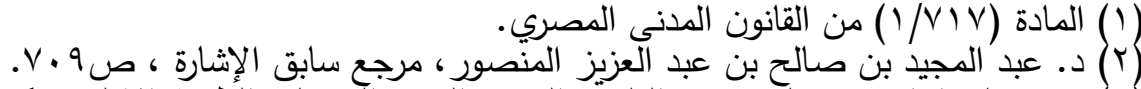

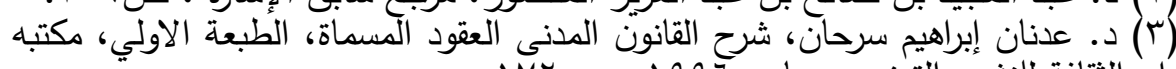

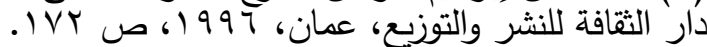

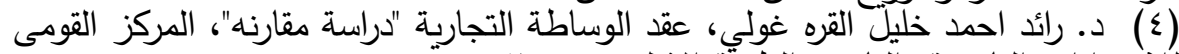

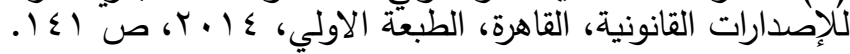


علي البنك ان يثبت السبب الأجنبي حتى يدفع المسؤولية عن كاهله ( '). كذلك قد تكون استحاله عدم تتفيذ البنك لعقد تحصيل الأوراق التجارية استحاله قانونيه، كما لو تم وضع البنك تحت الحراسة القضائية علي سبيل المثال ،او تم منع البنك من مزاوله العمليات المصرفية بسبب مخالفته القوانين

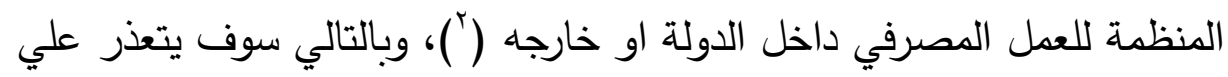

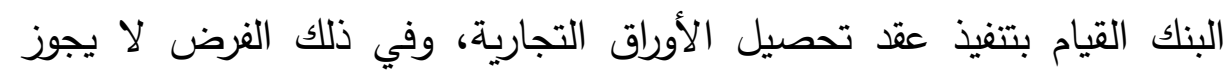

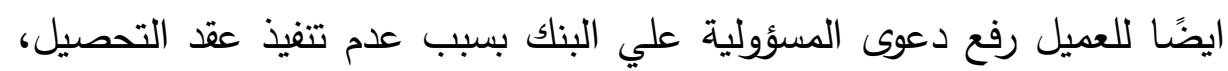

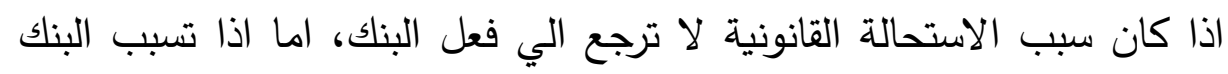
بسوء تصرفه وبفعله في منعه من مزاوله النشاط المصرفة علي سبيل المثال بسبب مخالفته القوانين المنظمة للعمل المصرفي، فهنها يجوز للعميل ان ان يرفع

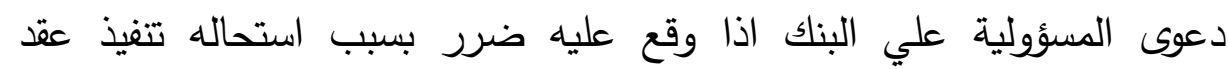

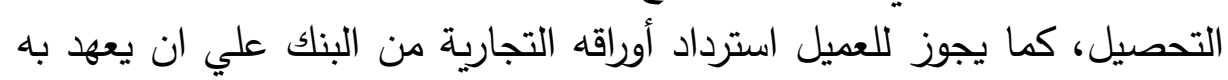
لبنك اخر لكى يقوم بتحصيلها (r).

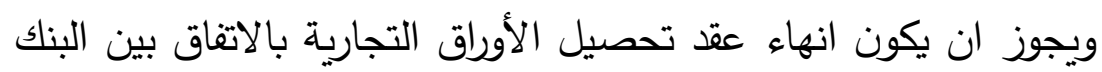

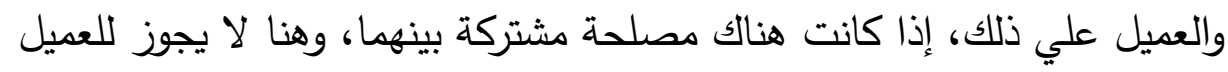

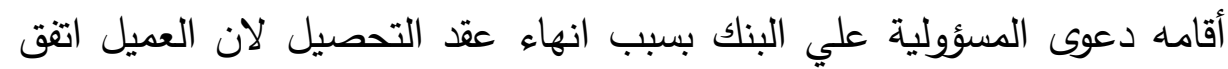

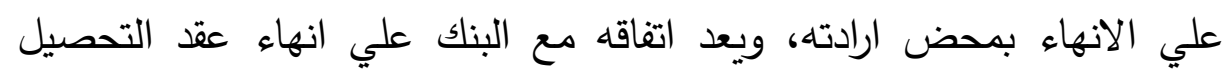

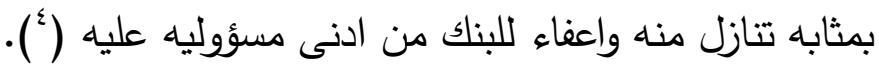

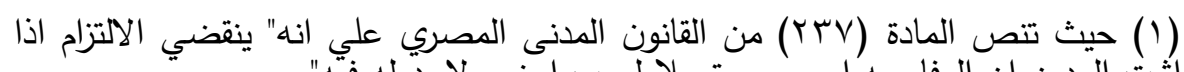

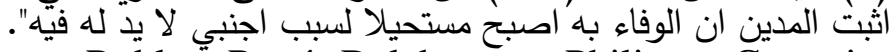

2) (Ripert, Georges, Roblot, René, Delebecque, Philippe, Germain, Michel, Op. Cit. p. 283.

د. دائد احد خليل القره غولي، مرجع سابق الاشارة، ص • •ـ ا.

4) (ESSAM EL KALYOUBI, Op. Cit. p 289. 


\section{الخــاتمسة}

النتائج:

توصلنا من خلال دراستنا الي ما يلي:

- - ان العلاقة بين البنك والعميل فيما يتعلق بتحصيل الأوراق

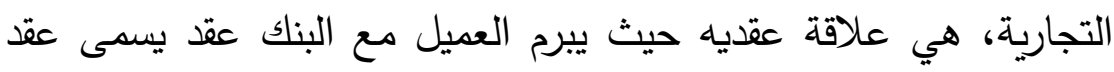

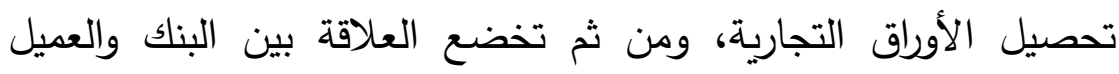
لأحكام ذلك العقد.

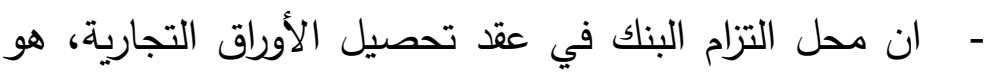

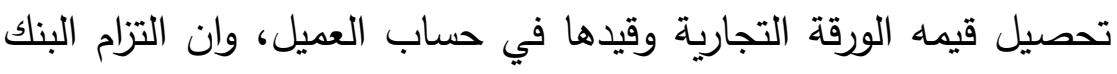

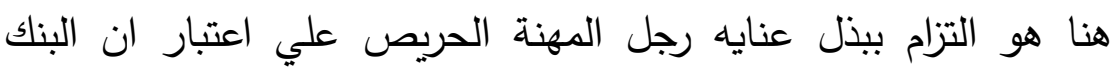

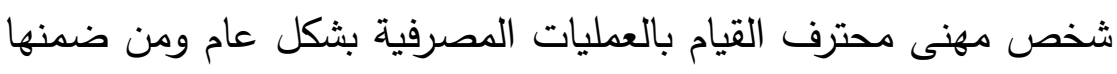
عمليه تحصيل الأوراق التجارية.

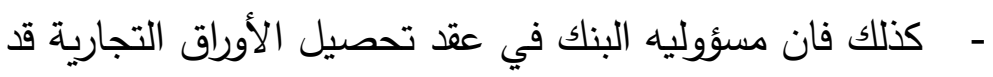

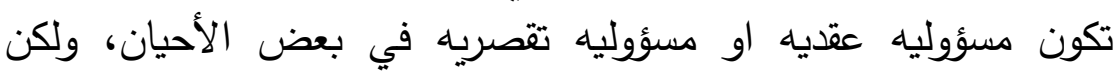
الغالب هو تأسيس مسؤوليه البنك علي أساس المونيه أنوأولية العقدية.

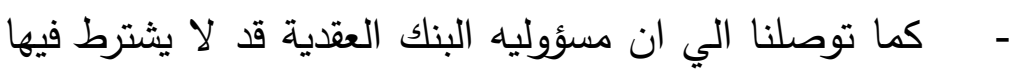

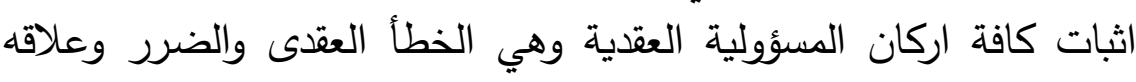

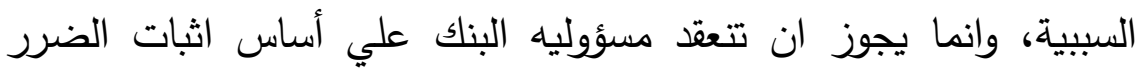

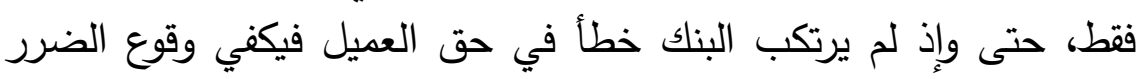

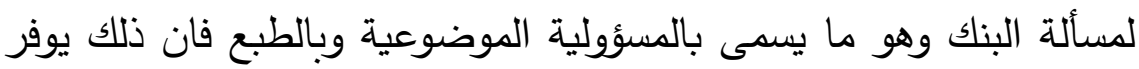

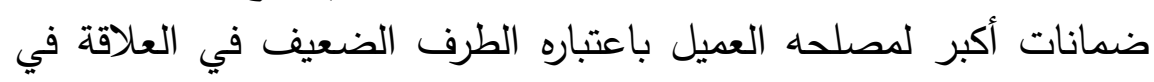
مواجهه البنك.

كنلك فان مسؤوليه البنك قد تنعقد منذ ان يتسلم البنك الورقة

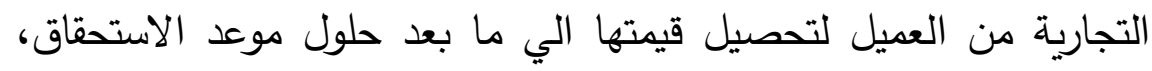

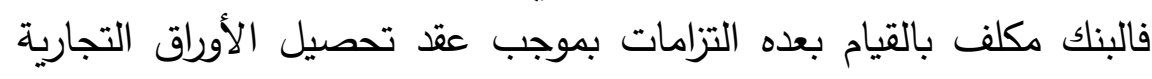
فاذا ما اخل بتلك الالتزامات انعقدت مسؤوليته تجاه العميل.

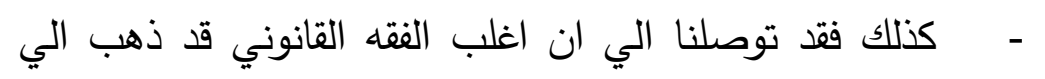

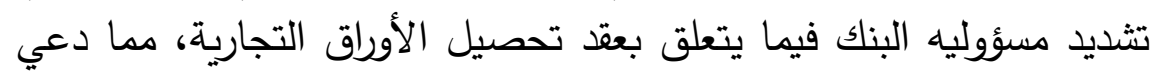

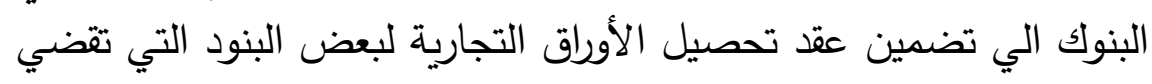


بإعفاء البنك من المسؤولية الناتجة عن اخلاله بالتزاماته عند تتفيذ عقد

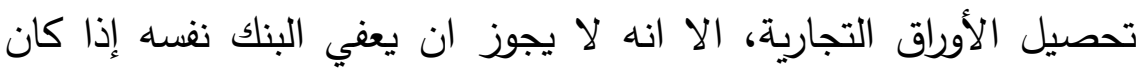

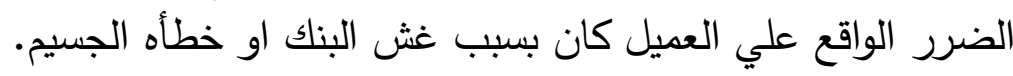
التوصيات:

توصلنا من خلال ما تم عرضه في أطروحتنا إلى التوصيات التالية:

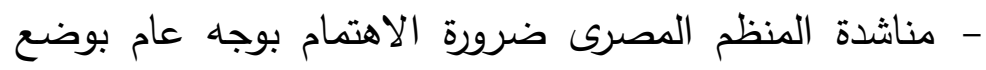

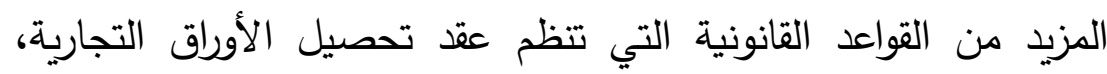

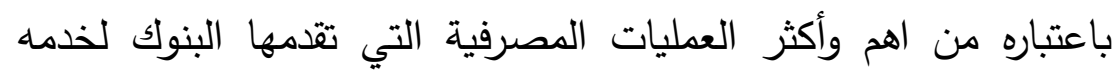
عمالأها.

- كما نناشد المنظم بضرورة النص صراحه على تأسيس المبا.

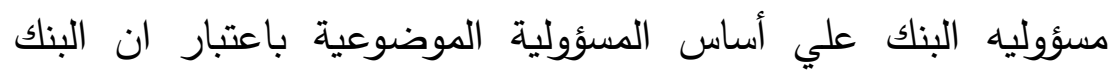

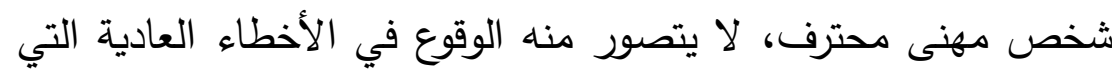
يقع فيها أي شخص عانى محترف، ليس لايه الخبرة والدراية المتوفرة للبنك.

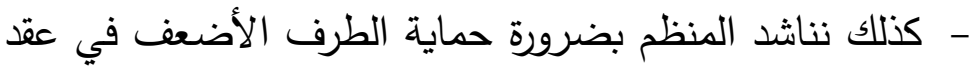
تحصيل الأوراق التجارية وهو العميل، وذلك من خلال وضع التع القوانين

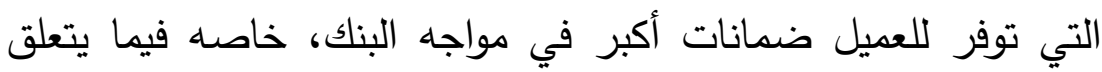
بتحديد وتضيق نطاق حالات اعفاء البنك من المسؤولية. 


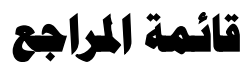

أولا: المراجيع العربية.

ا. إسماعيل غانم، النظرية العامة لالتزام، الجزء الثاني، مكتبه

عبد الله وهبه، بدون سنه طبع.

r. أمجد محمد منصور، النظرية العامة للالتزام، دار الثقافة للنشر

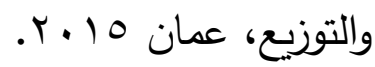

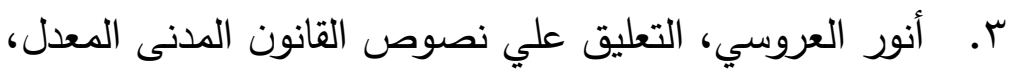

الجزء الثالث، دار المطبوعات الجامعية، الإسكندرية.

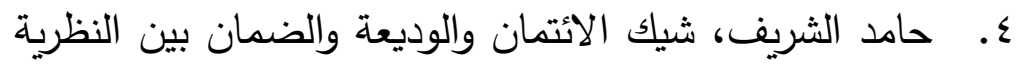

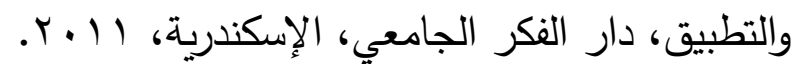

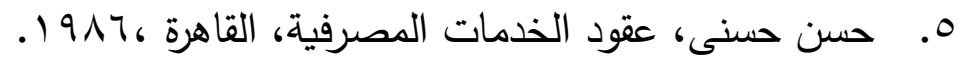

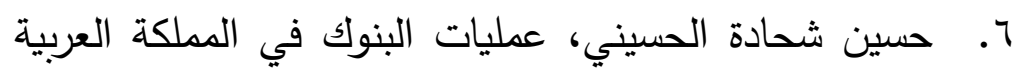

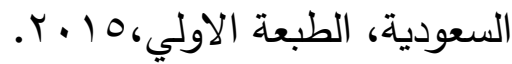

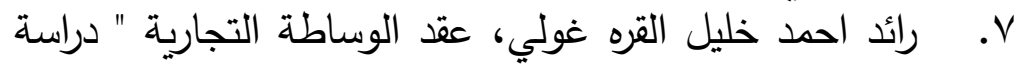

مقارنه"، المركز القومي للإصدارات القانونية، القاهرة، الطبعة الأولي، لإلئ

. $.1 \varepsilon$

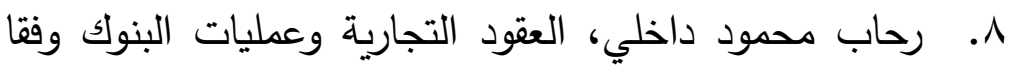

للنظام السعودي، مركز الدراسات العربية للنشر والتوزيع، القاهرة، الطبعة التبات

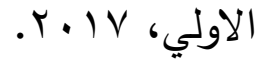

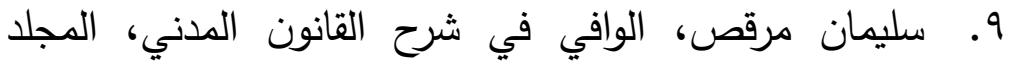

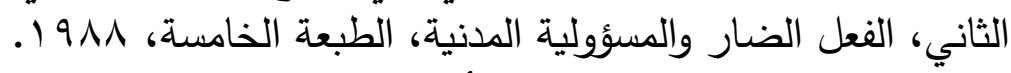

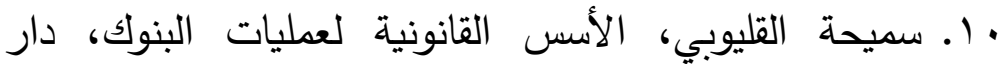

النهضة العربيه، 1999.

11. ال. عاشور عبد الجواد عبد الحكم، دور البنك في خدمة الأوراق

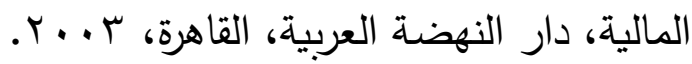

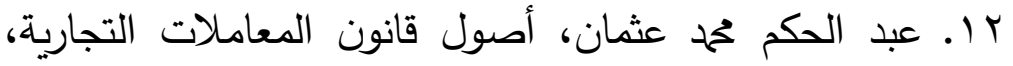

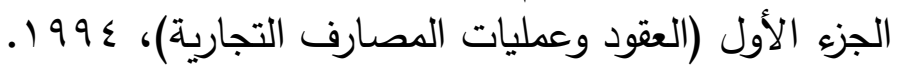

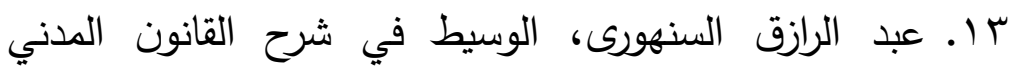

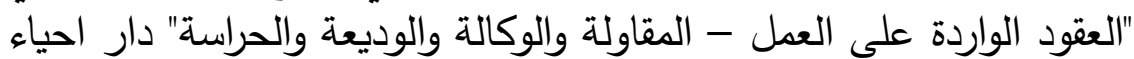

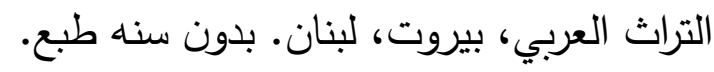

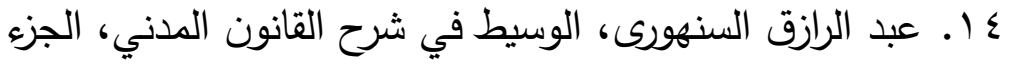

الثاني، دار النهضة العربية، القاهرة. 


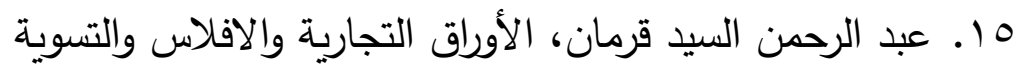

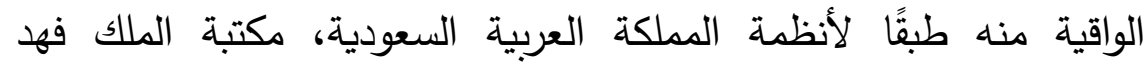

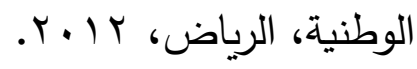
ا 1 . عبد الفتاح سليمان، استخدام الثيك ومشكلاته العملية وحلولها

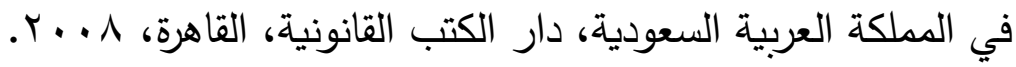

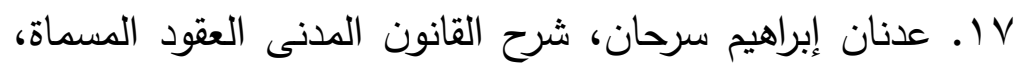

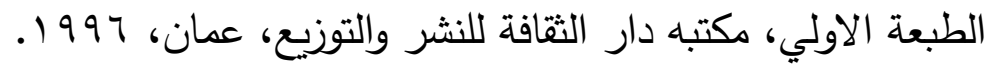

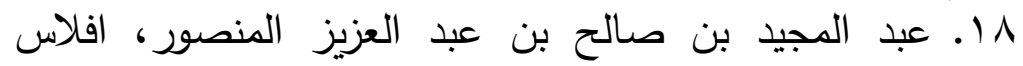

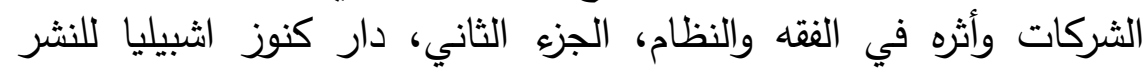

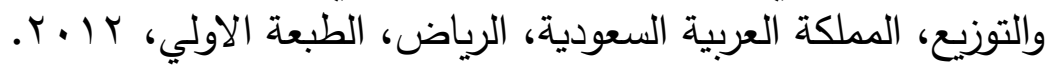

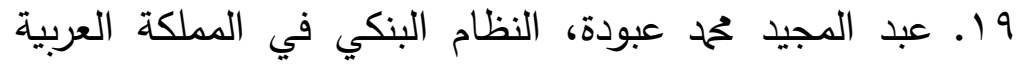

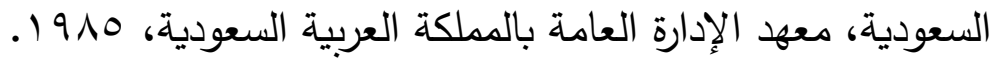

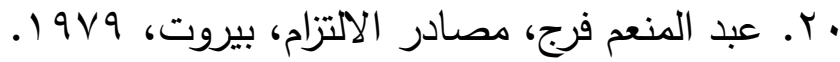

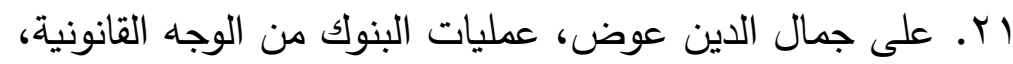

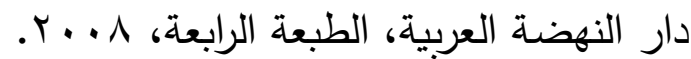
r.r. علي البارودى، العقود وعمليات البنوك التجارية، التبة، منشأه

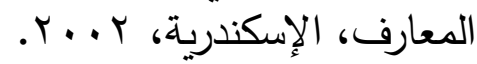

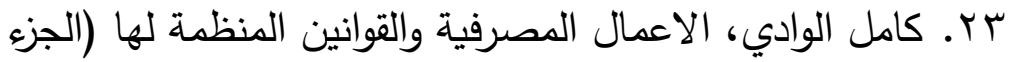

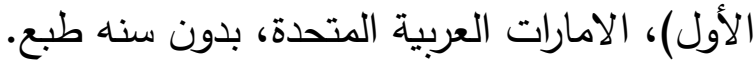

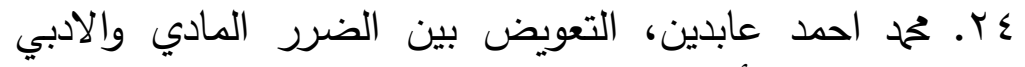

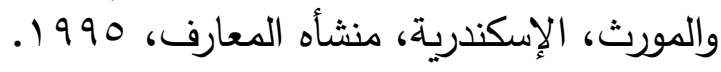

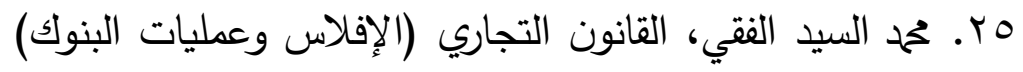

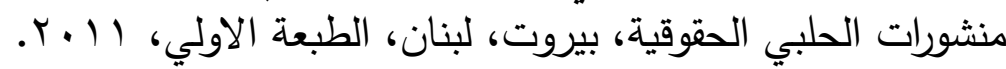

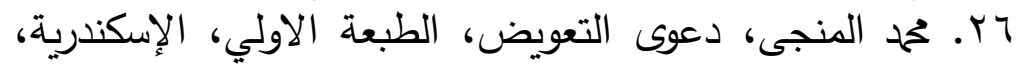
منشأه المعارف، . 199 19. rV

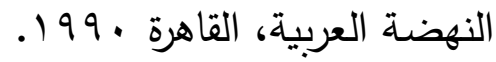

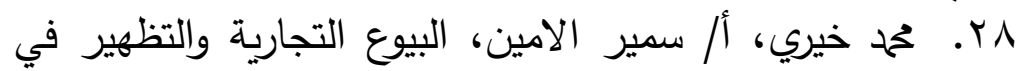

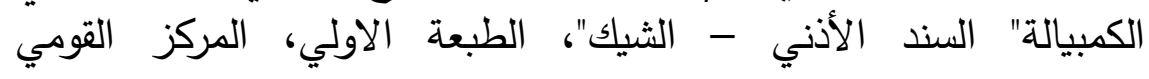

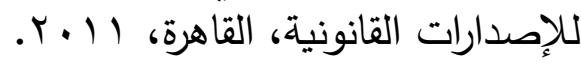
9r. محمود الكيلانى، عمليات البنوك، الجزء الأول، عمان، 
• ץ. محمود الكيلاني، الموسوعة التجارية والمصرفية (الأوراق

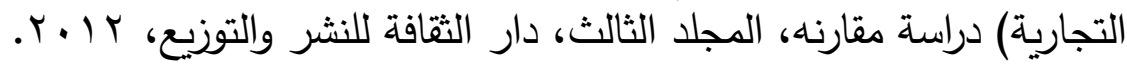

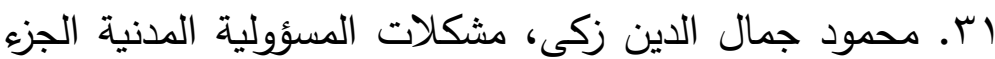

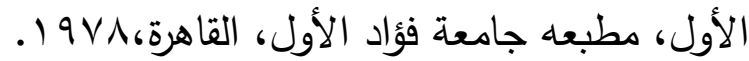

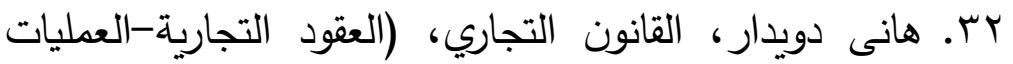

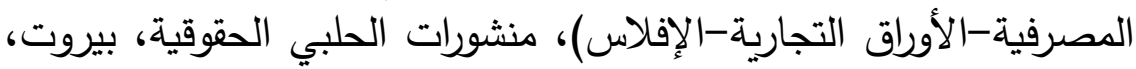

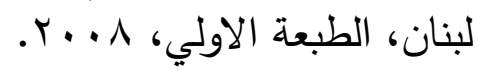

سr. وهبة الزحيلي، العقود المسماة في قانون المعاملات المدنية

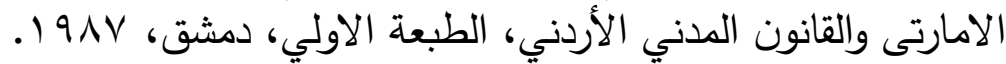

ثانيًا: الابحاث العلمية ورسيائل الاكتورياه.

- توريه توفيق، وكالة تحصيل وضمان الائ الحئوران الحقوق التجارية، رسالة دكتوراه،

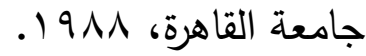

- غازى أبو العربي. بحث بعنوان "مسؤولية البنك العقدية عن عدم التمان

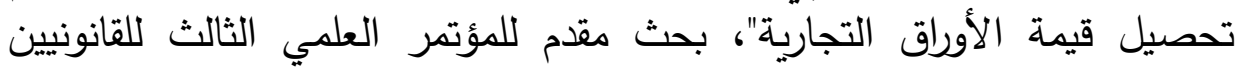

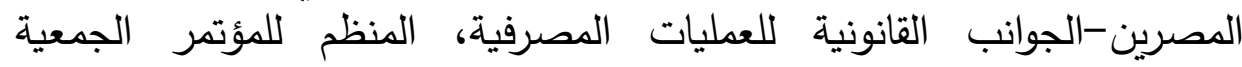

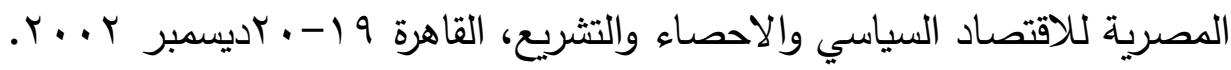

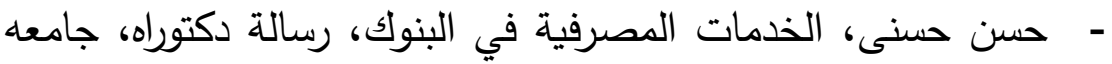
عين شمس.

- - مسين النوري، الكتمـان المصـرفي (اصـوله وفلسفته)، بحث منشـور

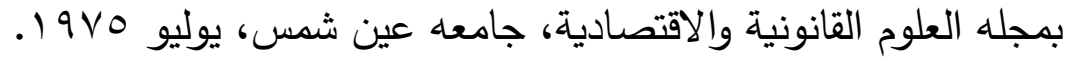
ثالثاً: المراجع الأجنبية.

\section{- ESSAM EL KALYOUBI, L'ENCAISSEMENT}

PAR LA BANQUE DES

CHEQUES ET EFFETS DE COMMERCE [Microforme, Paris, 1989.

- Fredericq, Louis, Dauge, Eugène,

Principes de droit commercial belge [Texte imprimé]. tome premier. Actes de commerce, commerçants vente,opérations de bourse gage et warrant, agents commerciaux : commissionnaires, courtiers, 
agents de change, représentants de commercepréposés, effets de commerce opérations de banque, chèques et comptes-courants,Paris, 1991.

- Ripert, Georges, Roblot, René , Delebecque, Philippe, Germain, Michel, Traité de droit commercial [Texte imprimé]. Tome 2. Valeurs mobilières, effets de commerce,Paris. 1998.

- Ripert, Georges, Roblot, René, Traité de droit commercial [Texte imprimé]. 2. Valeurs mobilières, effets de commerce, opérations de banque et debourse, contrats commerciaux, procédures collectives de redressement et de liquidation,Paris, 1976.

- VINEY.(G) Traite.de droit civil,Les obligations La responsbilite:conditions, L.G.D.J.paris.1982.

Buffelan.Lanore, Doroit, Civil, 3e edition. Masson. -paris .1986.

-Hamel, Joseph, Banques et opérations de banque.

Tome

second. Les dépôts et les virements. Les crédits de banque et leurs suretés. Les opérations sur effets de commerce, l'escompte. Aperçu sur le nouveau statut des banques françaisesm. Paris. 1962.

-Mallarmé, Victor, Des

Opérations de banque relatives aux effets de commerce, Université de Paris. Faculté de droit et des sciences économiques, Paris, 1987. 